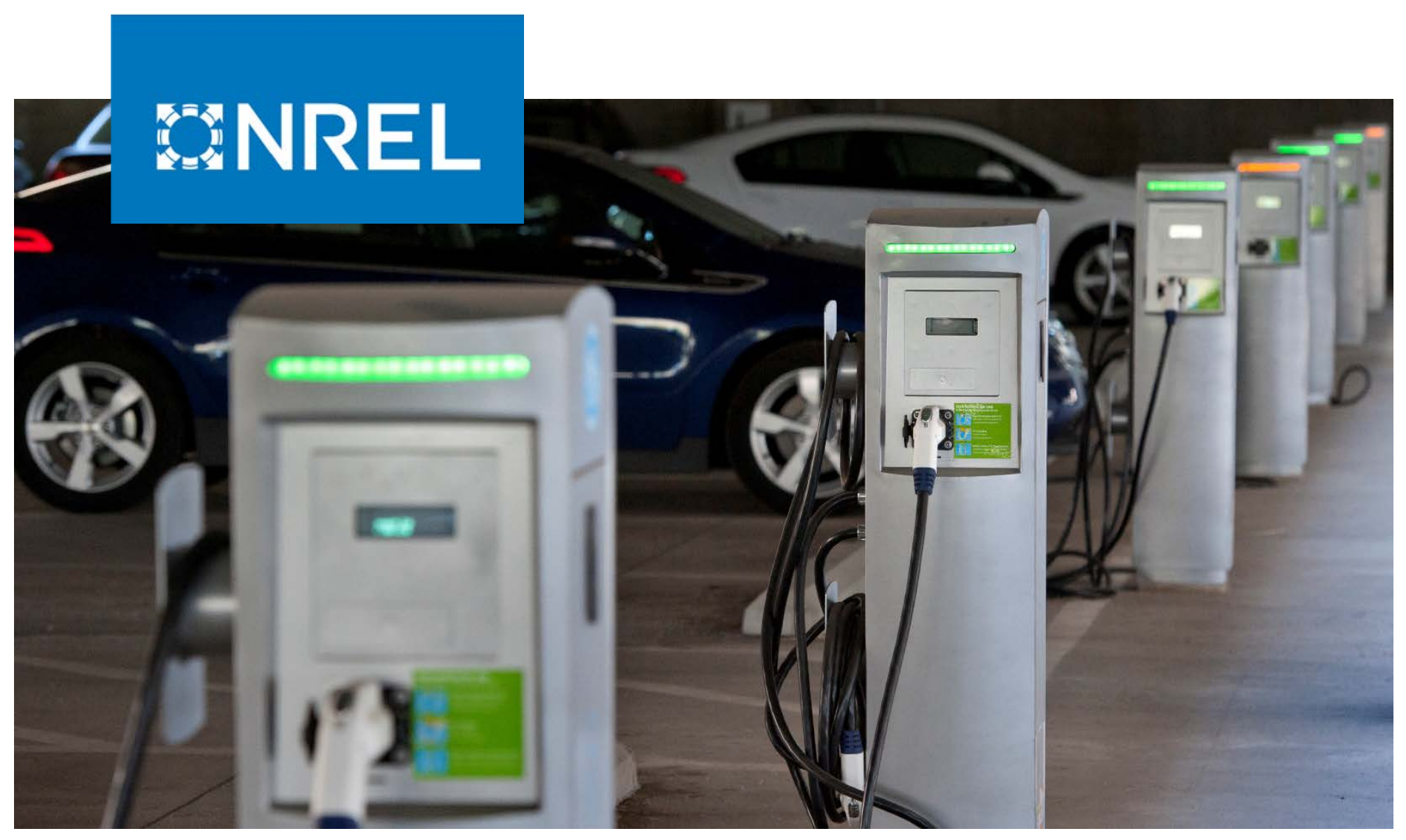

\title{
Electric Vehicle Supply Equipment Tiger Team Site Assessment Findings from Army Facilities
}

Jesse Bennett, Cabell Hodge, Chuck Kurnik, Kosol Kiatreungwattana, Lauren Lynch, and Jimmy Salasovich

National Renewable Energy Laboratory

Produced under direction of the U.S. Army by the National Renewable Energy Laboratory (NREL) under Interagency Agreement 18-2077.

NREL is a national laboratory of the U.S. Department of Energy Office of Energy Efficiency \& Renewable Energy

Operated by the Alliance for Sustainable Energy, LLC

This report is available at no cost from the National Renewable Energy Laboratory (NREL) at www.nrel.gov/publications.
Strategic Partnership Project Report NREL/TP-5400-74538

October 2019 


\section{BNREL}

\section{Electric Vehicle Supply Equipment Tiger Team Site Assessment Findings from Army Facilities}

Jesse Bennett, Cabell Hodge, Chuck Kurnik, Kosol Kiatreungwattana, Lauren Lynch, and Jimmy Salasovich

National Renewable Energy Laboratory

\section{Suggested Citation}

Bennett, Jesse, Cabell Hodge, Chuck Kurnik, Kosol Kiatreungwattana, Lauren Lynch, and Jimmy Salasovich. 2019. Electric Vehicle Supply Equipment Tiger Team Site Assessment Findings from Army Facilities. Golden, CO: National Renewable Energy Laboratory. NREL/TP-5400-74538. https://www.nrel.gov/docs/fy20osti/74538.pdf.

NREL is a national laboratory of the U.S. Department of Energy Office of Energy Efficiency \& Renewable Energy Operated by the Alliance for Sustainable Energy, LLC

This report is available at no cost from the National Renewable Energy Laboratory (NREL) at www.nrel.gov/publications.

Contract No. DE-AC36-08GO28308
Strategic Partnership Project Report NREL/TP-5400-74538 October 2019

National Renewable Energy Laboratory 15013 Denver West Parkway Golden, CO 80401 303-275-3000 • www.nrel.gov 


\section{NOTICE}

This work was authored by the National Renewable Energy Laboratory, operated by Alliance for Sustainable Energy, LLC, for the U.S. Department of Energy (DOE) under Contract No. DE-AC36-08GO28308. Funding provided by the U.S. Army under Interagency Agreement 18-2077. The views expressed herein do not necessarily represent the views of the DOE or the U.S. Government.

This report is available at no cost from the National Renewable Energy Laboratory (NREL) at www.nrel.gov/publications.

U.S. Department of Energy (DOE) reports produced after 1991 and a growing number of pre-1991 documents are available free via www.OSTI.gov.

Cover Photo by Dennis Schroeder: NREL 21661-C.

NREL prints on paper that contains recycled content. 


\section{Acknowledgments}

This work was supported by the U.S. Department of the Army under Interagency Agreement 18-2077 with the National Renewable Energy Laboratory (NREL). This report summarizes a package of electric vehicle supply equipment (EVSE) site assessments performed for the U.S. Army. Some of the language contained herein can be found in the original site reports by the authors of this overview report: Chuck Kurnik, Kosol Kiatreungwattana, Lauren Lynch, Jimmy Salasovich, Jesse Bennett, and Cabell Hodge.

Consultation with the U.S. Army Corps of Engineers (USACE), Department of Army Headquarters (HQDA), and garrisons was instrumental to the completion of this report. Eldric Jefferson, Josh Mason, Victor Petty, Keith Bridgeforth, Rebecca Hunt, and Rachel Hoeffner with USACE provided crucial input and support for site visits and reports. The authors are also grateful to the leadership provided from HQDA by Martin Brown, Jerry Winkler, Paul Malace, Rick Ballard, Dixie Smith, and Ed Moscatelli, and from the U.S. Department of Energy (DOE) Federal Energy Management Program (FEMP) by Tom Homan, Karen Guerra, and Brad Gustafson. Colleagues at NREL also provided invaluable insight, including John Gonzales, Margo Melendez, Kate Anderson, Mike Callahan, Adam Warren, Mark Singer, and Jerry Davis. Finally, the authors want to thank Heidi Blakley, Liz Breazeale, Jarett Zuboy, and other editors for their diligence, responsiveness, and attention to detail while editing these reports. 


\section{List of Acronyms}

$\begin{array}{ll}\text { A } & \text { amp } \\ \text { AC } & \text { alternating current } \\ \text { AFV } & \text { alternative fuel vehicle } \\ \text { BEV } & \text { battery electric vehicle } \\ \text { BPA } & \text { Blanket Purchase Agreement } \\ \text { CCS } & \text { Combined Charging System } \\ \text { CNG } & \text { compressed natural gas } \\ \text { DC } & \text { direct current } \\ \text { DCFC } & \text { DC fast charger } \\ \text { DOE } & \text { U.S. Department of Energy } \\ \text { DPW } & \text { Directorate of Public Works } \\ \text { EO } & \text { executive order } \\ \text { EPAct } 1992 & \text { Energy Policy Act of 1992 } \\ \text { EV } & \text { electric vehicle } \\ \text { EVSE } & \text { electric vehicle supply equipment } \\ \text { FEMP } & \text { Federal Energy Management Program } \\ \text { FY } & \text { Fiscal Year } \\ \text { GOV } & \text { government-owned vehicle } \\ \text { GSA } & \text { U.S. General Services Administration } \\ \text { HQ } & \text { Headquarters } \\ \text { HQDA } & \text { Department of Army Headquarters } \\ \text { kVA } & \text { kilovolt-ampere } \\ \text { LD } & \text { light-duty } \\ \text { LRC } & \text { Logistics Readiness Center } \\ \text { LSEV } & \text { low-speed electric vehicle } \\ \text { MDP } & \text { main distribution panel } \\ \text { NEC } & \text { National Electric Code } \\ \text { NGV } & \text { natural gas vehicle } \\ \text { NREL } & \text { National Renewable Energy Laboratory } \\ \text { OACSIM } & \text { Office of the Assistant Chief of Staff for Installation Management } \\ \text { PHEV } & \text { plug-in hybrid electric vehicle } \\ \text { POV } & \text { personally owned vehicle } \\ \text { RFID } & \text { radio frequency identification } \\ \text { SAE } & \text { Society of Automotive Engineers } \\ \text { SUV } & \text { sport utility vehicle } \\ \text { TMP } & \text { transportation motor pool } \\ \text { USACE } & \text { U.S Army Corps of Engineers } \\ \text { V } & \text { volt } \\ & \end{array}$




\section{Executive Summary}

This report examines how the U.S. Army can cost-effectively install electric vehicle supply equipment (EVSE) to prepare for anticipated electric vehicle (EV) acquisitions, and summarizes results from 30 EVSE site visits completed at U.S. Army garrisons from 2016-2019. Sponsored by the U.S. Department of Energy (DOE) and U.S. Army, the National Renewable Energy Laboratory (NREL) deployed Tiger Teams consisting of engineers and fleet experts to review garrison charging needs and develop recommendations for installing EVSE as well as compressed natural gas $(\mathrm{CNG})$ stations in certain locations.

From these 30 site visits, the Tiger Teams recommended the installation of 252 EVSE to support the planned short-term acquisition of 236 fleet EVs and an undetermined number of additional fleet acquisitions. The planned fleet EVs would account for $17 \%$ of the participating fleet's sedans and station wagons, and 3\% of their entire light duty fleet, suggesting a sizeable impact as well as opportunities for continued expansion. While the General Services Administration (GSA) was limited by commercial availability to leasing sedan and station wagon EV options in 2016, by 2019, GSA began offering crossover, sport utility, and minivan electric options on its standard offering schedule as well as a cargo van through GSA Advantage.

In a few locations, the Tiger Teams assessed the potential to support Army bus fleets with onbase CNG stations. NREL sent a gaseous fuels expert to Fort Jackson, where Army wanted to prioritize a CNG station to serve troop transport trucks. Other garrisons expressed interest in $\mathrm{CNG}$, but the NREL recommendations at those locations were less specific.

Throughout the project, the Tiger Teams recommended EVSE installations that will enable a smooth transition for EV acquisitions anticipated in the next three to five years. In addition to supporting near-term plans, NREL delivered site assessment reports to each location with lessons that will assist with a longer-term, large-scale transition to EVs. This transition will improve fleet efficiency and help reduce petroleum consumption, fueling costs, and vehicle maintenance. 


\section{Table of Contents}

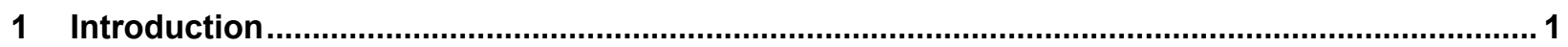

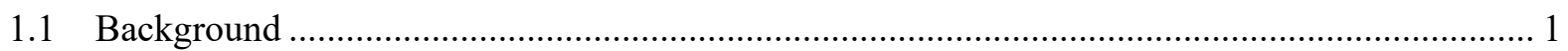

1.2 Regulatory History and Market Developments ............................................................... 2

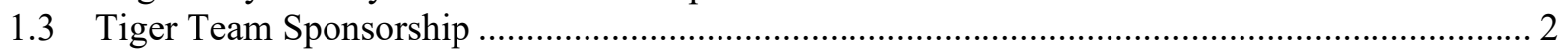

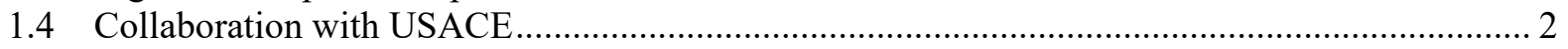

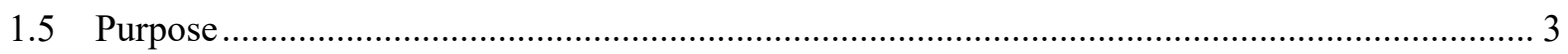

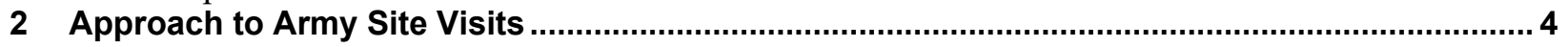

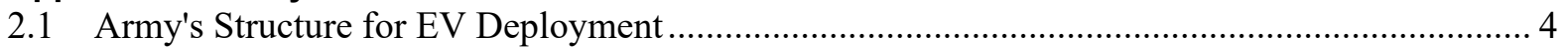

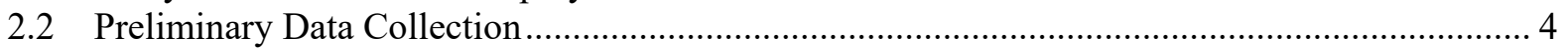

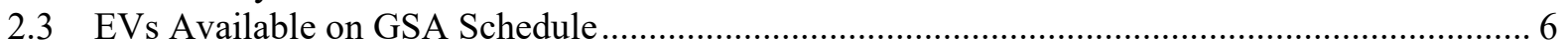

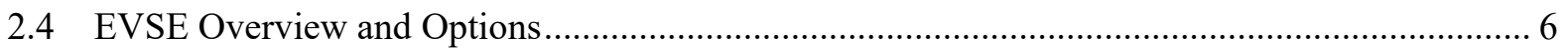

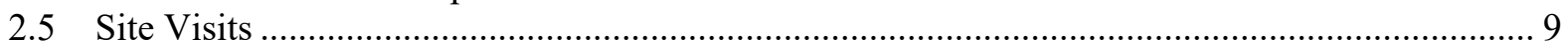

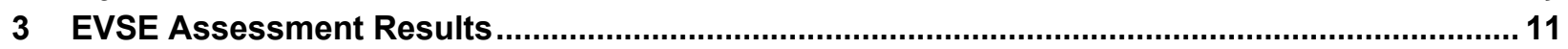

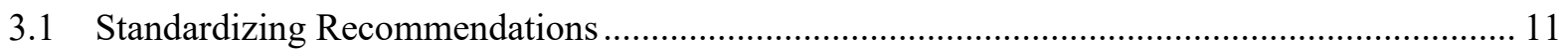

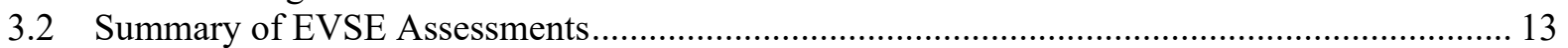

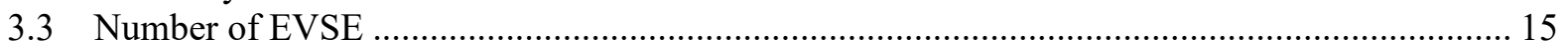

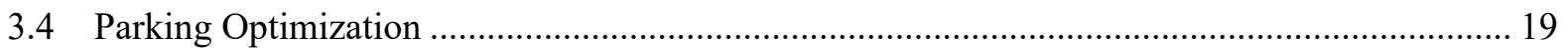

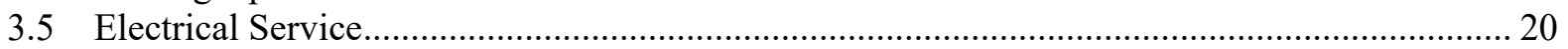

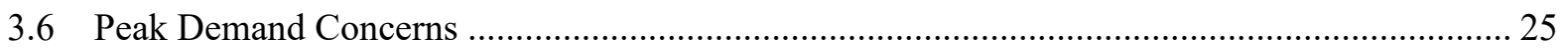

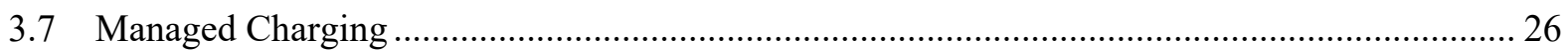

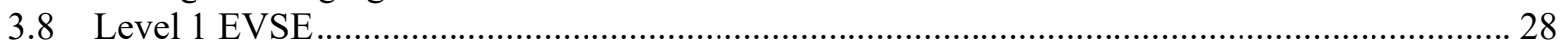

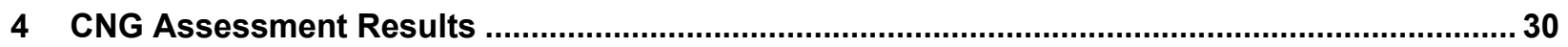

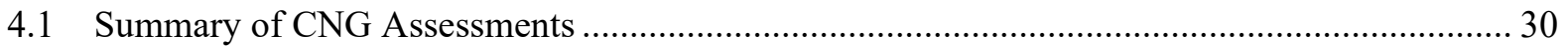

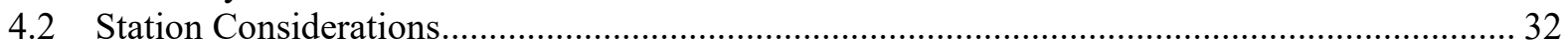

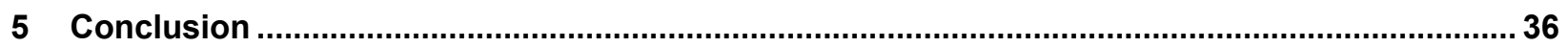

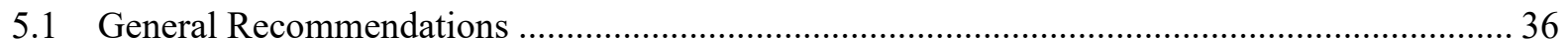

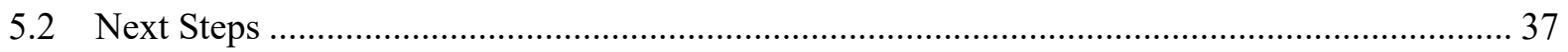

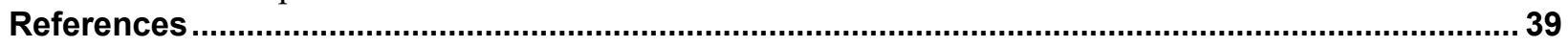

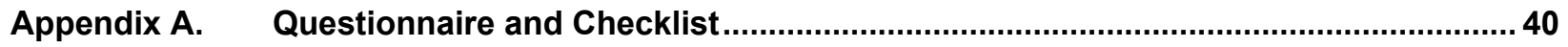

Appendix B. List of Tiger Team Site Assessment Recommendations ......................................42 


\section{List of Figures}

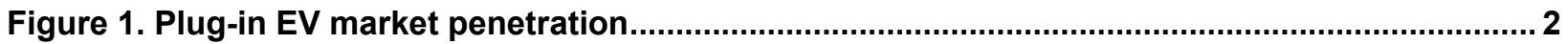

Figure 2. Garrison fleets visited as a proportion of total covered LD Army vehicles ....................... 5

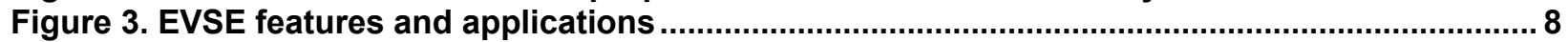

Figure 4. EV at Adelphi Laboratory Center connected to 120-V outlet ......................................... 10

Figure 5. Recommended location of EVSE in Fort Jackson TMP based on transformer proximity 12

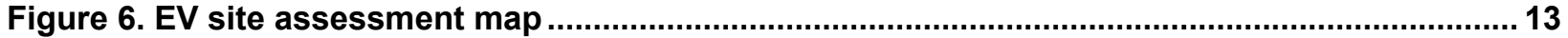

Figure 7. Fort McCoy TMP general layout with expansion ......................................................... 16

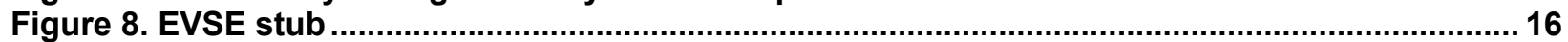

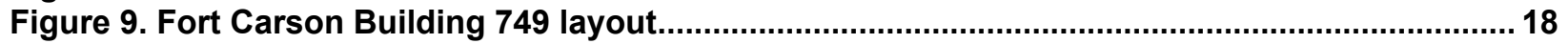

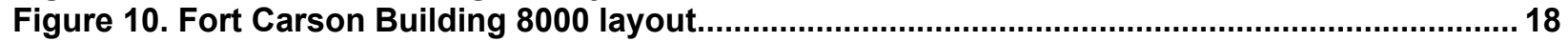

Figure 11. Reserved parking spaces for special use ...................................................................... 19

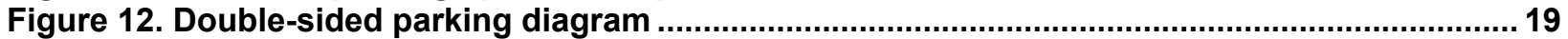

Figure 13. Options for EVSE installation at Fort Leonard Wood ................................................. 20

Figure 14. Overhead transformer connection at Fort AP Hill ........................................................ 21

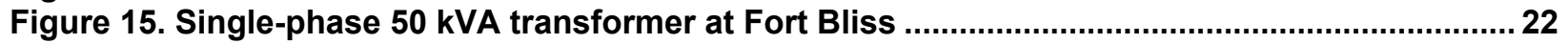

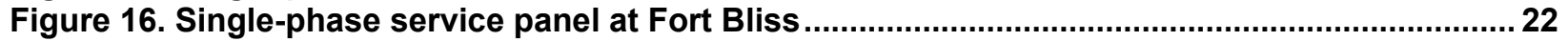

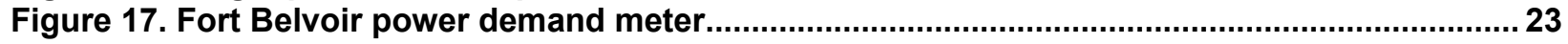

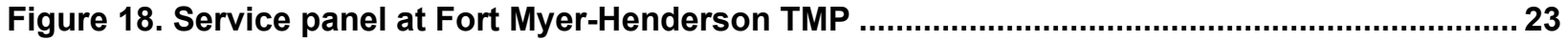

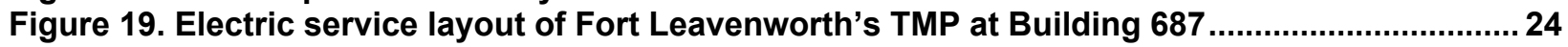

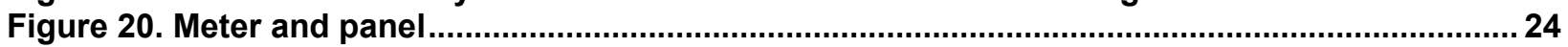

Figure 21. Recommended EVSE installation at Fort Riley....................................................... 25

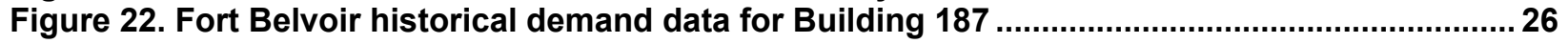

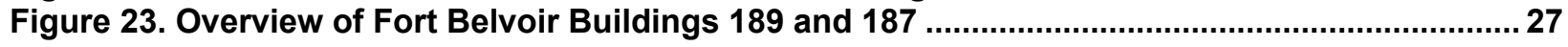

Figure 24. Level 1 receptacle at Fort A.P. Hill ....................................................................... 28

Figure 25. Dedicated parking space with existing Level 1 at North Fort Hood TMP ........................29

Figure 26. TMP yard and high-pressure gas location at Fort Jackson .......................................... 30

Figure 27. CNG station blueprint at Fort Jackson ...................................................................... 31

Figure 28. TMP aerial view with CNG station location recommendations .......................................... 32

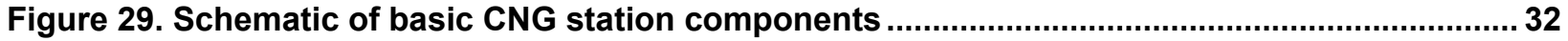

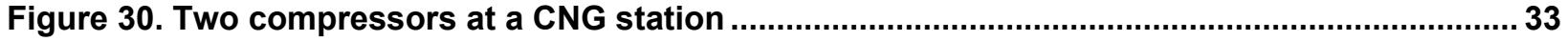

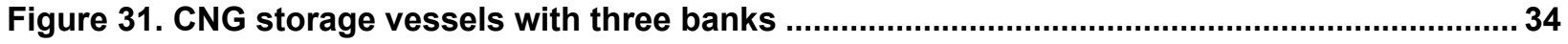

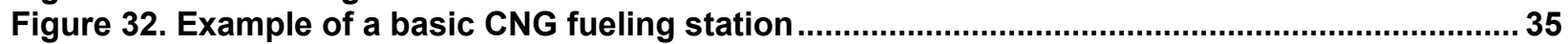

\section{List of Tables}

Table 1. Army 2018 Covered LD Vehicle Inventory ......................................................................... 5

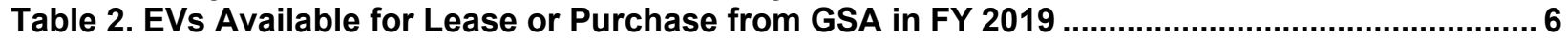

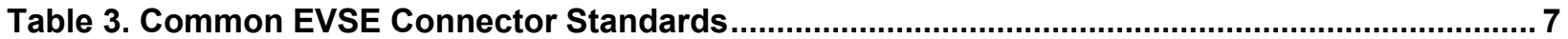

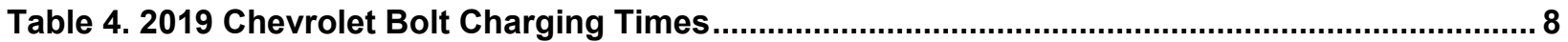

Table 5. Service Panel Considerations for EVSE ….................................................................... 11

Table 6. Garrison Planned EV Acquisitions and EVSE Recommendations....................................14

Table 7. EVSE Infrastructure Options for the TMP at Fort McCoy Buildings 1884 and $1887 \ldots \ldots . . . . .17$

Table 8. EVSE Infrastructure Options for the TMP at Fort Carson Buildings 749 and 8000 ............. 18

Table 9. EVSE Infrastructure Options for the TMP at Fort Leavenworth Building $687 \ldots \ldots \ldots \ldots \ldots \ldots . . . . . . . .24$

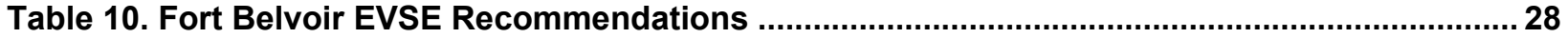




\section{Introduction}

This report amalgamates results from 30 site visits completed at U.S. Army garrisons from 2016-2019 to evaluate opportunities and feasibility for the installation of electric vehicle supply equipment (EVSE). Through sponsorship from the U.S. Department of Energy (DOE) for the initial sites and the U.S. Army for the majority of garrisons, the National Renewable Energy Laboratory (NREL) deployed Tiger Teams consisting of engineers and fleet experts to review site charging needs and develop recommendations for installing EVSE.

\subsection{Background}

To ensure the U.S. Army is in compliance with statutes and internal policies concerning alternative fuel vehicles, the Army plans to integrate both electric and natural gas vehicles into their fleet. This process will focus on electric vehicle (EV) technology by acquiring an assortment of battery electric vehicles (BEVs), plug-in hybrid electric vehicles (PHEVs), and hybrid electric vehicles (HEVs). The Army has plans to purchase and install EVSE in phases based on installation location, non-tactical vehicle density, and vehicle mission, In locations where there is a strong focus on medium-duty or heavy-duty vehicles, in which there are currently no viable EVs, the Army is exploring natural gas vehicles (NGVs) supported by compressed natural gas $(\mathrm{CNG})$ fueling stations.

Prior to purchase and installation of EVSE or CNG stations, the Department of Army Headquarters deployed EVSE Tiger Teams to conduct site analyses. The Tiger Teams visiting Army garrisons in 2018 and 2019 included representatives from the U.S. Army Corps of Engineers (USACE) and NREL working under the direction of the Department of the Army Headquarters (HQDA). The teams visited sites prioritized by HQDA for the installation of EVSE. The Tiger Teams then provided their recommendations on the installation of EVSE or CNG stations to minimize costs while accommodating the long-term charging or fueling needs of the fleet.

Both EVs and NGVs can reduce operational costs compared to gasoline and diesel vehicles through lower fuel and maintenance costs. They can also improve resilience by diversifying fuel sources and, in the case of some PHEVs, extending vehicle range to over 600 miles. EVSE is more compact and modular than conventional fueling stations, allowing it to be installed within parking lots where vehicles are housed, improving driver convenience in many cases. Furthermore, EVs and NGVs help the Army to comply with multiple regulatory mandates, including alternative fuel vehicle (AFV) acquisition requirements. 


\subsection{Regulatory History and Market Developments}

In 2015, Executive Order (EO) 13693 created a trajectory for agencies to acquire zero-emissions vehicles (including BEVs and PHEVs) in numbers equivalent to $20 \%$ of passenger vehicle acquisitions by 2020 and 50\% by 2025. In May 2018, EO 13834 revoked EO 13693 and replaced it with language encouraging agencies to "meet statutory requirements in a manner that increases efficiency, optimizes performance, eliminates unnecessary use of resources, and protects the environment." Examining the federal fleet statutory framework, the Energy Policy Act of 1992 (EPAct 1992) requires agencies to acquire AFVs in numbers equivalent to $75 \%$ of covered lightduty (LD) acquisitions on an annual basis. As the U.S. Army and other federal agencies strive to comply with EPAct 1992 requirements, many are transitioning to EVs from a heavier focus on biofuels, including ethanol flex-fuel vehicles. This transition is a result of the Army fleet responding to market forces and ensures the Army is able to take advantage of the benefits of EVs as they become more prevalent. In 2018, plug-in EV sales as a percentage of total U.S. car sales grew to nearly $6 \%$, more than doubling 2017 market penetration (Figure 1) (Argonne National Laboratory 2019).

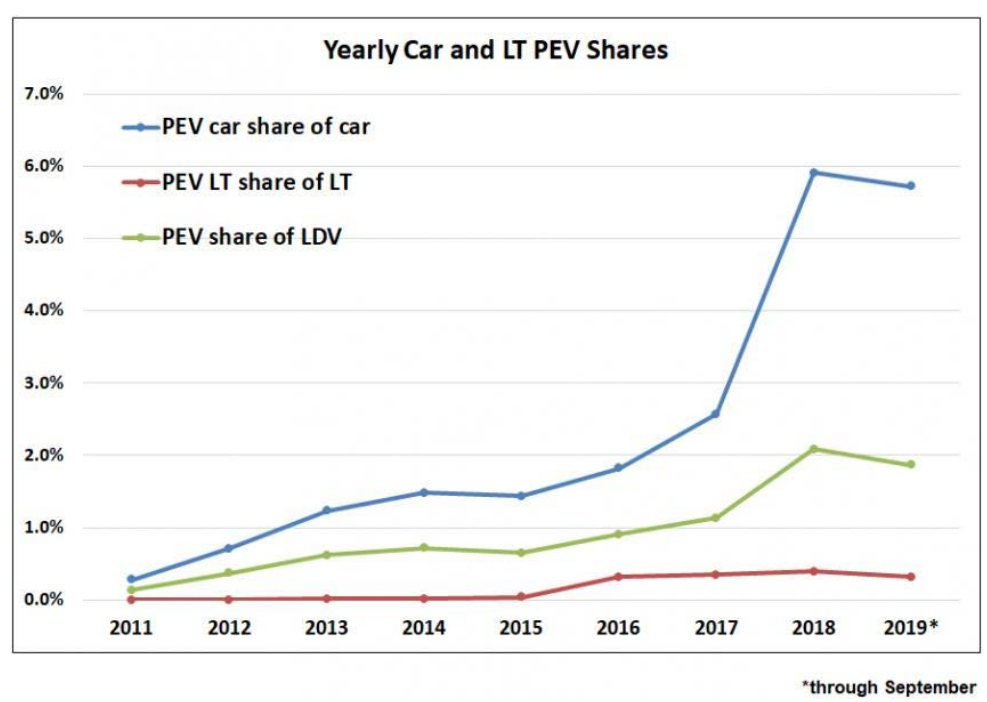

Figure 1. Plug-in EV market penetration

Figure credit: Argonne National Laboratory 2019

\subsection{Tiger Team Sponsorship}

The DOE Federal Energy Management Program (FEMP) operates a regulatory and technical assistance program for federal agency fleets that includes oversight of the EPAct 1992 requirement to acquire AFVs. FEMP pioneered the EVSE Tiger Team approach in 2016 by sponsoring visits from NREL to five Navy bases in the southwestern United States. FEMP funded an additional 12 site visits over the next two years, including five Army garrisons. In the process, NREL and the Army refined their approach to site visits as described in Section 2. In 2018, the Army engaged NREL, in collaboration with the USACE, to complete 25 more site visits with accompanying reports in addition to this overarching analysis.

\subsection{Collaboration with USACE}

USACE assisted in all site visits and reports where they provided invaluable support to the site assessment, recommendations and implementation of the recommendations to concept plans. USACE completed conceptual designs and statements of work while serving as the Army's prime contractor, subcontracting to NREL to author the site reports. USACE, NREL engineers, and project managers jointly visited each location, where they worked with representatives from the garrison Logistics Readiness Centers (LRCs) and Directorates of Public Works (DPWs) to identify optimal locations for EVSE units. 


\subsection{Purpose}

The Tiger Teams were deployed to help fleet and facility managers plan for the installation of EVSE. By discussing acquisition plans for government-owned vehicles (GOVs), workplace charging needs for personally owned vehicles (POVs), then reviewing parking locations and electrical infrastructure, the Tiger Teams developed recommendations for numbers, types, and locations of EVSE necessary to support the garrisons in coming years. 


\section{Approach to Army Site Visits}

The approach to Army site visits was guided by HQDA prioritization of electrifying vehicles in transportation motor pools (TMPs), followed by other fleet GOVs, and finally POV parking areas. Garrison needs, background, and rules strongly informed the approach at each location within the greater HQDA process. NREL and USACE attempted to standardize the reports by asking garrisons to provide specific information in advance of the visits, reviewing their existing vehicle inventories, arranging kickoff meetings with personnel from the site LRCs and DPWs, and taking a prescribed approach to the on-site assessments. NREL collaborated with utilities at several sites directly or through LRC and DPW staff.

\subsection{Army's Structure for EV Deployment}

The Office of the Assistant Chief of Staff for Installation Management (OACSIM) has oversight authority for the Army's fleet vehicles and TMPs, and it has prioritized the acquisition of BEVs, PHEVs, and HEVs based on regulatory drivers and market developments. To support the BEVs and PHEVs, OACSIM is purchasing and installing EVSE in phases based on installation location, non-tactical vehicle density, and vehicle mission. To inform the installation of EVSE, OACSIM deployed Tiger Teams to review high-priority sites, draft reports, and develop conceptual designs to best serve the garrisons electric fleet vehicle needs. OACSIM directed the Tiger Teams to develop recommendations for installing Level 2 EVSE based on the charging needs of its fleet (and POVs where applicable).

\subsection{Preliminary Data Collection}

In preparation for each site visit, the Tiger Teams reviewed available fleet vehicle inventory data and submitted a questionnaire to each LRC and DPW in hopes of acquiring site-specific data relating to the electrical infrastructure, current use and future needs of the electric vehicles. This supplemental data was reviewed with each location at the beginning of the site visit during an introductory kickoff meeting.

\subsubsection{Questionnaire and Checklist}

NREL developed a questionnaire for garrisons to complete and a checklist for data to provide prior to the site visits. The questionnaire and checklist were provided to collect information on the four topics below.

1. Anticipated fleet EV acquisitions

2. EVSE location plan and electrical input

3. Employee POV charging

4. General considerations impacting EVSE needs

The checklist provided a way for garrisons and NREL to properly prepare for site visits by determining which parking areas to visit and electrical service to examine as well as gathering details about the utility providing the service. It included items such as marked-up parking area maps indicating potential locations for EVSE and power calculations. Both the questionnaire and checklist are provided in Appendix A. 


\subsubsection{Vehicle Inventory}

The Army reports vehicle inventory in the Federal Automotive Statistical Tool at year's end. The inventory notes the vehicle identifier, make, model, fuel type, model year, and location, as well as annual vehicle miles traveled and fuel consumption. This information was used to identify prospective candidates for electrification. Every December, each installation receives a list of vehicles that are due for replacement. This is an opportunity to acquire more BEVs, PHEVs, and HEVs for its fleet. The team focused on LD vehicles with available replacement vehicles through the U.S. General Services Administration (GSA). The Army reported 30,286 active LD vehicles in 2018 out of 55,770 domestic, non-tactical vehicles (excluding law enforcement and emergency response vehicles in both cases) (Table 1). Of those, 9,237 were pickup trucks for which an identical EV replacement does not yet exist; however, most of the remaining 21,049 LD vehicles are sedans, station wagons, minivans, or sport utility vehicles (SUVs) with suitable replacements available through GSA. The Army reported 495 EVs in 2018, which represents a current adoption rate of $1.6 \%$ of covered LD vehicles.

Table 1. Army 2018 Covered LD Vehicle Inventory

\begin{tabular}{lc}
\hline Vehicle Class & Number of Vehicles \\
\hline LD $4 \times 2$ & 11,840 \\
LD $4 \times 4$ & 6,345 \\
Sedans and Station Wagons & 12,101 \\
\hline Total LD Vehicles & $\mathbf{3 0 , 2 8 6}$ \\
\hline
\end{tabular}

The Army reported 495 EVs in 2018, which represents a current adoption rate of $1.6 \%$ of covered LD vehicles. The garrisons visited by Tiger Teams included 7,813 LD vehicles, approximately $26 \%$ of Army's covered LD vehicle inventory (Figure 2).

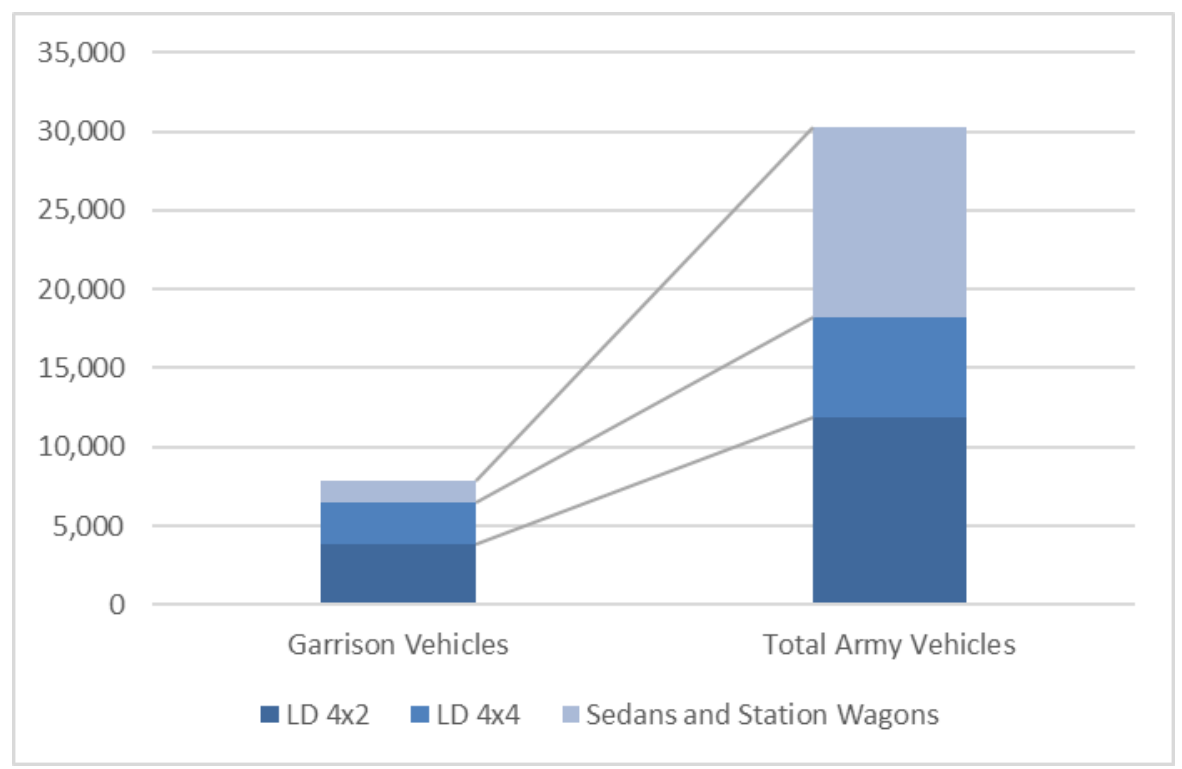

Figure 2. Garrison fleets visited as a proportion of total covered LD Army vehicles 


\subsection{EVs Available on GSA Schedule}

The Army typically leases sedans and other LD vehicles from GSA. For Fiscal Year (FY) 2019, GSA has offered eight LD EVs, including sedans and hatchbacks of different sizes and fuel configurations, a PHEV minivan, a PHEV crossover, and a four-wheel-drive PHEV SUV (Table 2). The longest-range BEV, the Chevrolet Bolt, is listed with an EPA-rated range of 238 miles. GSA also offers six PHEVs with all-electric ranges of 22-32 miles, with an average range of 538 miles in hybrid mode.

Table 2. EVs Available for Lease or Purchase from GSA in FY 2019

\begin{tabular}{|c|c|c|c|c|c|c|c|c|}
\hline Make & Model & Size & $\begin{array}{l}\text { EV } \\
\text { Type }\end{array}$ & $\begin{array}{r}\text { Range } \\
\text { Electric/ } \\
\text { Total } \\
\text { (miles) }\end{array}$ & $\begin{array}{r}\text { Purchase } \\
\text { Price }\end{array}$ & $\begin{array}{r}\text { Monthly } \\
\text { Rate }\end{array}$ & $\begin{array}{r}\text { Mileage } \\
\text { Rate } \\
\text { (\$/mile) }\end{array}$ & $\begin{array}{r}\text { Incremental } \\
\text { Cost }^{2}\end{array}$ \\
\hline Hyundai & Ioniq & Subcompact & PHEV & $29 / 630$ & $\$ 21,411$ & $\$ 195$ & $\$ 0.088$ & $\$ 7,902$ \\
\hline Nissan & Leaf & Subcompact & BEV & 151 & $\$ 29,642$ & $\$ 195$ & $\$ 0.054$ & $\$ 16,134$ \\
\hline Chevrolet & Bolt & Subcompact & BEV & 238 & $\$ 32,320$ & $\$ 195$ & $\$ 0.054$ & $\$ 18,811$ \\
\hline Hyundai & Sonata & Compact & PHEV & $28 / 600$ & $\$ 26,870$ & $\$ 216$ & $\$ 0.099$ & $\$ 9,863$ \\
\hline Ford & Fusion & Compact & PHEV & $26 / 610$ & $\$ 27,647$ & $\$ 216$ & $\$ 0.099$ & $\$ 10,639$ \\
\hline Kia & Niro & Crossover & PHEV & $26 / 560$ & $\$ 24,043$ & TBD & $\$ 0.101$ & $\$ 5,317$ \\
\hline Mitsubishi & Outlander & SUV $4 \times 4$ & PHEV & $22 / 310$ & $\$ 31,531$ & $\$ 319$ & $\$ 0.144$ & $\$ 9,811$ \\
\hline Chrysler & Pacifica & Minivan & PHEV & $32 / 520$ & $\$ 40,072$ & $\$ 263$ & $\$ 0.129$ & $\$ 19,367$ \\
\hline
\end{tabular}

The fuel reimbursement structure for EVs on the GSA schedule is different than for other vehicle types. GSA pays for gasoline and other fuel as part of the mileage rate; however, GSA discounts the mileage rate for EVs because it does not reimburse the fuel costs. For a subcompact BEV, GSA charged \$0.054/mile in 2019 to account for maintenance and fleet management services, significantly less than the cost of $\$ 0.123 /$ mile for a subcompact gasoline sedan, which would include fuel. All EVs on the GSA schedule cost more than the lowest-priced option in the same vehicle class. This price differential is accounted for by the incremental cost, as shown in Table 2.

\subsection{EVSE Overview and Options}

EVs can be charged with alternating current (AC) or direct current (DC) EVSE. The AC EVSE units are classified as Level 1, based on a supply of 120 volts (V), or as Level 2, with 208-240 V. They follow the Society of Automotive Engineers (SAE) J1772 standard for interface requirements, allowing for the interchange of basic communication to set charging current limits and ensuring the EV charge cord is only energized when connected to a vehicle (Table 3 ).

Level 1 EVSE typically includes portable charging cord sets that plug into a standard $120 \mathrm{~V}$ wall outlet. These EVSE units provide 10-12 amps (A) of charging current, based on the lower of the EVSE and EV onboard charger ratings. Stand-alone Level 1 units are similar in appearance to Level 2 EVSE and can provide up to 16 A of charging current. 
Level 2 EVSE typically includes permanently mounted charging stations that use a hard-wired connection but can also use a $208 \mathrm{~V}$ or $240 \mathrm{~V}$ wall outlet. These EVSE units provide up to $80 \mathrm{~A}$ of charging current, based on the lower of the EVSE and EV onboard charger ratings, but are typically rated from 16-32 A.

DC fast chargers (DCFCs) have three existing standards in the United States: J1772 Combined Charging System (CCS), CHAdeMO, and Tesla Supercharger. These chargers convert AC to DC and provide the $\mathrm{DC}$ charging current to the $\mathrm{EV}$, based on its charge request. These units are permanently mounted charging stations and are typically supplied with three-phase AC power at 208/480 V with $50 \mathrm{~kW}$ or more of charging power.

Table 3. Common EVSE Connector Standards

\begin{tabular}{lccccc}
\hline Connector & SAE J1772 & SAE J1772 & CHAdeMO & Tesla \\
\hline $\begin{array}{l}\text { Maximum Power } \\
\text { Delivery (kW) }\end{array}$ & Level 1 & Level 2 & 400 & 400 & 145 \\
& 1.92 & 19.2 & & & \\
Port Appearance $^{\text {a }}$ & & 0 & 0 &
\end{tabular}

As an example, the 2019 Chevrolet Bolt BEV is capable of AC Level 1, AC Level 2, and DC J1772 CCS charging. The maximum AC charging power for Level 1 is $1.92 \mathrm{~kW}$ with $16 \mathrm{~A}$ charging. Level 2 charging is limited by the onboard rectifier power of $7.2 \mathrm{~kW}$ or the current rating of the Level $2 \mathrm{EVSE}$ - which must be $35 \mathrm{~A}$ for a $208 \mathrm{~V}$ system to reach the $7.2 \mathrm{~kW}$ rating of the vehicle. The website for the 2019 Chevrolet Bolt (Chevrolet n.d.) states that Level 1 provides about four miles of range per hour of charging, and a 32 A Level 2 charge provides about 25 miles per hour of charging. DC J1772 CCS charging adds about 180 miles per hour of charging. DCFC is not recommended for the fleet at this time. First, a DCFC is an order of magnitude more expensive than a Level 2 charger and will likely require electrical infrastructure upgrades, such as new transformers and conductors. Second, using only DCFC to charge EVs reduces battery life, given the current state of battery technology. Level 2 provides the optimal charge rate for most Army fleet vehicles, and DCFC should only be used when needed on a longer trip. Table 4 provides charging-time estimates for different AC-charging scenarios. 
Table 4. 2019 Chevrolet Bolt Charging Times

\begin{tabular}{|c|c|c|c|c|c|c|c|}
\hline EVSE Type & $\begin{array}{r}\text { Voltage } \\
\text { (V) }\end{array}$ & $\begin{array}{r}\text { Current } \\
\text { (A) }\end{array}$ & $\begin{array}{r}\text { Charging } \\
\text { Power (kW) }\end{array}$ & $\begin{array}{r}\text { Maximum } \\
\text { Vehicle-Rated } \\
\text { Charging } \\
\text { Power }(k W)^{\mathrm{a}}\end{array}$ & $\begin{array}{r}\text { Vehicle } \\
\text { Efficiency } \\
(\mathrm{kWh} / \mathrm{mile})^{\mathrm{b}}\end{array}$ & $\begin{array}{r}\text { Charge } \\
\text { Rate } \\
(\mathrm{mile} / \mathrm{hr})^{\mathrm{c}}\end{array}$ & $\begin{array}{r}\text { Full } \\
\text { Charge } \\
\text { Time }(\mathrm{hr})^{\mathrm{c}}\end{array}$ \\
\hline AC Level 1 & 120 & 12 & 1.4 & 7.2 & 0.28 & 4.8 & 49.8 \\
\hline AC Level 2 at $32 \mathrm{~A}$ & 208 & 32 & 6.7 & 7.2 & 0.28 & 22.1 & 10.8 \\
\hline AC Level 2 at $16 \mathrm{~A}$ & 208 & 16 & 3.3 & 7.2 & 0.28 & 11.1 & 21.5 \\
\hline $\begin{array}{l}\text { a. } \text { Rated charger powe } \\
\text { b. } 2019 \text { Chevrolet Bolt } \\
\text { c. Charge rate and full }\end{array}$ & $\begin{array}{l}\text { Chevrole } \\
\text { ined U.S. } \\
\text { e time are }\end{array}$ & $\begin{array}{l}\text { 18). } \\
\text { onmenta } \\
\text { ulated wi }\end{array}$ & $\%$ pen & t for battery & $\begin{array}{l}\text { my.gov (2018). } \\
\text { and taper chargi }\end{array}$ & & \\
\hline
\end{tabular}

In addition to shorter recharge times than Level 1 connections, many Level 2 units also provide advanced transaction and management features. These features may include energy metering, transaction processing, access control, and managed charging to mitigate power demand. An overview of these features, as well as common applications, is displayed in Figure 3.

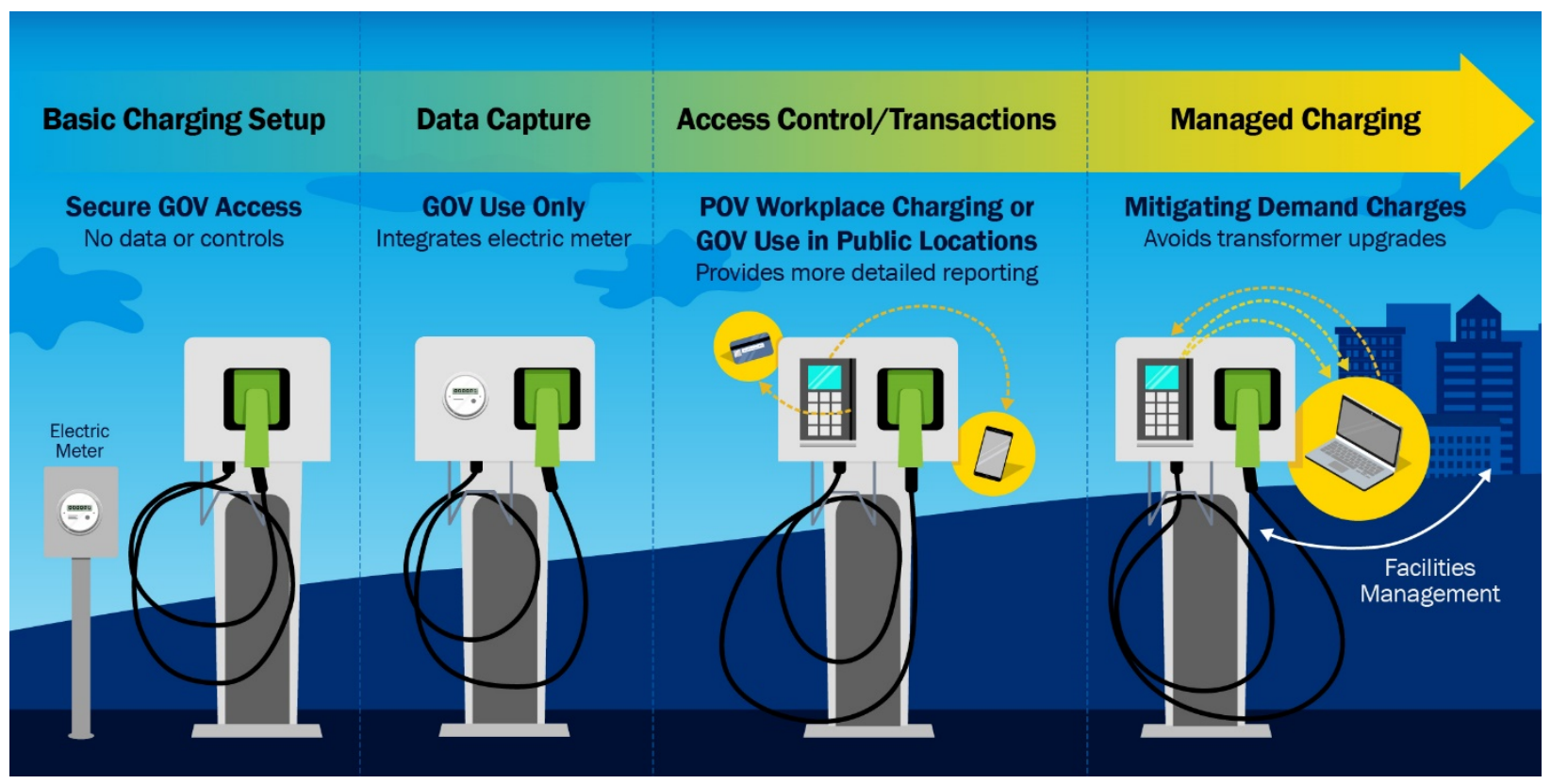

Figure 3. EVSE features and applications

Illustration by Joelynn Schroeder, NREL

A basic EVSE unit is designed to simply charge EVs by providing power to the vehicle and does not gather, store, or produce any additional data or include any access controls. These units are most useful in secure parking lots that only GOVs may access; however, measuring the energy provided to the vehicles with basic units requires a separate meter. Typically, one meter would be installed to track energy to a bank of EVSE units, and the garrison would need to estimate the electricity consumed by each vehicle. Reporting may be easier if the garrison installs a unit with built-in metering features. This allows the installation to track EV energy usage while avoiding the cost of installing metering infrastructure. 
In addition to metering, network connectivity is one of the most common advanced EVSE features that provides the ability to process transactions, control vehicle access, or manage charging. Transaction processing and access control are both useful for GOV-dedicated units in public locations, as well as units that permit POV use under a workplace charging program. Access may be granted using either a cell phone or credit card for POVs or a fleet card or ID pin for GOVs. Additionally, the most advanced units with managed charging are primarily designed to schedule charging needs to mitigate either high demand charges or reduce peak demand to avoid expensive transformer upgrades.

Many of the site visits in this first stage incorporate plans for relatively small numbers of EVs that will be stored in secure TMP locations. Therefore, managed charging would not necessarily be needed, and a lack of accessibility for POVs would make access control features unnecessary in many cases. This would make the basic dual-port Level 2 pedestal-style EVSE units the most economic choice for applications with secure GOV-only parking lots. However, while these basic units offer the lowest cost units per port, they lack the ability to meter energy use. In most installations these units would need to be served by a new electric service with a dedicated utility meter, or be fed through a submeter from an existing service panel. Despite basic units being less expensive, HQDA expressed interest in networked features to enable simpler reporting of consumed energy. Outside of fenced areas, access control might be necessary as well to prevent POVs from using GOV-dedicated units.

\subsection{Site Visits}

Site visits generally started with an on-site kickoff meeting where the interested parties introduced themselves and their roles. The group typically discussed the project background, reviewed preliminary information, identified priorities, and agreed upon a plan for the rest of the day. This plan often involved looking at an installation map to locate specific parking lots, reviewing the current and planned vehicle inventories and discussing the current and planned use of electric vehicles. Representatives included HQDA, USACE, NREL, the LRC (which manages most garrison fleet vehicles, including the TMP), and the DPW (generally responsible for facility improvements).

The Army wanted to deploy EVs first in the TMPs to socialize the technology through shortterm rentals. TMPs normally have a fence protecting the EVSE from unauthorized use, as well. The garrisons often preferred to install EVSE in fence-protected areas; however, the Tiger Teams informed visit participants that many networked EVSE units could function as a virtual fence, requiring access credentials via radio frequency identification (RFID), personal identification number (PIN), mobile phone application, or other authorization means.

After the TMP, the Tiger Team often visited other locations on base. They typically prioritized locations with high concentrations of GOV parking. In several cases, operational EVs were using Level 1 EVSE units if the garrison did not have Level 2 EVSE installed. The Level 1 units included $120 \mathrm{~V}$ wall outlet receptacles and portable $10 \mathrm{~A}$ or $12 \mathrm{~A}$ EVSE adapters that come standard with most EVs (Figure 4). 


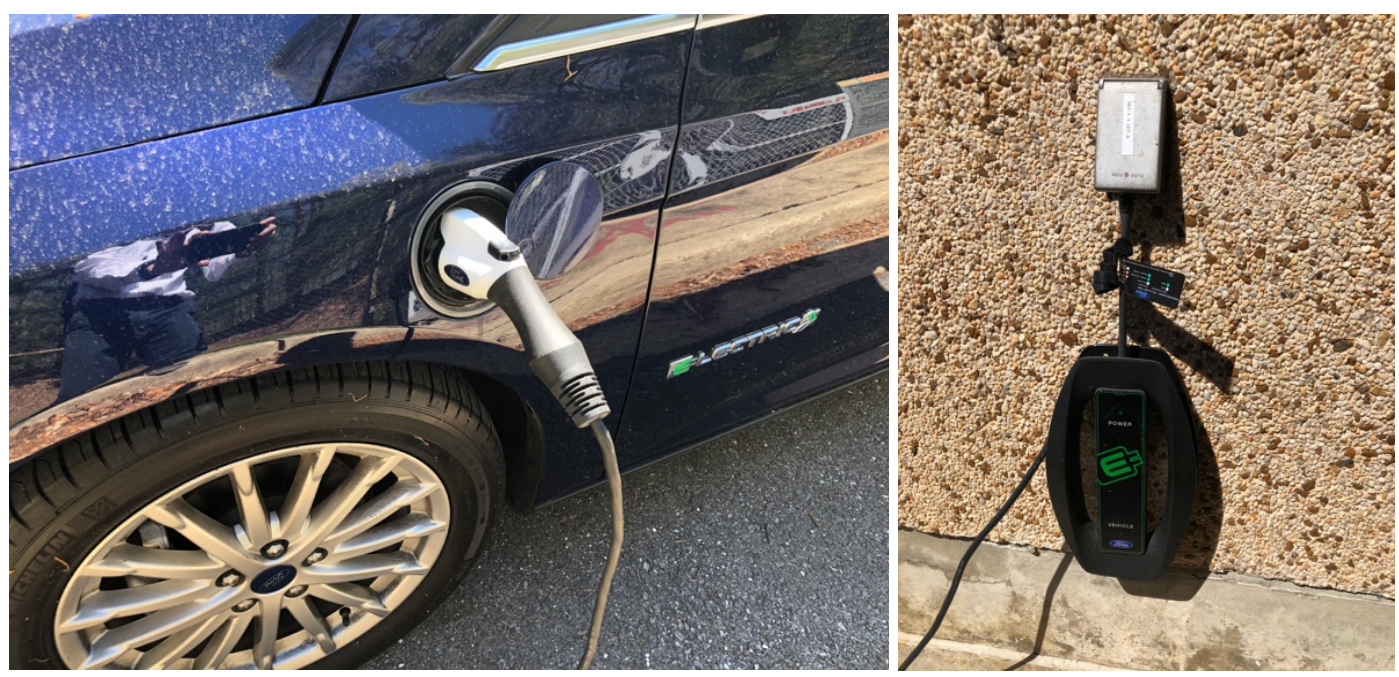

Figure 4. EV at Adelphi Laboratory Center connected to 120-V outlet

Photos by Kosol Kiatreungwattana, NREL

EVs can benefit from significantly faster Level 2 EVSE charging speeds as shown above in Table 4. For PHEVs, such as the Chrysler Pacifica, faster Level 2 charging over a one-hour lunch break can extend the daily EV range of the vehicle by more than $40 \%$. Alternatively, the longer-range batteries of all BEVs available on the GSA Schedule can be completely recharged overnight using Level 2 EVSE. HQDA directed the Tiger Teams to develop recommendations for Level 2 EVSE to charge the vehicles more quickly than Level 1 EVSE and at a much lower cost than DCFC.

Beginning in October 2018, the HQDA fleet manager began promoting employee workplace charging by expanding Tiger Team visits to POV-specific parking locations and condoning the use of POV charging at GOV-prioritized EVSE, if charging did not interfere with GOV access. Although federal agencies are permitted to provide POVs access to EVSE, they must do so at a no-cost basis for the federal government (Fixing America's Surface Transportation Act 42 USC $\S 6364)$. Because overseeing a reimbursement mechanism at an agency level can be challenging, HQDA was delegating the decision to allow workplace charging to the individual garrison; many garrisons chose not to allow such use. To facilitate POV use of EVSE, the Tiger Teams recommended garrisons purchase advanced EVSE with either access control or transaction processing features in those locations. These advanced units permit the facility to recoup the costs of providing energy to POVs, while also maintaining regular GOV access; however, POV charging was always a secondary mission next to the primary focus of developing EVSE for GOVs. 


\section{EVSE Assessment Results}

The site reports provided recommendations for the number of EVSE to support the specific needs of the garrison, locations of the EVSE, electric service considerations, and additional potential concerns. These recommendations did take into account the number of existing EVs the garrison owned at the time, as well as the planned growth of their EV fleet over the next three to five years.

\subsection{Standardizing Recommendations}

Although each site had many specific requirements, quite a few considerations were common across all garrisons.

The Tiger Teams had standardized a recommendation of Level 2 units that consume a peak current of 30 or $32 \mathrm{~A}$. This size was selected to accommodate a standard 40 A circuit breaker to protect each EVSE branch circuit. This breaker size is necessary for a unit consuming $32 \mathrm{~A}$ due to National Electric Code (NEC) Section 625, which requires all branch circuits with EVSE to have overcurrent protection sized for $125 \%$ of the maximum load. Additionally, Level 2 units require either $208 \mathrm{~V}$ or $240 \mathrm{~V}$, which corresponds to an available power of $6.7 \mathrm{~kW}$ or $7.7 \mathrm{~kW}$ at 32 A, respectively.

This standard EVSE size also resulted in consistent service panel upgrades. Each $208 \mathrm{~V}$ or $240 \mathrm{~V}$ branch circuit requires a double pole breaker to serve as the overcurrent protection. Each double pole breaker requires two vertically adjacent spare breaker positions in the building's service panel. These requirements, as well as those for Level 1 units are summarized in Table 5. This table outlines the number of breaker positions required, the voltage supplied, and the phase connections made for both Level 1 and Level 2 in buildings with single-phase three-wire or three-phase four-wire services. Lighting is advisable in many locations and would require an additional $120 \mathrm{~V}$ single-pole breaker or, alternatively, a neutral and a tap off of one of the EVSE phases.

Table 5. Service Panel Considerations for EVSE

\begin{tabular}{llclc}
\hline EVSE & Service & Positions & Voltage & Connections \\
\hline Level 1 & $\begin{array}{l}\text { 120/240, single-phase, } \\
\text { four-wire }\end{array}$ & $1(20 \mathrm{~A})$ & $\begin{array}{l}120 \mathrm{~V}, \text { single-phase, } \\
\text { line-neutral }\end{array}$ & L1-N or L2-N \\
Level 1 & $\begin{array}{l}\text { 208Y/120, three- } \\
\text { phase, four-wire }\end{array}$ & $1(20 \mathrm{~A})$ & $\begin{array}{l}120 \mathrm{~V}, \text { single-phase, } \\
\text { line-neutral }\end{array}$ & A-N, B-N, or C-N \\
Level 2 & $\begin{array}{l}\text { 120/240, single-phase, } \\
\text { four-wire }\end{array}$ & $2(40 \mathrm{~A})$ & $\begin{array}{l}240 \mathrm{~V}, \text { single-phase, } \\
\text { line-line }\end{array}$ & L1-L2 \\
Level 2 & $\begin{array}{l}\text { 208Y/120, three- } \\
\text { phase, four-wire }\end{array}$ & $2(40 \mathrm{~A})$ & $\begin{array}{l}208 \mathrm{~V}, \text { single-phase, } \\
\text { line-line }\end{array}$ & A-B, B-C, or C-A \\
\hline
\end{tabular}

In addition to Level 2 EVSE, the Tiger Teams also recommended dual-port pedestal-style units as an economical choice for most applications. Although wall-mount units are more affordable to procure and install, the Army TMPs generally did not have parking next to walls. Therefore, compared to single-port pedestal units, dual-port units offer garrisons a small incremental cost 
and more flexibility in outdoor environments, such as the parking lots of TMPs. This did necessitate an additional design consideration, as pedestal-style units must have wiring installed underground and will require trenching for conduit. Trenching can be one of the most expensive steps in the construction process for EVSE and is estimated at approximately $\$ 100-\$ 150$ per foot (DOE 2015). This led the Tiger Teams to suggest installing EVSE at locations close to distribution transformers or service panels. These construction considerations and price concerns strongly influenced the site selection process, which supported significant reductions in overall project costs.

Generally, the key factor determining EVSE location was proximity to electrical service. At Fort Jackson, for example, GOV parking was available on several sides of Building 2606. Assessing the location, the most accessible transformer was located on the east side, and a short trench through asphalt would reach a grassy area conducive to installing EVSE as shown in Figure 5.

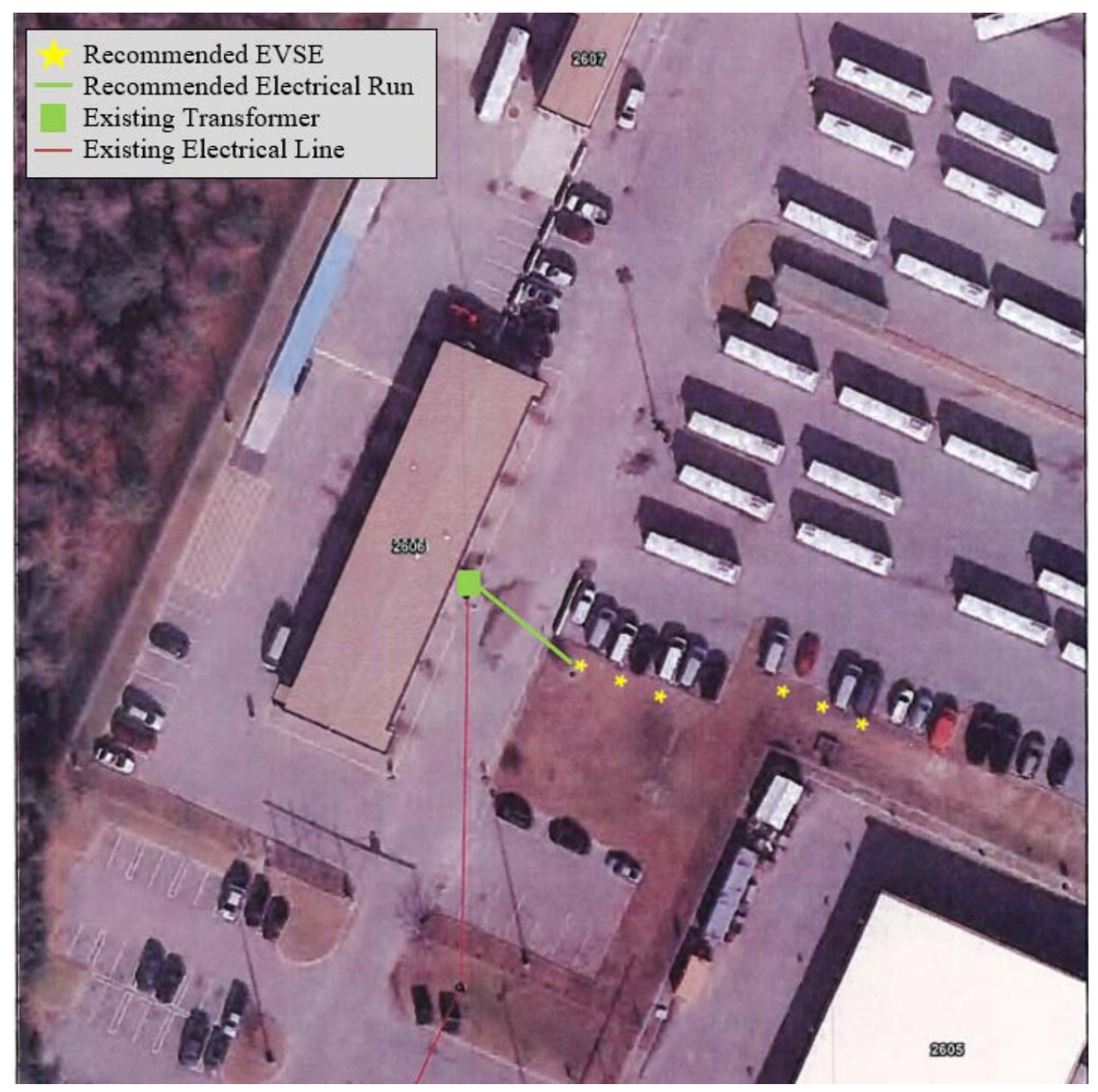

Figure 5. Recommended location of EVSE in Fort Jackson TMP based on transformer proximity

(c) 2019 Google Earth, alterations by Lauren Lynch, NREL 


\subsection{Summary of EVSE Assessments}

From these 30 site visits, the Tiger Teams recommended the installation of 252 EVSE to support the planned acquisition of 236 EVs. In some cases, more EVSE units were recommended than EVs to account for future growth, while in other cases, more EVs were planned than EVSE because they would be parked in locations that the Tiger Teams did not visit. This fleet growth would account for $17 \%$ of the participating fleet's sedans and station wagons, and $3 \%$ of their entire LD fleet. Most site recommendations included the suggestion for additional capacity to accommodate a growing EV fleet in the next three to five years. A summary of the plans and recommendations for each site is displayed in Table 6, while a map detailing the locations of each site is displayed in Figure 6.

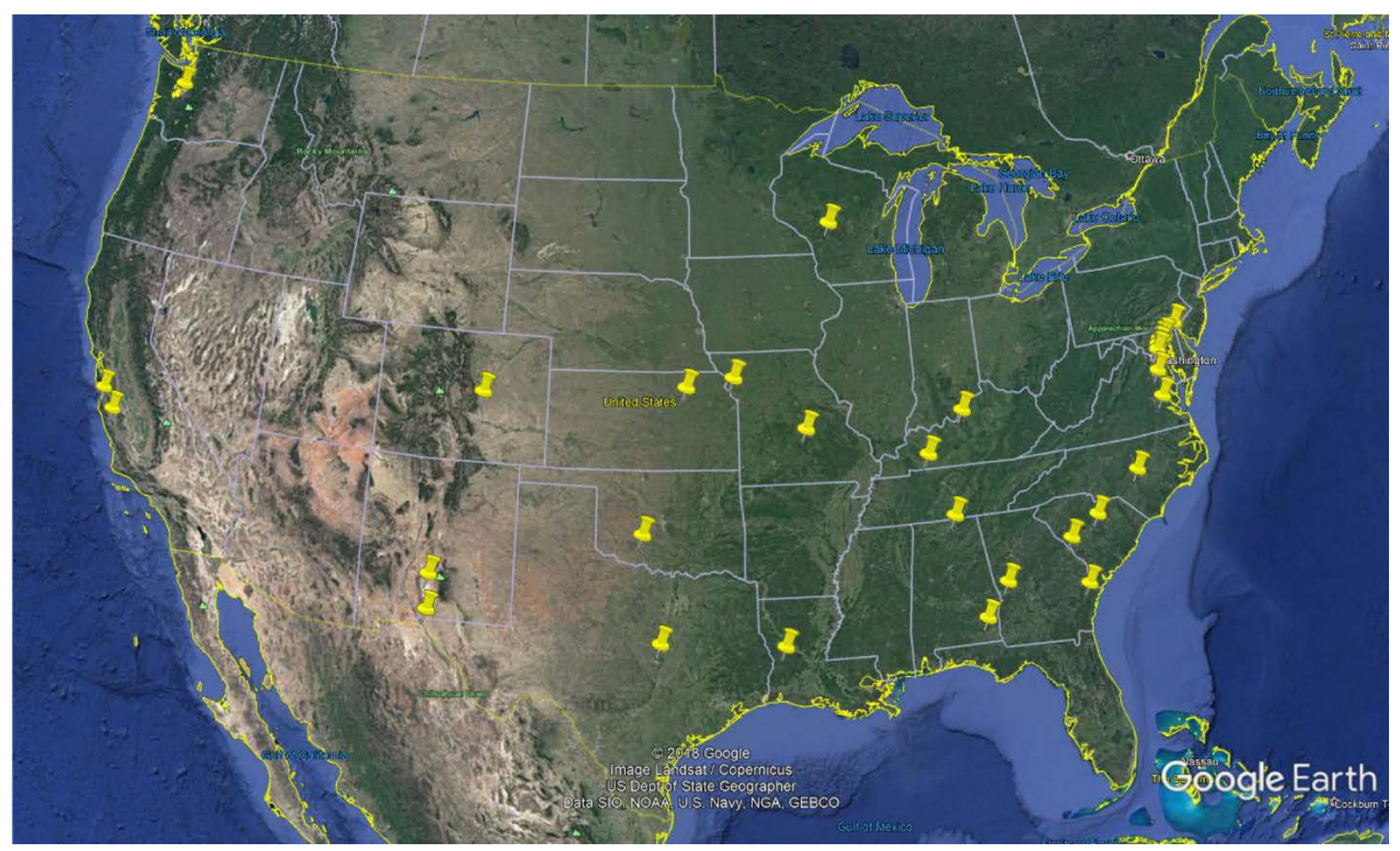

Figure 6. EV site assessment map

(c) 2019 Google Earth, alterations by James Salasovich, NREL

Table 6 includes a column summarizing the total EVs planned, which is a sum of the existing EVs and planned acquisitions by 2025. The planned acquisitions are the best estimate of future EV growth based on discussions between the garrison LRC and Tiger Team representatives. Additionally, the column summarizing the recommended Level 2 ports is a sum of the existing and recommended Level 2 EVSE ports. The final column summarizes the necessary electrical upgrades, although a more detailed summary of these recommendations may be found in Appendix B. 
Table 6. Garrison Planned EV Acquisitions and EVSE Recommendations

\begin{tabular}{|c|c|c|c|}
\hline Site & $\begin{array}{l}\text { Total EVs } \\
\text { Planned }\end{array}$ & $\begin{array}{l}\text { Recommended } \\
\text { Level } 2 \text { Ports }\end{array}$ & Electrical Upgrades Necessary \\
\hline Aberdeen & - & 4 & Install new service \\
\hline Adelphi & 5 & 6 & Install new service \\
\hline AP Hill & 4 & 6 & Install new service \\
\hline Belvoir & 6 & 14 & Install new subpanel \\
\hline Benning & 15 & 21 & Install new service \\
\hline Bliss & 8 & 6 & Upgrade service panel, CNG recommendation \\
\hline Bragg & 5 & 10 & Install new service \\
\hline Buchanan & 9 & 10 & Upgrade service, upgrade to dual-port L2 \\
\hline Campbell & 0 & 0 & CNG recommendation \\
\hline Carson & 6 & 6 & Install new service \\
\hline Gordon & 10 & 14 & Install new service, install new sub-panel \\
\hline Hood & 5 & 8 & Install new transformer, upgrade L1 EVSE to L2 \\
\hline Hunter Liggett & 2 & 12 & Install new subpanel \\
\hline Jackson & 11 & 12 & Install new subpanel, CNG recommendation \\
\hline Knox & 20 & 16 & Install new subpanel, CNG recommendation \\
\hline Leavenworth & 8 & 6 & Upgrade service panel to $400-\mathrm{A}$ \\
\hline Lee & - & 10 & General EVSE recommendations \\
\hline Leonard Wood & 10 & 8 & Install new service \\
\hline Lewis McChord & 8 & 6 & Install new service \\
\hline Meade & - & 2 & General EVSE recommendations \\
\hline McCoy & 53 & 10 & Install new service \\
\hline Monterey & 10 & 10 & Install new subpanel \\
\hline Myer-Henderson & 5 & 7 & Install new subpanel \\
\hline Polk & 5 & 6 & Install new service, upgrade subpanel, CNG \\
\hline Redstone & 11 & 10 & Install new service \\
\hline Riley & 10 & 10 & Install new service \\
\hline Rucker & 6 & 6 & Install new subpanel \\
\hline Sill & 0 & 6 & Install new subpanel, CNG recommendation \\
\hline Stewart & 2 & 8 & Install new subpanel \\
\hline White Sands & 2 & 2 & Install new service, Install new subpanel \\
\hline
\end{tabular}




\subsection{Number of EVSE}

The number of EVSE was typically dictated by anticipated demand, although it was dependent on parking availability and electrical capacity as well. In many cases, the Tiger Teams presented multiple options that depended on existing loads on service panels or transformers. Many recommendations also included options for future growth in locations where either the infrastructure could serve additional units or the garrison had plans for additional EVs.

In the case of Fort McCoy, which had the most aggressive plans for expanding their EV fleet, the Tiger Team recommended installing service equipment with additional capacity through "make-ready" stubs. A general layout of this design is displayed in Figure 7, in which the green indicates new electric service equipment, blue represents the proposed EVSE, and red signifies the location of stubs. A stub is essentially a place holder of electrical conduit and allows for easy EVSE installations at the location when desired. These stubs, an example of which is displayed in Figure 8, provide the flexibility for installing additional EVSE because the underground conduit for additional units is installed during initial construction instead of conducting another round of construction. 


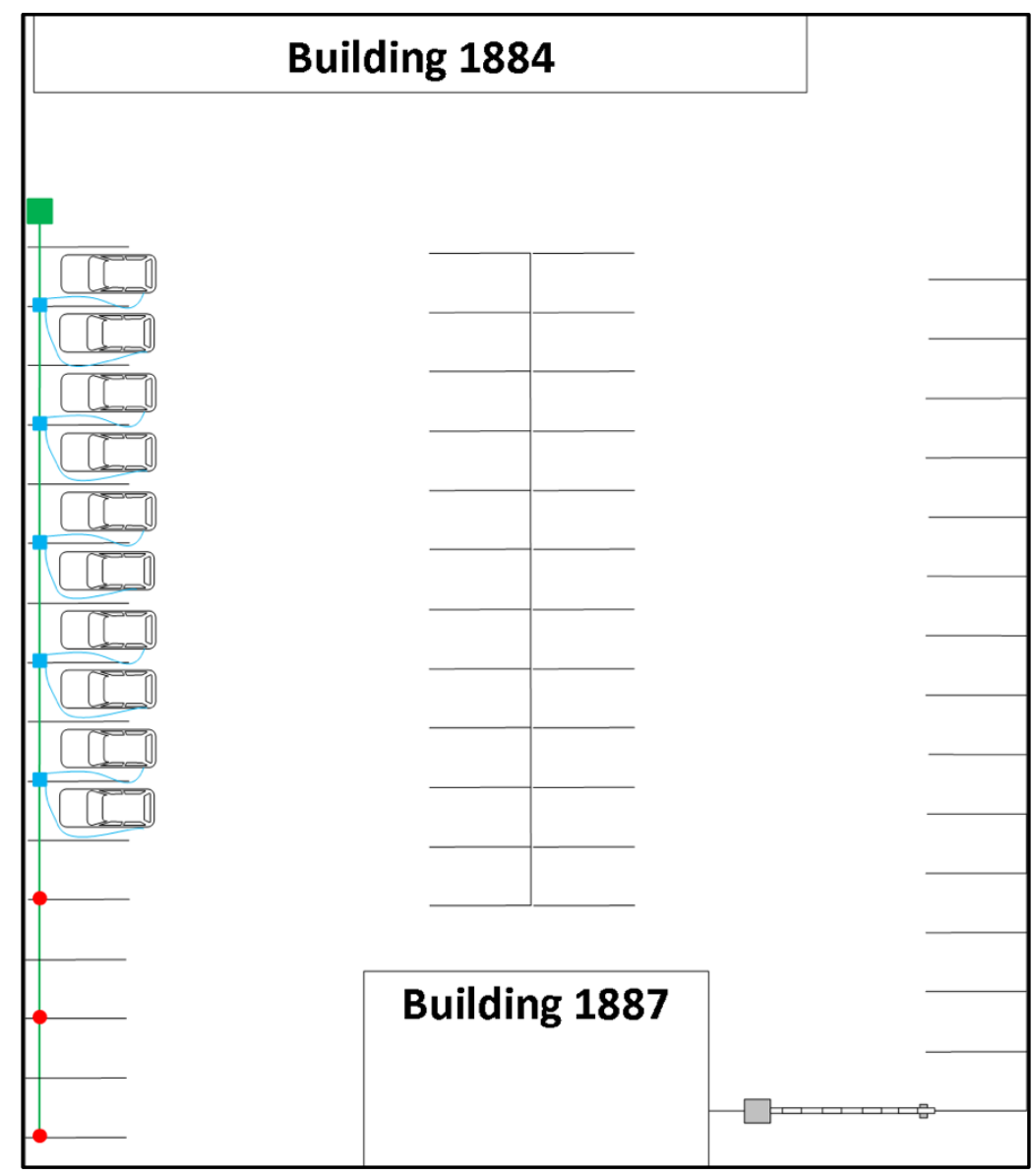

Figure 7. Fort McCoy TMP general layout with expansion

Illustration by Jesse Bennett, NREL

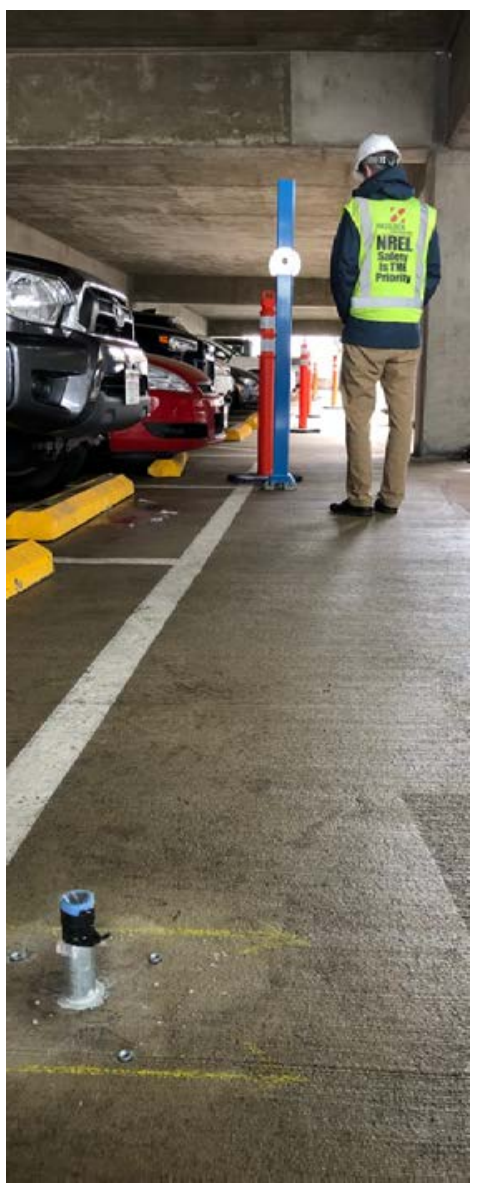

Figure 8. EVSE stub

Photo by Jesse Bennett, NREL

The new electric service, dedicated solely for EVSE, will initially serve 10 Level 2 ports, but will have the capacity to supply power to as many as 15 . Fort McCoy has indicated aggressive plans for their EV fleet. Over the next five years, the LRC anticipates it will acquire as many as 50 EVs. The 10 units that will be installed in the TMP at Buildings 1884 and 1887 will serve the EVs acquired in the initial phase; however, if the LRC's EV program progresses faster than expected, the garrison will be able to expand from 10 to 15 ports quickly and with minimal construction costs. Although the Tiger Team in this case recommended going forward with construction plans accounting for expansion, both options presented are listed in Table 7. 
Table 7. EVSE Infrastructure Options for the TMP at Fort McCoy Buildings 1884 and 1887

\begin{tabular}{|c|c|c|c|}
\hline Option & Description & Advantages & Drawbacks \\
\hline Option A & $\begin{array}{l}\text { Install a new service and five } \\
\text { Level } 2 \text { dual-port pedestal units } \\
\text { along the exterior of the TMP } \\
\text { parking surface. }\end{array}$ & $\begin{array}{l}\text { Lower initial construction } \\
\text { cost. }\end{array}$ & $\begin{array}{l}\text { High cost to } \\
\text { expand capacity to } \\
\text { accommodate } \\
\text { future EV growth. }\end{array}$ \\
\hline $\begin{array}{l}\text { Option B } \\
\text { (Preferred) }\end{array}$ & $\begin{array}{l}\text { Install a new service and five } \\
\text { Level } 2 \text { dual-port pedestal units, } \\
\text { as well as three make-ready } \\
\text { stubs, along the exterior of the } \\
\text { TMP parking surface. }\end{array}$ & $\begin{array}{l}\text { Designed to accommodate } \\
\text { additional EVSE units. } \\
\text { Lower overall cost to install } \\
15 \text { ports in total. }\end{array}$ & $\begin{array}{l}\text { Higher initial } \\
\text { construction cost. }\end{array}$ \\
\hline
\end{tabular}

This planning approach for EVSE expansion requires a nominal increase in trenching and conduit costs during the initial phase of construction; however, this approach reduces the overall cost by mitigating later upgrades that would have been more expensive. Instead of building for expansion at one location, other sites preferred installing EVSE at two separate locations. This gave the existing EV fleet the flexibility to charge in different parking lots, while also maintaining the capacity to serve additional vehicles in the future.

One location, Fort Carson, had multiple TMP locations that could house EVSE. To prepare the installation for additional growth, the Tiger Team recommended installing six EVSE ports each at two different locations. This would offer Fort Carson's EV drivers the flexibility to charge at multiple locations and provide additional charging capacity for the future. Each of these locations required upgrades that could also be designed to accommodate additional EVSE for even further expansion. Figure 9 and Figure 10 represent each of the locations and display the transformer, service panel, and additional parking locations. 


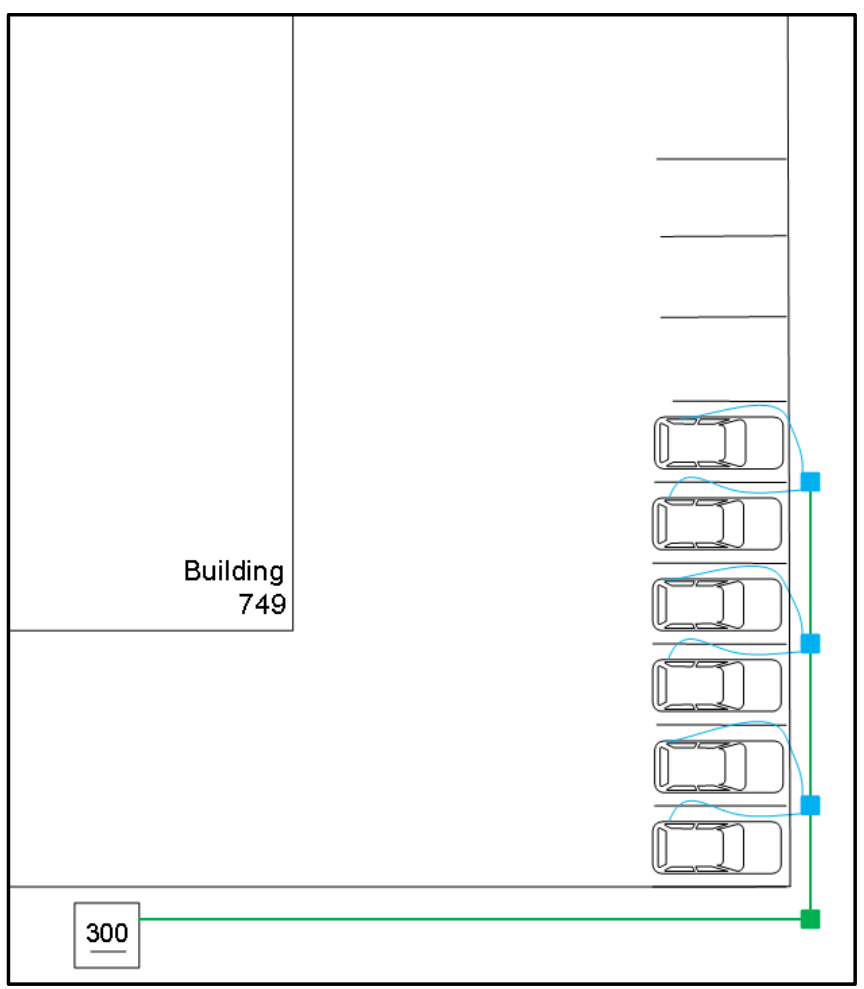

Figure 9. Fort Carson Building 749 layout

Illustration by Jesse Bennett, NREL

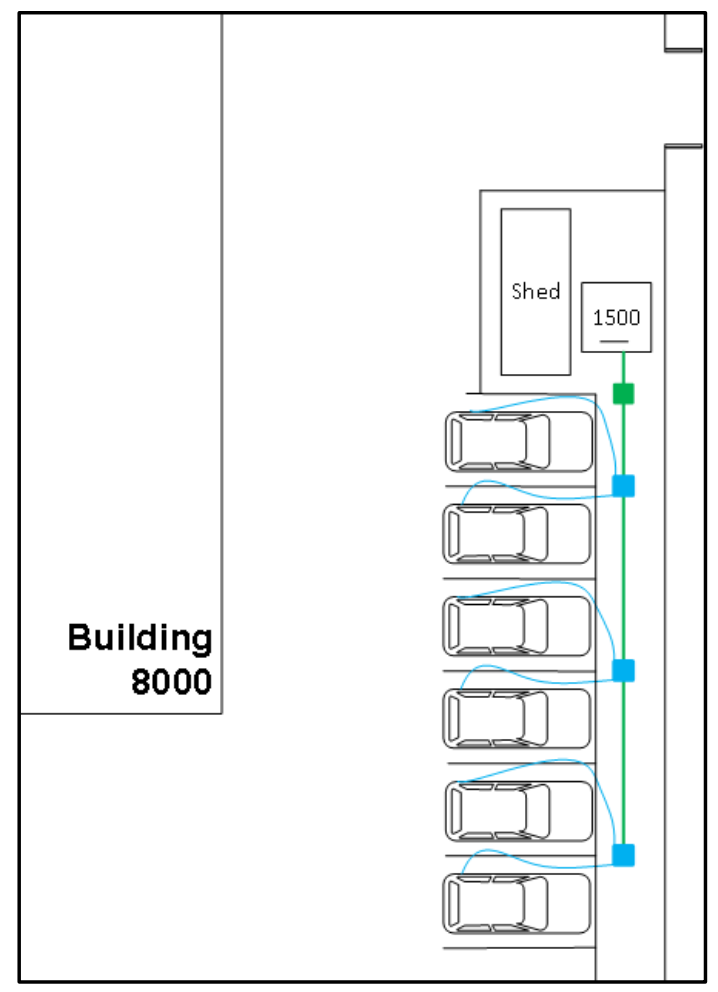

Figure 10. Fort Carson Building 8000 layout

Illustration by Jesse Bennett, NREL

Fort Carson stated a preference for providing the flexibility for their vehicles to charge at multiple locations. The garrison also shared the intention to continue growth of its EV fleet, which will require EVSE expansion. However, Fort Carson and the Tiger Team discussed how the expense of equipment upgrades and trenching might limit installing units at both locations. Therefore, the Tiger Team indicated in Table 8 that Building 8000 should be prioritized due to its larger transformer capacity $(1,500 \mathrm{~kW}$ transformer, as indicated in Figure 10), as well as the minimal trenching required.

Table 8. EVSE Infrastructure Options for the TMP at Fort Carson Buildings $\mathbf{7 4 9}$ and 8000

\begin{tabular}{llll}
\hline Option & Description & Advantages & Drawbacks \\
\hline Option A & $\begin{array}{l}\text { Install a new service and three } \\
\text { Level 2 dual-port pedestal units } \\
\text { along the exterior of the parking } \\
\text { surface at Building 749. }\end{array}$ & $\begin{array}{l}\text { Preferred parking } \\
\text { location for future EVs }\end{array}$ & $\begin{array}{l}\text { Significant trenching } \\
\text { distance required }\end{array}$ \\
$\begin{array}{l}\text { Option B } \\
\text { (Preferred) }\end{array}$ & $\begin{array}{l}\text { Install a new service and three } \\
\text { Level 2 dual-port pedestal units } \\
\text { along the exterior of the parking } \\
\text { surface at Building 8000. }\end{array}$ & $\begin{array}{l}\text { Relatively short trenching } \\
\text { distance required }\end{array}$ & $\begin{array}{l}\text { Secondary parking } \\
\text { location for future EVs }\end{array}$ \\
\hline
\end{tabular}




\subsection{Parking Optimization}

In most cases, parking was available in the general area where garrisons were interested in EVSE; however, in some cases, the spots were reserved for specific uses, such as handicapped users or specific employees. Some of these spots could not be repurposed. For example, at Fort MyerHenderson Hall, the handicapped parking was located very close to service panels with excess capacity in the mechanical room, but they were the only spots available near a wheelchair ramp. Wheelchair access was the top priority in that case, and the Tiger Team looked at other installation locations instead of those spots. In another example at Aberdeen Proving Ground (Figure 11), the parking was reserved for high-ranking officials as a

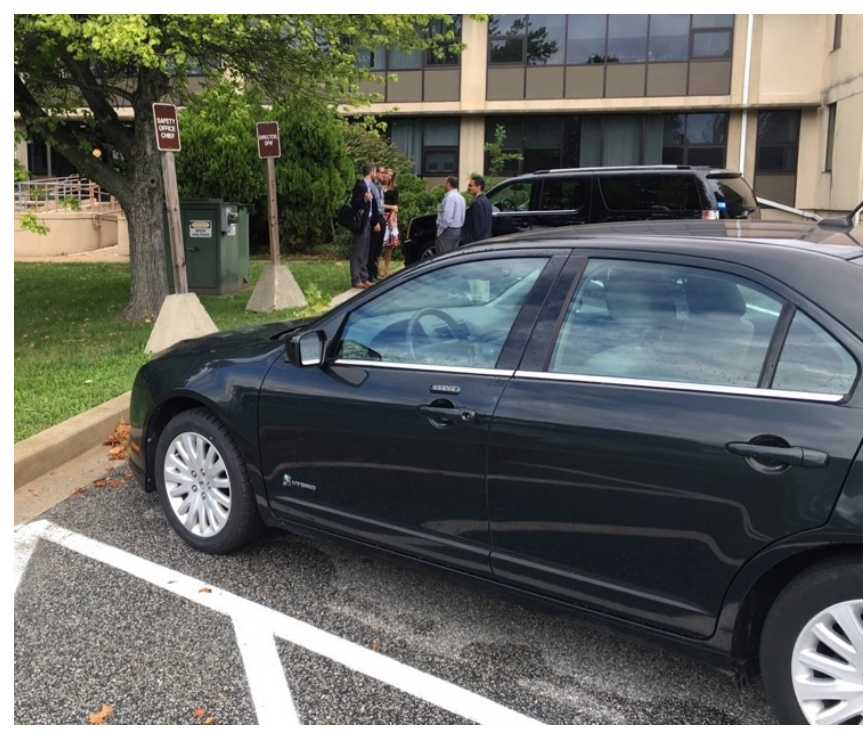

Figure 11. Reserved parking spaces for special use Photo by Chuck Kurnik, NREL perk, and the garrison DPW felt comfortable reassigning those spots because the nearby access to a transformer would eliminate trenching and allow for a simple installation of EVSE.

In some cases, EVSE may be configured as double-sided to minimize trenching and optimize parking space, as shown in Figure 12.

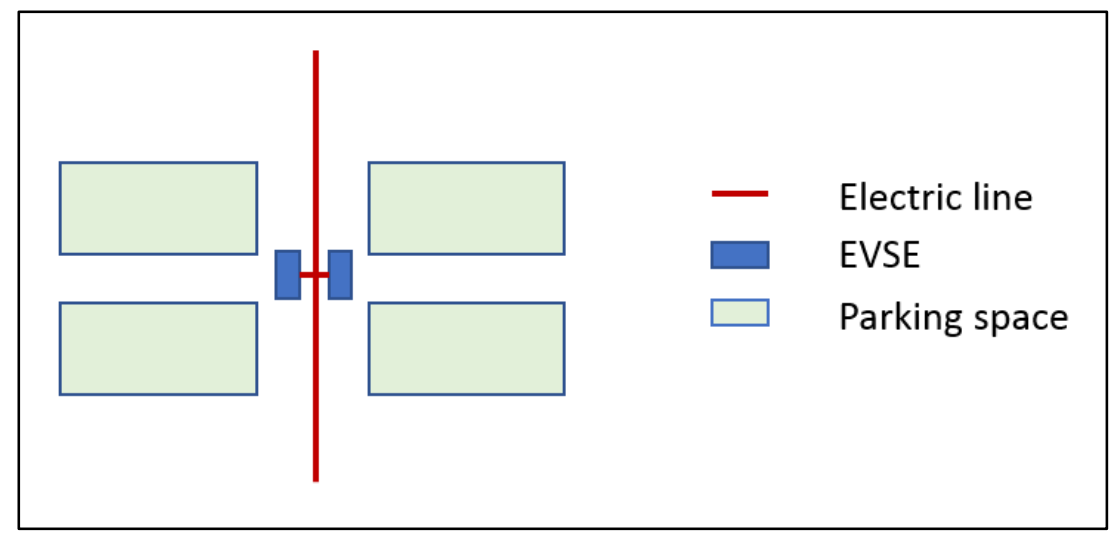

Figure 12. Double-sided parking diagram

Illustration by Kosol Kiatreungwattana, NREL

The TMP at Fort Leonard Wood illustrates a good example of this application, in Figure 13. In both options, the EVSE must be installed in the middle of the lot to accommodate other parking needs. To minimize the footprint of the EVSE, trenching, and protection required, two dual-port pedestal units can be installed back to back. 


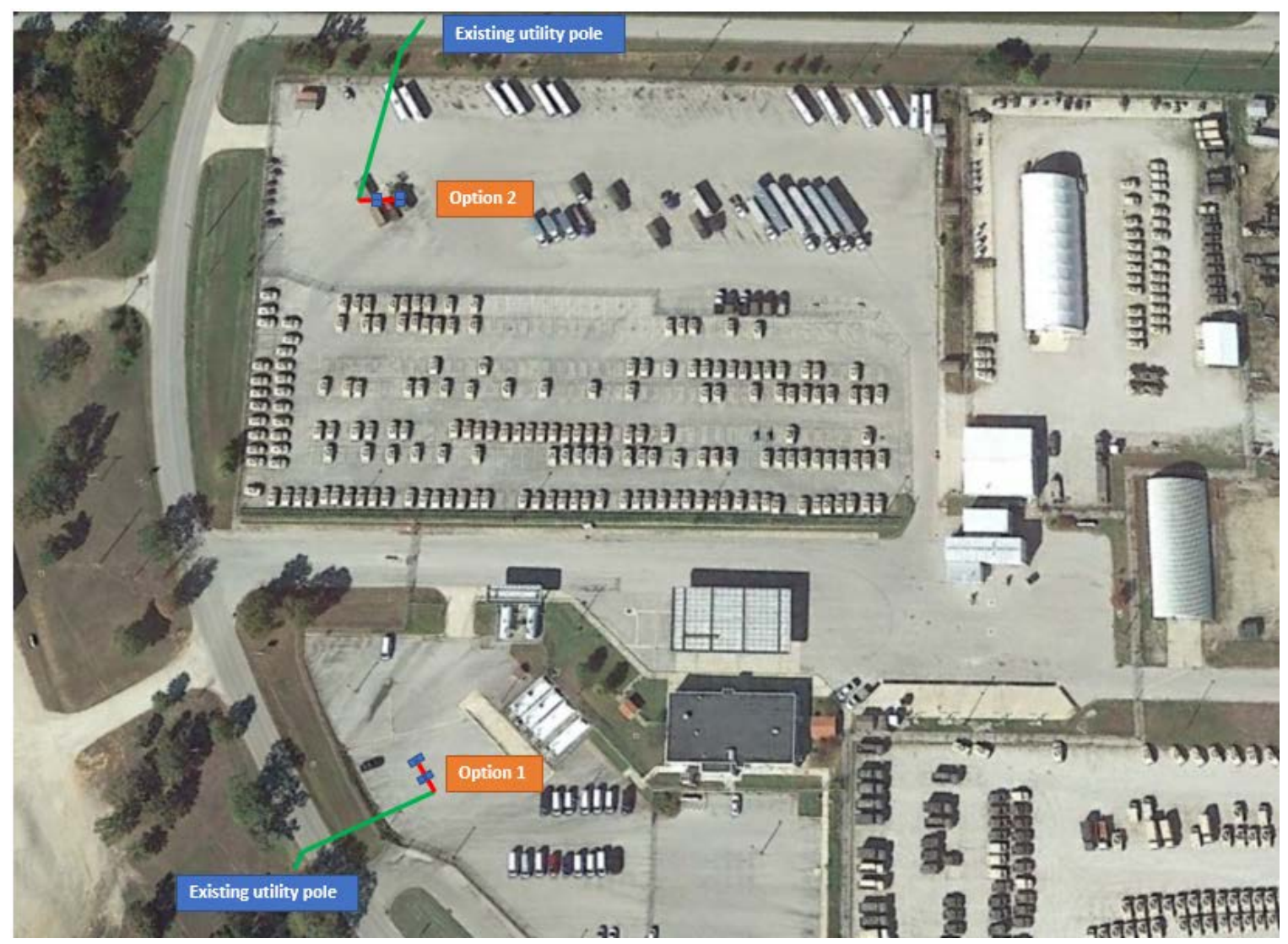

Figure 13. Options for EVSE installation at Fort Leonard Wood

(c) 2019 Google Earth, alterations by Kosol Kiatreungwattana, NREL

\subsection{Electrical Service}

After selecting the type and quantity of EVSE to be installed, the Tiger Teams determined the best source of electricity to power these units. The teams assessed all electric service equipment from the distribution service transformer and service drop wires down to the utility demand meter and the electric service panel for each building and site under consideration. In many situations this process required close collaboration with the local utility. The utility company was able to determine a transformer's spare capacity and decide if a larger unit would be needed to serve this new load. They were also crucial in discussions around the options to upgrade an existing electric service or consider a new service interconnection that would be dedicated to the EVSE.

Both the distribution service transformer and the service drop wires must have sufficient spare capacity to accommodate the new EVSE load. Under the Army's Utilities Privatization Program, this equipment is commonly the responsibility of the utility, who will cover the cost of necessary upgrades; however, many garrisons have not privatized their electric service and own and maintain this equipment themselves. In those circumstances, any upgrades to this equipment are the full responsibility of the garrison.

It was often the case that the Tiger Teams could not ascertain the rating or voltage of the overhead transformers or conductors during the visit. DPW staff did not always have records of 
their size or loading. For example, at Fort A.P. Hill, the Tiger Team observed three overhead single-phase transformers with one length of triplex conductor from the utility pole to the light pole, which then continued to the nearby building (Figure 14).

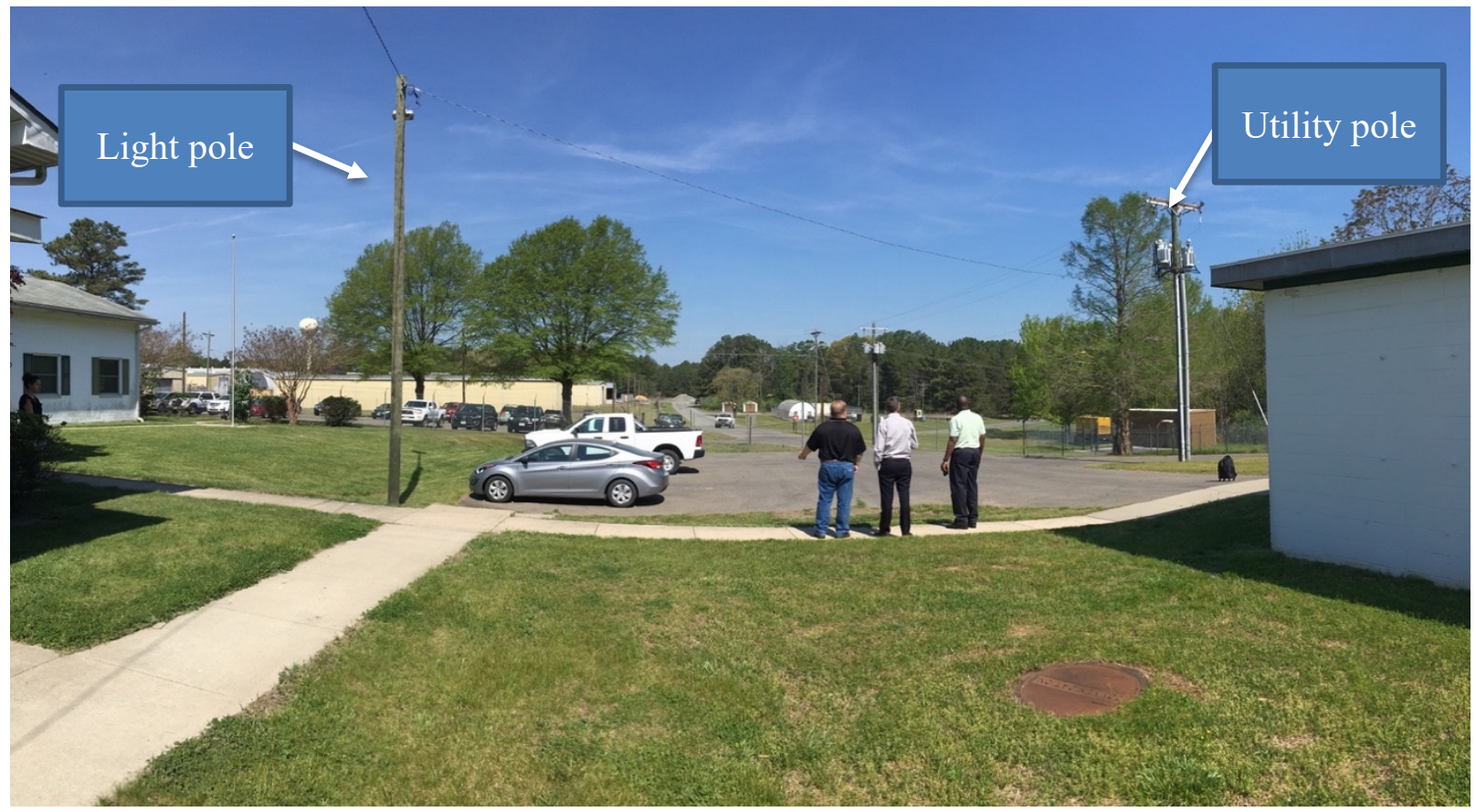

Figure 14. Overhead transformer connection at Fort AP Hill

Photo by Chuck Kurnik, NREL

The Tiger Team was unable to determine if the conductor in question might carry sufficient power with excess capacity for the new EVSE desired by Fort A.P. Hill. The team recommended that Fort A.P. Hill work with their local utility to make the determination.

In other cases, overhead transformers were clearly marked, and they could be traced directly to service panels. For example, at Fort Bliss the transformer shown in Figure 15 is marked 50 (likely the apparent power rating of 50 kilovolt-amperes [kVA]) and is connected to a single phase of primary voltage. The three conductors leaving the transformer are likely the two $120 \mathrm{~V}$ legs, and a neutral, which can be confirmed by the three-wire 120/240 V panel to which it is connected (Figure 16). 

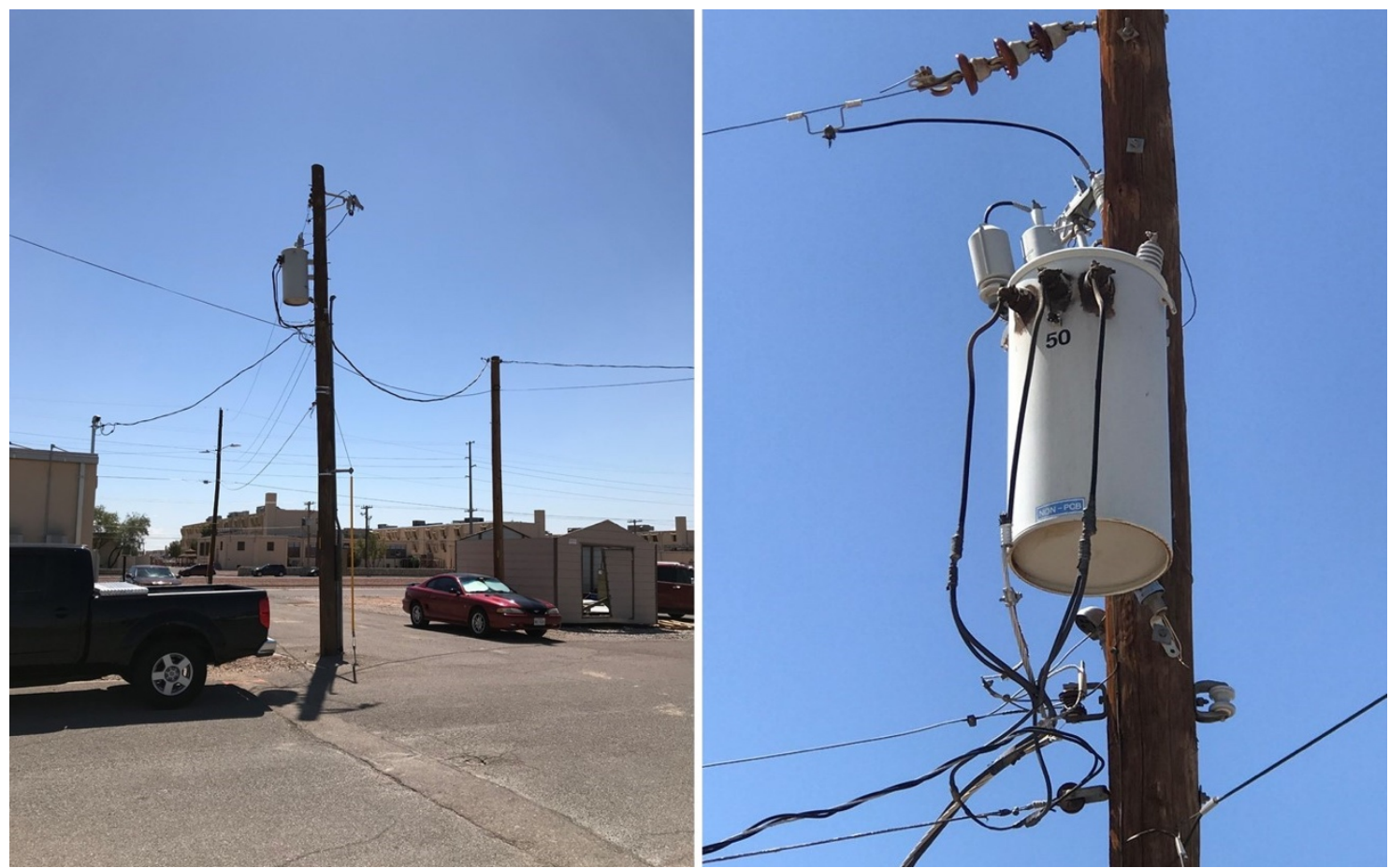

Figure 15. Single-phase 50 kVA transformer at Fort Bliss

Photos by Jimmy Salasovich, NREL

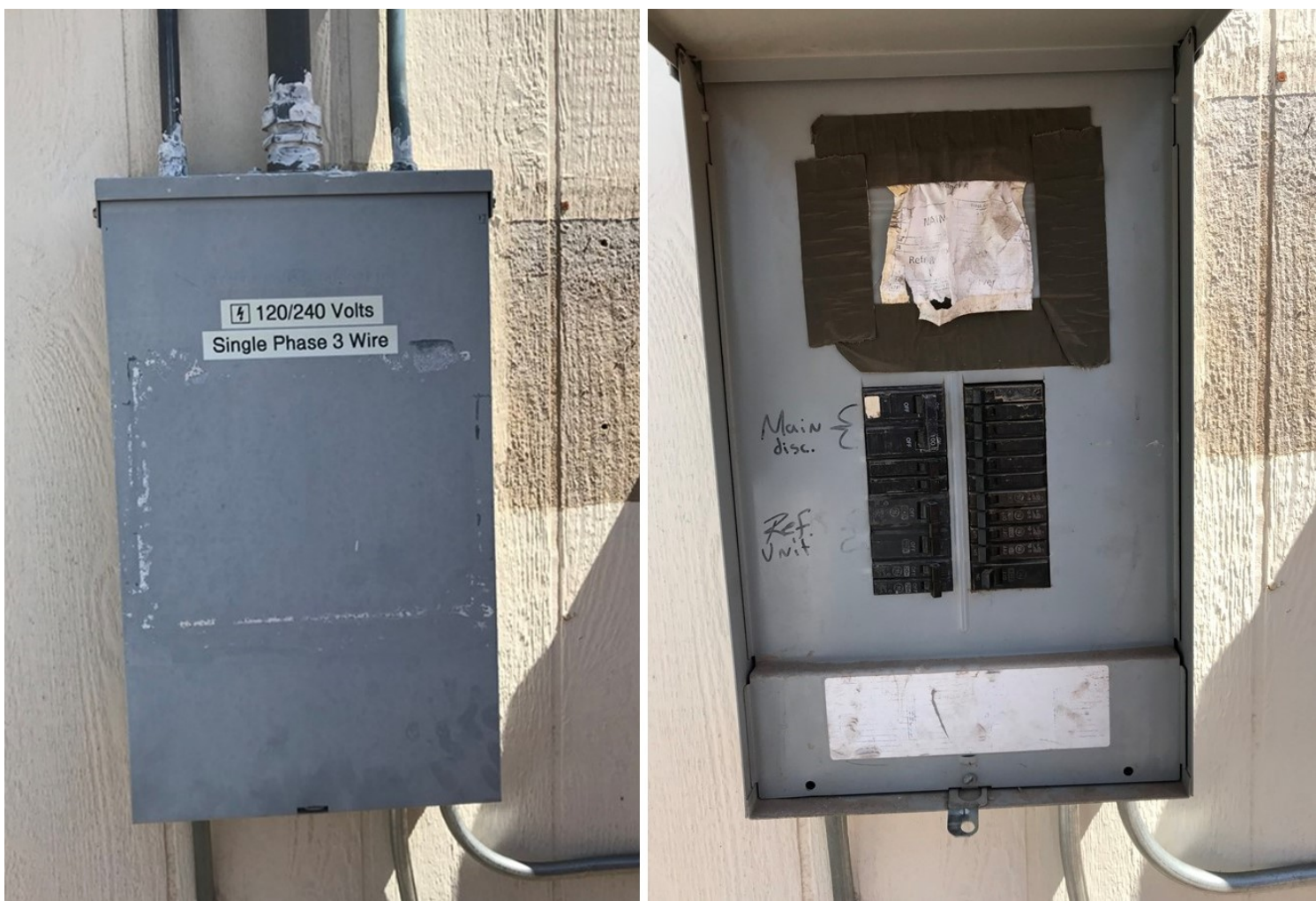

Figure 16. Single-phase service panel at Fort Bliss

Photo by Jimmy Salasovich, NREL 
Installing demand meters would be the ideal way to determine the electrical load for a given transformer. Unfortunately, it was rare that garrisons had demand meters installed, although Fort Belvoir did, as shown in Figure 17. This meter alternated between screens showing energy consumption over the current billing period and the maximum load to date for that period. This, coupled with historical records from the utility, allowed for a more accurate assessment of available power than could typically be determined.

Alternatively, the Tiger Teams could review electrical diagrams to approximate building loads, or they could estimate loads more generically, although each of these methods could generate erroneous values and required conservative approaches.

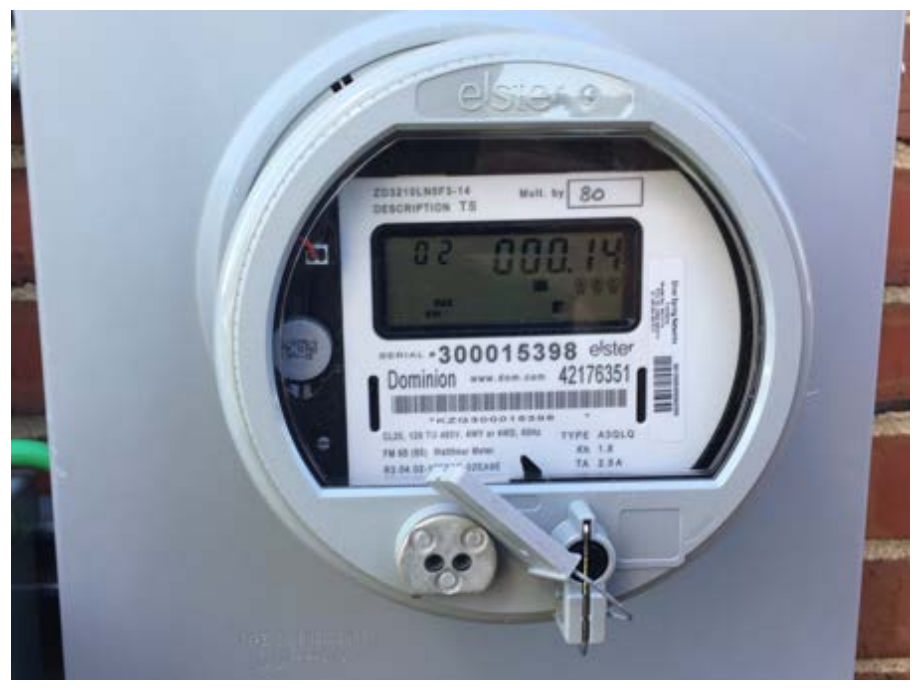

Figure 17. Fort Belvoir power demand meter

Photo by Cabell Hodge, NREL

Additionally, the Tiger Teams investigated the ability of the service panel to accommodate the branch circuits necessary for additional EVSE. This either resulted in recommending upgrades to existing service panels, considering main breaker sizing and spare breaker positions, or installing a new service.

Many of the locations that garrisons selected for EVSE had existing electric services and equipment that could accommodate the additional load. At Joint Base Fort Myer-Henderson

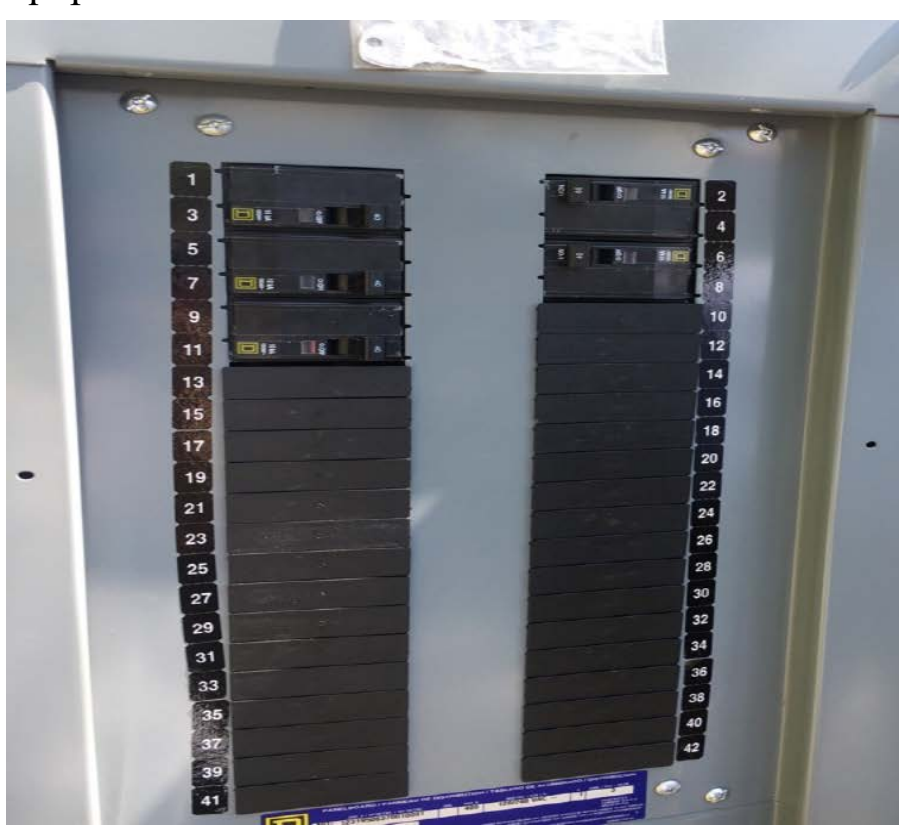

Figure 18. Service panel at Fort Myer-Henderson TMP Hall, five single-port EVSE units had been installed in the TMP lot, along with a dedicated electrical service panel with a main breaker rated at $400 \mathrm{~A}$ (Figure 18). Because each port only requires a $40 \mathrm{~A}$ circuit breaker, the panel can easily support the additional five EVSE units that would suffice to serve the joint base's needs.

In the case of Fort Leavenworth, Building 687 was serviced by two separate electric services. As displayed in Figure 19, one service has a 225 A main breaker and serves the car wash, while the other service is protected through a 150 A breaker and serves the building's lighting load.

Photo by Lauren Lynch, NREL 


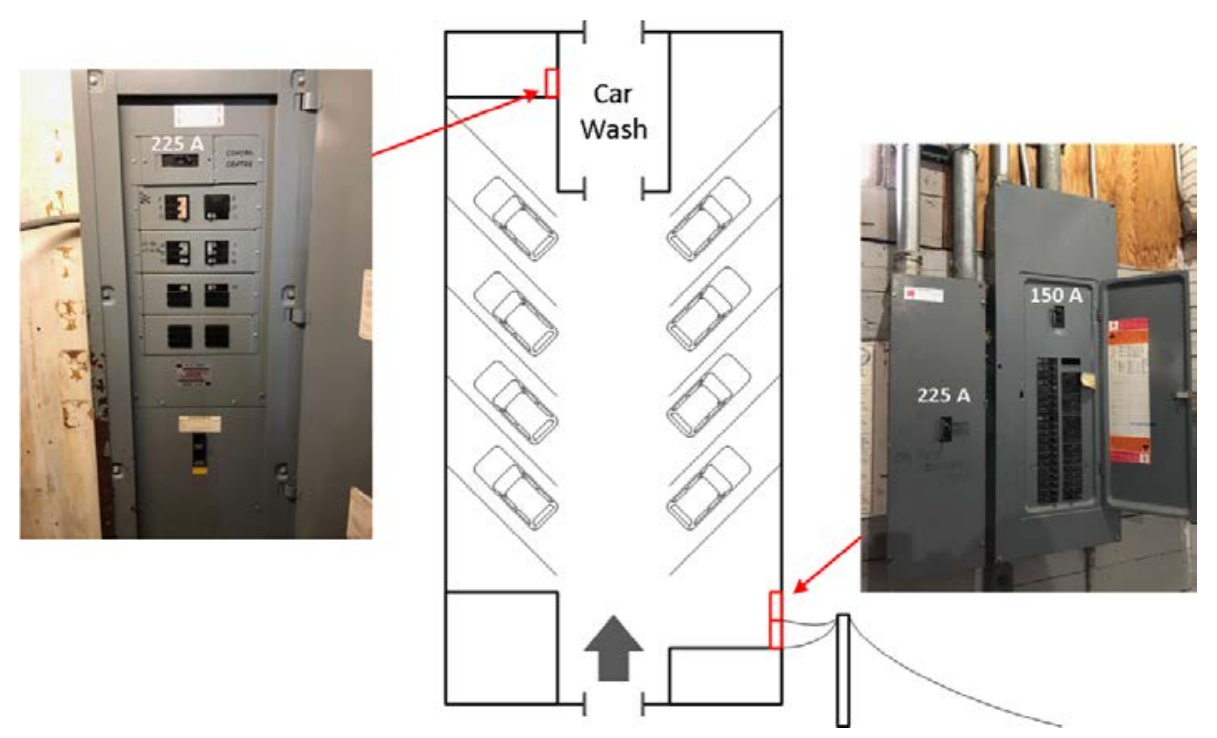

Figure 19. Electric service layout of Fort Leavenworth's TMP at Building 687

Photos and illustration by Jesse Bennett, NREL

Based on the existing equipment, the Tiger Team determined a simple upgrade to the lighting service, from a 150 A main breaker to a 400 A main breaker, would provide the necessary capacity to power the lighting load and six new Level 2 EVSE ports. These recommendations, as well as an alternate equipment option, are displayed in the Table 9 summary.

Table 9. EVSE Infrastructure Options for the TMP at Fort Leavenworth Building 687

\begin{tabular}{llll}
\hline Option & Description & Advantages & Drawbacks \\
\hline $\begin{array}{l}\text { Option A } \\
\text { (preferred) }\end{array}$ & $\begin{array}{l}\text { Install three Level 2 dual- } \\
\text { port wall-mount units } \\
\text { inside Building 687. }\end{array}$ & $\begin{array}{l}\text { Most affordable } \\
\text { and convenient } \\
\text { location for install }\end{array}$ & $\begin{array}{l}\text { Requires the purchase of new EVSE } \\
\text { units. }\end{array}$ \\
\hline & $\begin{array}{l}\text { Install three existing } \\
\text { EVSE ground-mounted } \\
\text { Option B } \\
\text { padestals on concrete } \\
\text { padside Building 687. }\end{array}$ & $\begin{array}{l}\text { Lower equipment } \\
\text { costs }\end{array}$ & $\begin{array}{l}\text { High installation costs to trench } \\
\text { raceway to concrete pad } \\
\text { Concerns related to GE warranty. }\end{array}$ \\
\hline
\end{tabular}

Some installations did not have sufficient capacity on their existing services and required a new electric service to accommodate new EVSE. Generally, for EVSE connected to new electrical services, the Tiger Teams recommended a new meter and panel with a disconnect, such as the mounting configuration shown in Figure 20 and illustrated in a recommendation for Fort Riley in Figure 21. The new panel should be sized to serve the new EVSE load and the meter would be used by the facility management team to isolate the EVSE load from their energy management reporting; however, if the EVSE units are networked and the facility manager is granted access to the network application (typically via desktop browser or mobile applications), this meter is unnecessary.

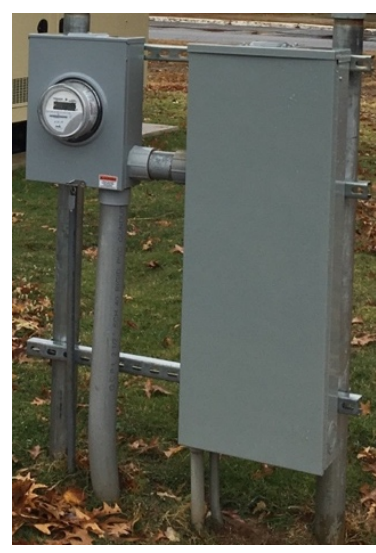

Figure 20. Meter and panel

Photo by Chuck Kurnik, NREL 


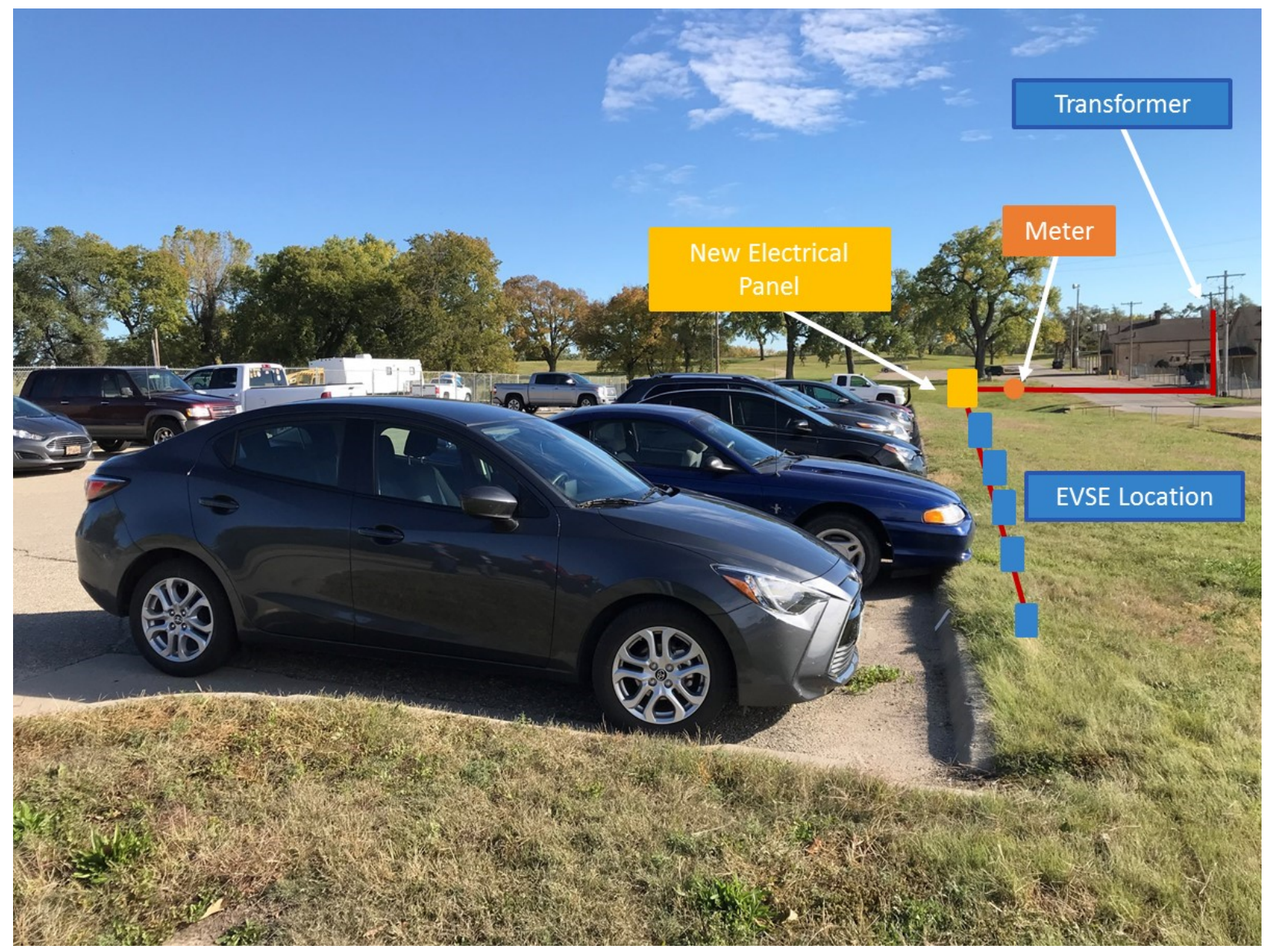

Figure 21. Recommended EVSE installation at Fort Riley

Photo by Jimmy Salasovich, NREL

\subsection{Peak Demand Concerns}

As previously noted, one key concern about EVSE installation is the potential equipment upgrades that may be needed to serve the additional load. The most expensive example of this is often when the distribution service transformer is unable to supply the peak EVSE demand. Often the local utility will cover the cost of equipment upgrades, such as a transformer or service drop; however, in cases where the garrison owned the distribution transformers, the garrison would be responsible for the additional cost. In these circumstances, the full cost of a new transformer would significantly increase the total cost of construction. This concern is most common when either a new electrical service is installed, or the electric service panel is upgraded with a larger main circuit breaker.

In addition to equipment upgrades, the higher peak demand from new EVSE also has the potential to significantly impact the cost of electricity. Many utilities have a rate structure in which a demand charge is added on top of the cost of electricity consumed. This demand charge is defined by the peak demand, measured in $\mathrm{kW}$, of power consumed during each billing cycle. If a facility's peak load coincides with the EVSE load, the demand charge portion of the garrison's 
electricity bill could greatly increase. This becomes a growing concern as the number of EVSE increases and should always be discussed with the local utility company, due to variance in rate structures between each electric utility.

\subsection{Managed Charging}

A common approach used to mitigate the costs associated with peak demand is employing a managed charging system. In some cases, the Tiger Teams offered the option of managed charging, which would allow for a greater total nameplate capacity of EVSE than the electrical infrastructure typically could serve. It also, when coupled with a facility management system, can lower the cost of demand charges by reducing coincidence peaks between the EVSE and facility loads.

For example, Fort Belvoir expressed interest in significantly increasing the number of EVSE in their parking lot at a future date; however, they were limited by the $150 \mathrm{kVA}$ transformer servicing Building 187. Fort Belvoir was able to acquire historical demand data for this site. Figure 22 displays the monthly peak demand from January 2016-May 2018, in which the highest peak of $67 \mathrm{~kW}$ occurred in August of 2016.

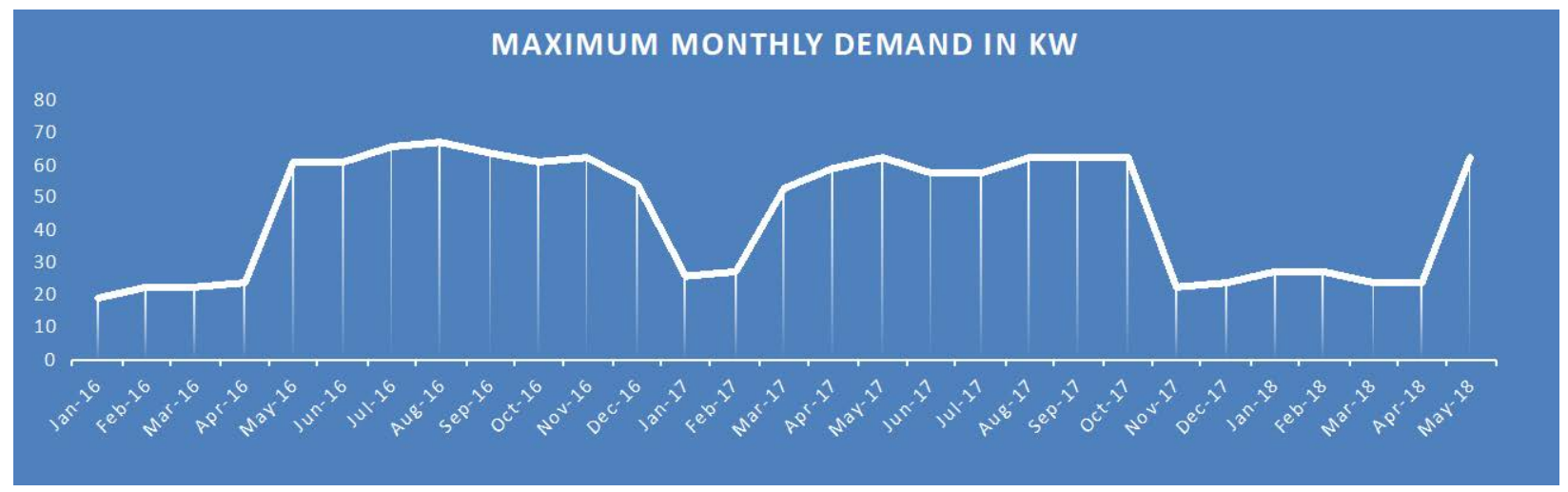

Figure 22. Fort Belvoir historical demand data for Building 187

Without accounting for power factor adjustments or efficiency losses, the $150 \mathrm{kVA}$ transformer had a spare capacity of only $83 \mathrm{~kW}$ for the EVSE and slightly less after accounting for the main distribution panel capacity (400 A). This capacity constraint limited the number of EVSE ports Fort Belvoir could install on the existing infrastructure. If the garrison wanted to install 18 simple EVSE ports next to Building 189 (in addition to the three by Building 187) (Figure 23), then they would need to upgrade their transformer and main distribution panel or select a managed charging solution.

A managed charging solution would permit the garrison to install a greater number of EVSE units on the existing equipment because the EVSE network would monitor the charging load. At times when the sum of the EVSE load and the historical facility peak load would exceed the transformer capacity, the charging system would limit the output of the EVSE to avoid exceeding the equipment ratings. This same concept may also be applied to monthly peak demand to mitigate demand load charges. 


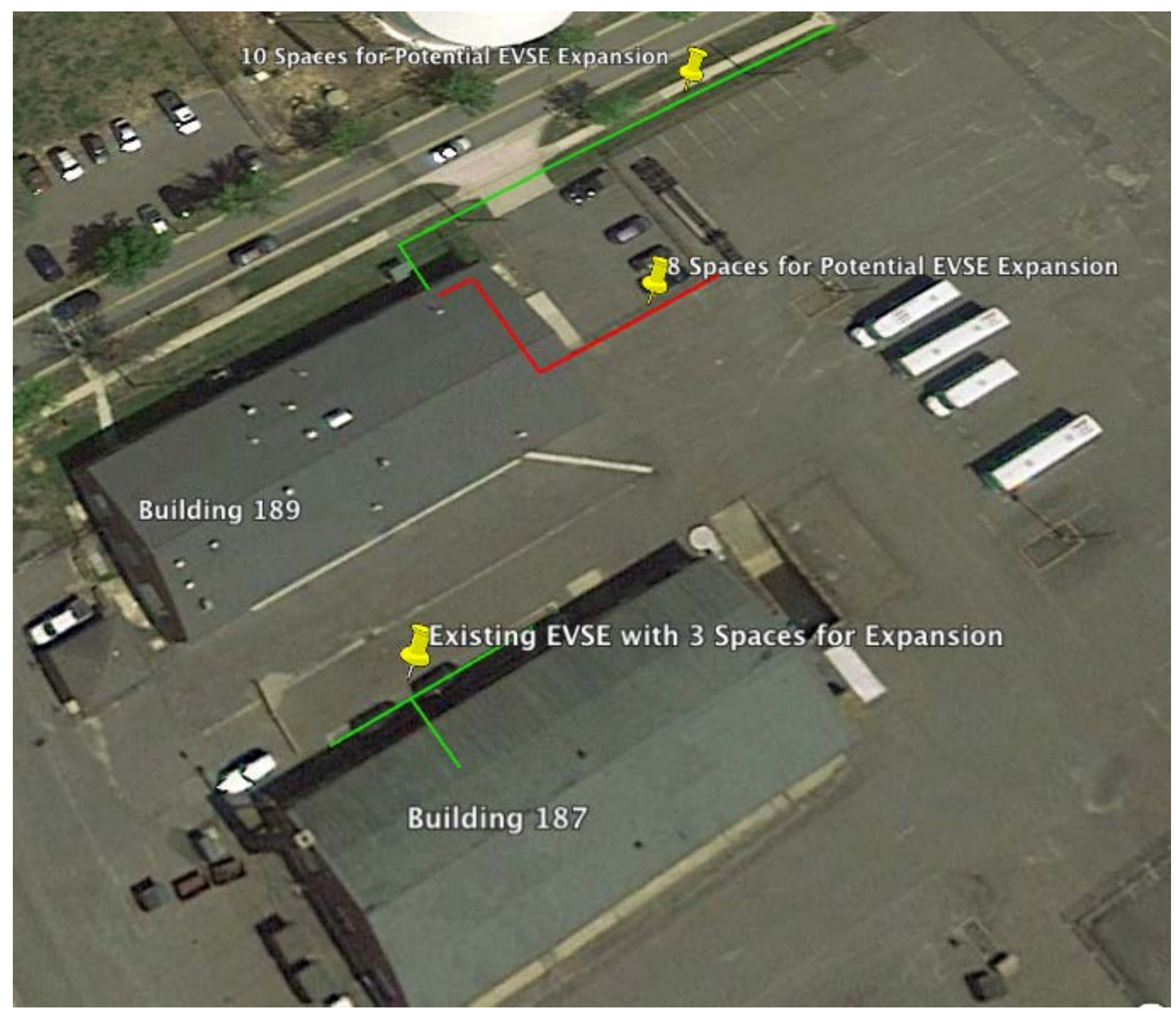

Figure 23. Overview of Fort Belvoir Buildings 189 and 187

(c) 2019 Google Earth, alterations by Cabell Hodge, NREL

In addition to equipment limitations, Fort Belvoir was also working with parking space considerations and wanted to minimize asphalt trenching. The installation of additional EVSE required that each unit was "smart" to accommodate managed charging and also required significant trenching. Both the incremental cost of smart EVSE units and the trenching through asphalt would add considerable costs to the project. The Tiger Team presented both options (Table 10) but noted that the unmanaged charging would be more affordable. 
Table 10. Fort Belvoir EVSE Recommendations

\begin{tabular}{|c|c|c|c|}
\hline Option & Description & Advantages & Drawbacks \\
\hline Option A & $\begin{array}{l}\text { Install new service panel and } \\
\text { eight basic Level } 2(32-A) \text { EVSE } \\
\text { ports along the grass northeast } \\
\text { of the building. }\end{array}$ & $\begin{array}{l}\text { Least expensive. Could } \\
\text { charge BEVs at full speed. }\end{array}$ & $\begin{array}{l}\text { Requires submeter to track } \\
\text { electricity consumption. } \\
\text { Limited to } 8 \text { EVSE ports. }\end{array}$ \\
\hline Option B & $\begin{array}{l}\text { Install } 18 \text { intelligent Level } 2 \text { (32- } \\
\text { A) EVSE ports: } 10 \text { along grass } \\
\text { and } 8 \text { along fence line. }\end{array}$ & $\begin{array}{l}\text { Could accommodate more } \\
\text { vehicles. Adaptive charging } \\
\text { allows more EVSE units than } \\
\text { 150-kVA transformer could } \\
\text { typically service. }\end{array}$ & $\begin{array}{l}\text { More expensive. May not be } \\
\text { necessary for planned EV } \\
\text { acquisitions in TMP. }\end{array}$ \\
\hline
\end{tabular}

\subsection{Level 1 EVSE}

In some cases, Level 1 EVSE made sense as a bridge for EVs. For example, Fort A.P. Hill expressed interest in placing an EV in the LRC parking lot, although they noted that most LRC vehicles were SUVs or pickup trucks. Considering the only SUV on the GSA schedule in 2018 was the Mitsubishi Outlander with a battery size of $12 \mathrm{kWh}$ at the time (increased to $13.8 \mathrm{kWh}$ in 2019), the existing $120 \mathrm{~V}$ receptacle on the utility pole in the parking lot would be sufficient to fully charge such a vehicle overnight (Figure 24).

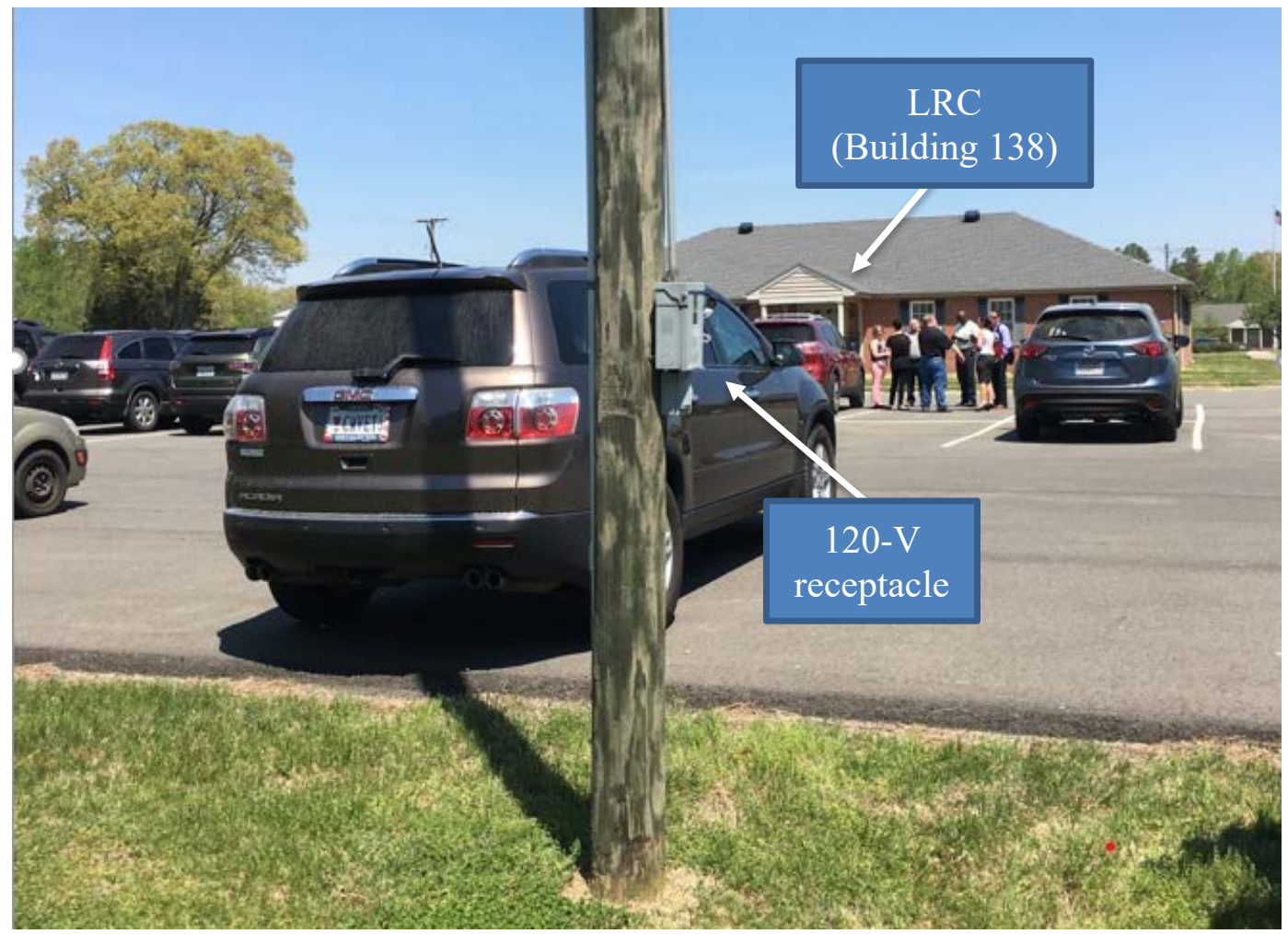

Figure 24. Level 1 receptacle at Fort A.P. Hill

Photo by Chuck Kurnik, NREL 
For EVs with larger batteries, Level 1 EVSE may not be sufficient. In some cases, Army garrisons had fixed Level 1 EVSE installed (Figure 24) to serve low-speed EVs (LSEVs) that could be replaced with Level 2 units. At Fort Hood, the Tiger Team recommended upgrading the Level 1 receptacles to Level 2 EVSE units.

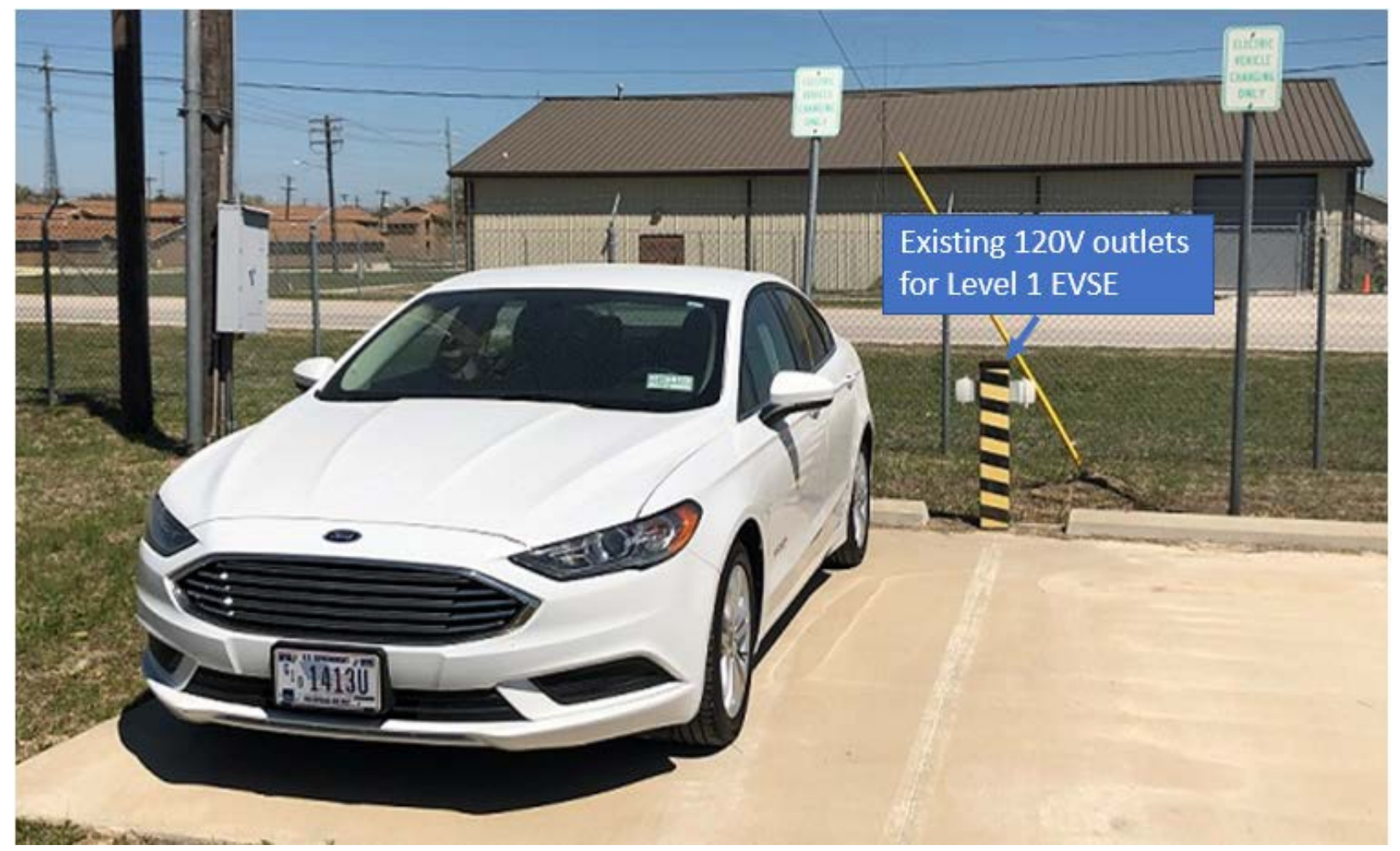

Figure 25. Dedicated parking space with existing Level 1 at North Fort Hood TMP Photo by Kosol Kiatreungwattana, NREL 


\section{CNG Assessment Results}

While the general scope of site assessments focused on EVs, HQDA expressed interest in candidate locations for CNG. Chief among these was Fort Jackson due to their large heavy-duty bus population used for troop transportation in support of their troop-training mission. In addition, some locations with large medium-duty vehicles were also good candidates for CNG options, such as Fort Campbell, Fort Polk, Fort Knox, Fort Sill, and Fort Bliss. NREL sent a CNG expert to Fort Jackson to make specific station recommendations, and the additional CNG candidates received general recommendations for CNG fueling.

\subsection{Summary of CNG Assessments}

Fort Jackson's troop-training mission included a directive to increase the number of trainees from 40,000 to 60,000 in coming years, with plans to replace school buses with troop carriers pulled by Class 8 tractors. These Class 8 tractors could be operated with a CNG engine providing fuel diversity and lower fuel costs compared to a conventional diesel engine. In addition to EV replacement plans for LD EVs, HQDA is planning to build a CNG station at Fort Jackson in the TMP yard. The Tiger Team tried to ascertain the location of high-pressure natural gas lines that could supply the TMP with CNG and recommended logistics for the station itself. Figure 26 shows the location of a high-pressure natural gas connection near the TMP lot, and Figure 27 diagrams a potential CNG station design. The design would require a new ingress and egress for the buses.

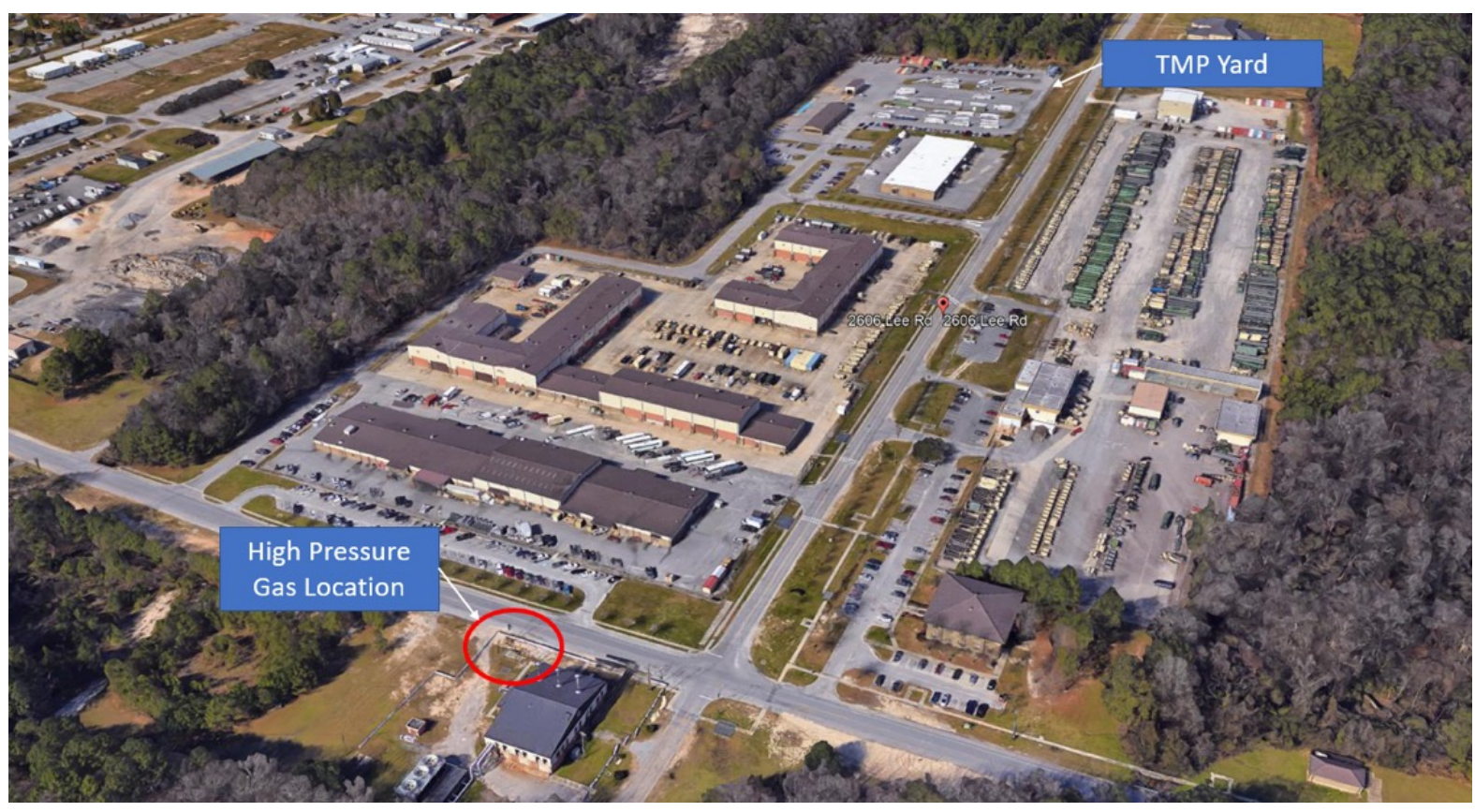

Figure 26. TMP yard and high-pressure gas location at Fort Jackson

(C) 2019 Google Earth, alterations by Lauren Lynch and John Gonzales, NREL 


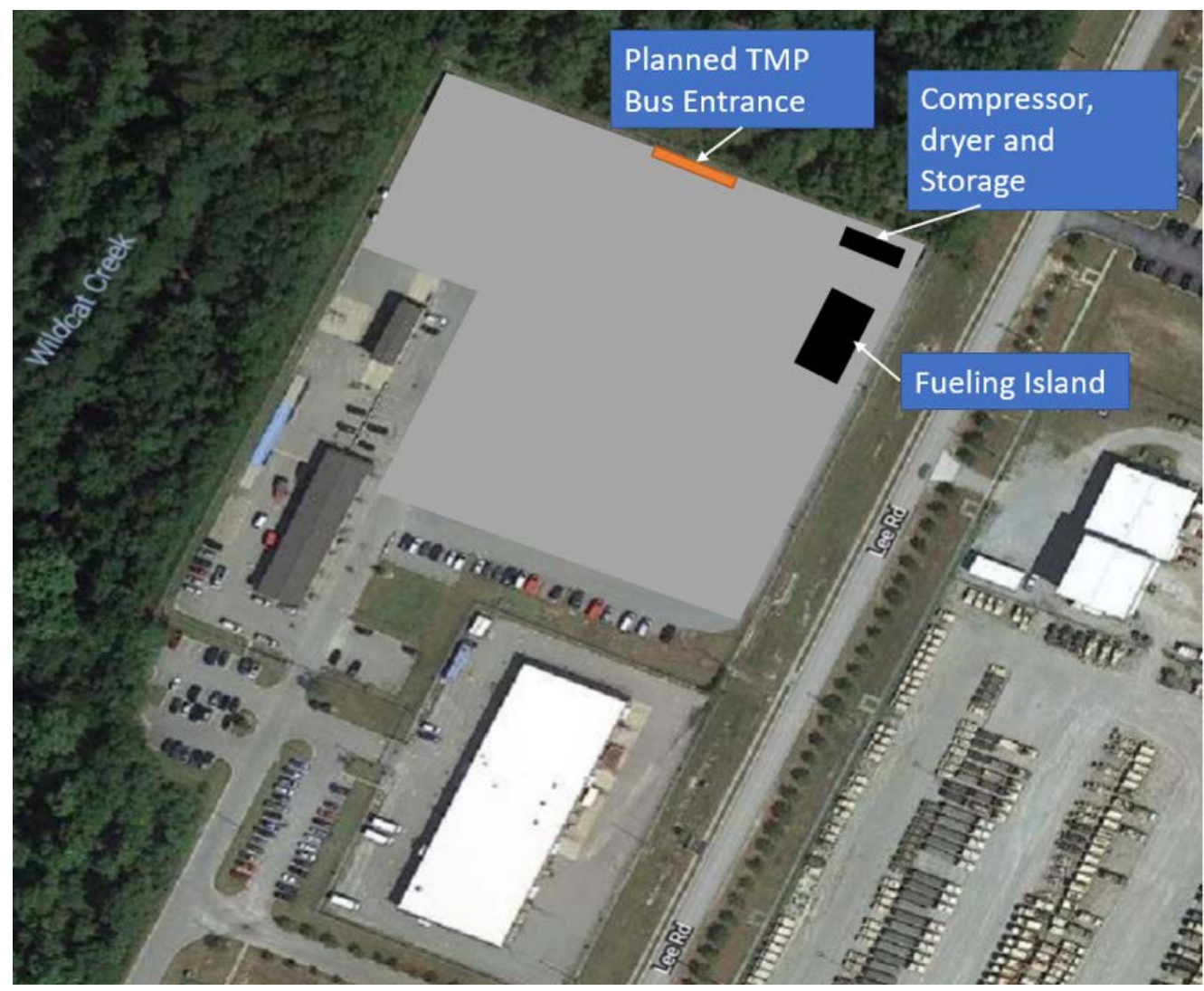

Figure 27. CNG station blueprint at Fort Jackson

(C) 2019 Google Earth, alterations by Lauren Lynch and John Gonzales, NREL

Fort Campbell had 22 heavy-duty diesel buses and 281 medium-duty passenger and vocational trucks, all of which were potential candidates for CNG dedicated or dual-fuel vehicle replacements. Fort Campbell's medium-duty vehicles were great candidates for dual-fuel vehicles as the combined fuel system of CNG and diesel improves the fuel economy without any impacts to the range capability and would diversify the fuel type of the overall fleet to improve energy resiliency. Fort Campbell's existing vehicle fuel yard located on the installation had enough space and assumed electrical infrastructure to support a CNG fueling station as shown below in Figure 28. Therefore, the Tiger Team recommended Fort Campbell as a candidate for a CNG fueling station and future dual-fuel vehicle acquisitions. 


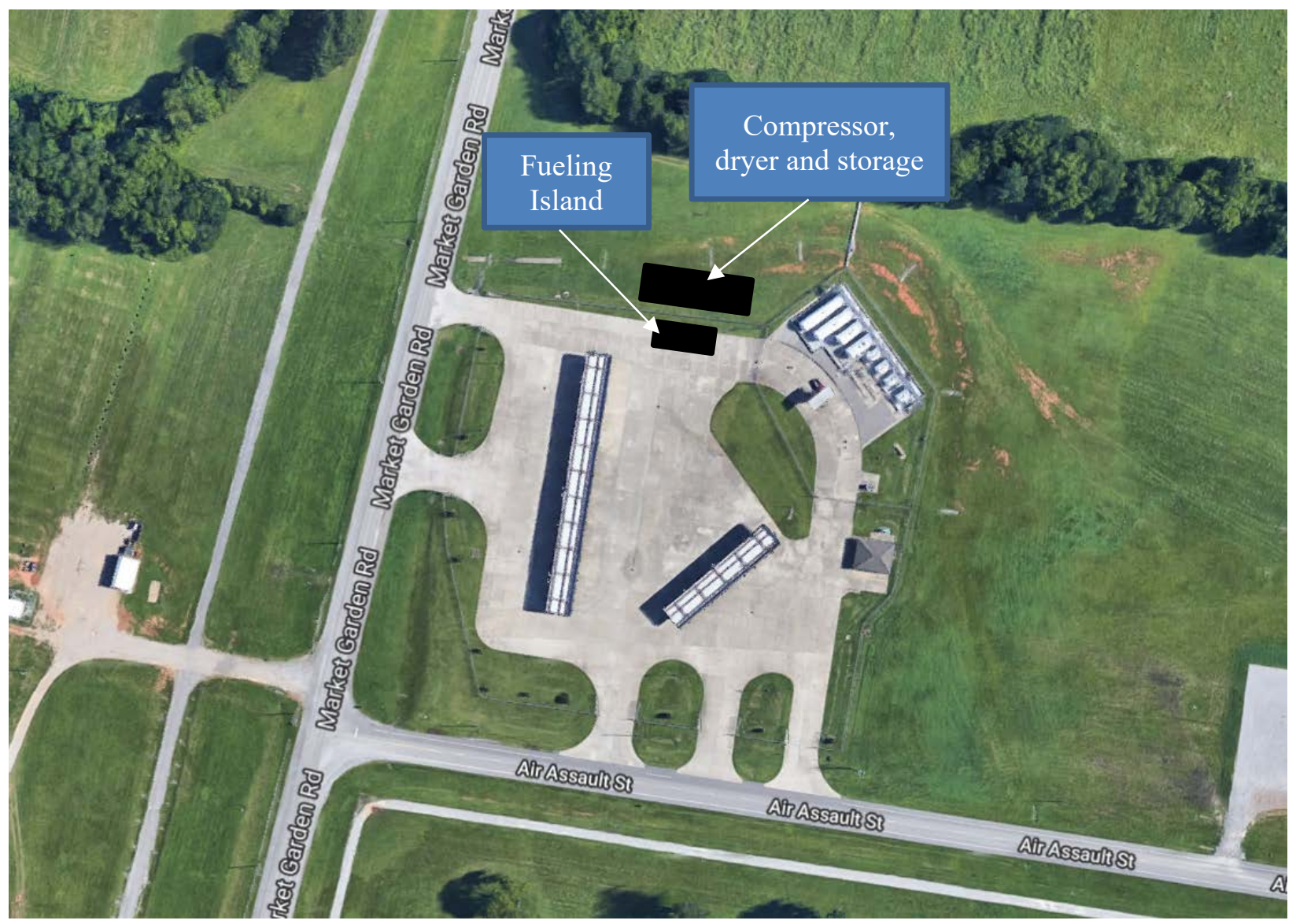

Figure 28. TMP aerial view with CNG station location recommendations

(C) 2019 Google Earth, alterations by Lauren Lynch and John Gonzales, NREL

\subsection{Station Considerations}

A typical CNG station comprises multiple components in a common sequence, typically including an inlet gas dryer, compressor(s), gas metering panel (generally called a priority panel), storage vessel system, and gas dispenser (Figure 29).

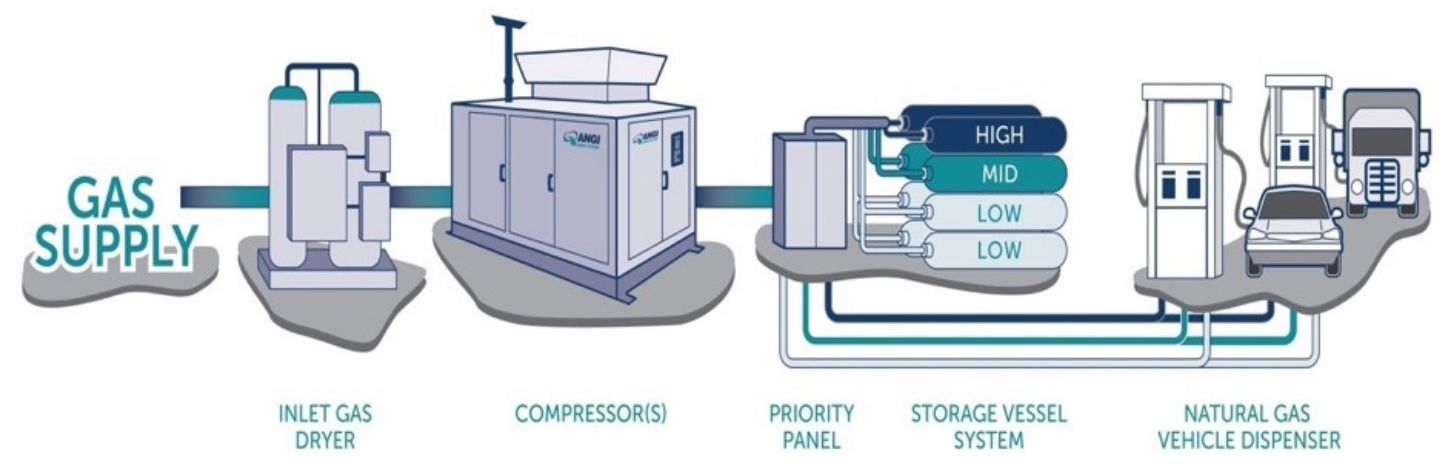

Figure 29. Schematic of basic CNG station components

Illustration by ANGI Energy Systems, NREL 
Inlet gas dryers are designed to lower the overall moisture content of the gas stream for powering NGVs. Pipeline specifications require natural gas to contain no more than $7 \mathrm{lbs}$ of water per million standard cubic feet, which is sufficient for standard household operations such as heating with gas furnaces and water heaters. However, NGV fueling requires dryer gas than the pipeline specification. Most CNG stations utilize an inlet gas dryer to further reduce the moisture to meet this requirement.

Natural gas compressors transfer gas from the local supply pipeline to onsite storage or directly to a vehicle. For heavy-duty vehicle fueling, a compressor transfers gas from the supply pipeline to tanks for onsite storage. When fueling a heavy-duty vehicle, the fuel from the storage tanks will first be transferred to the vehicle, and then the compressor will transfer gas from the supply pipeline directly to the vehicle once the onsite storage is depleted. The compressor then refills the storage tanks in preparation for the next fueling. Fleet requirements dictate how much compressor throughput is needed. In most cases, the site should have two compressors, which enables uninterrupted fueling when one compressor is turned off for maintenance and provides a backup compressor in case of mechanical failure. Figure 30 shows two compressors at a CNG station.

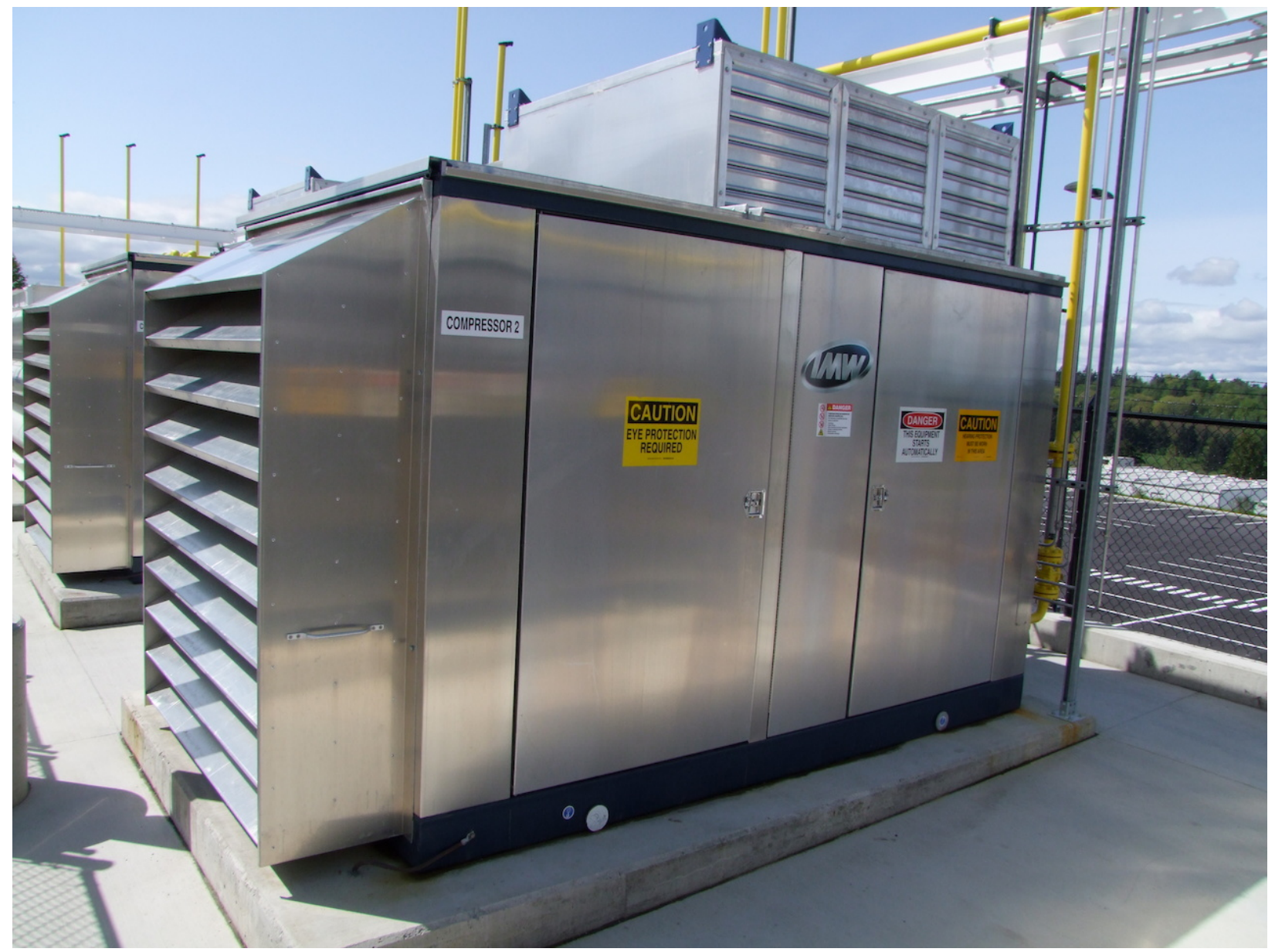

Figure 30. Two compressors at a CNG station

Photo by Marathon Technical Services, NREL 
A gas metering or priority panel transfers gas from the compressor and determines the best path for the high-pressure gas to be delivered. If there are no vehicles or the storage can provide ample fuel to the vehicle, then the compressor fills directly to storage. If storage is depleted and cannot adequately fill the vehicle, then the compressor begins filling the vehicle directly.

Natural gas is stored onsite in storage vessels or storage spheres. This onsite storage allows vehicles to fuel like a retail fueling station. To maximize the pressure differential required to fuel NGVs, three banks of storage are used: low, mid, and high pressure (Figure 31).

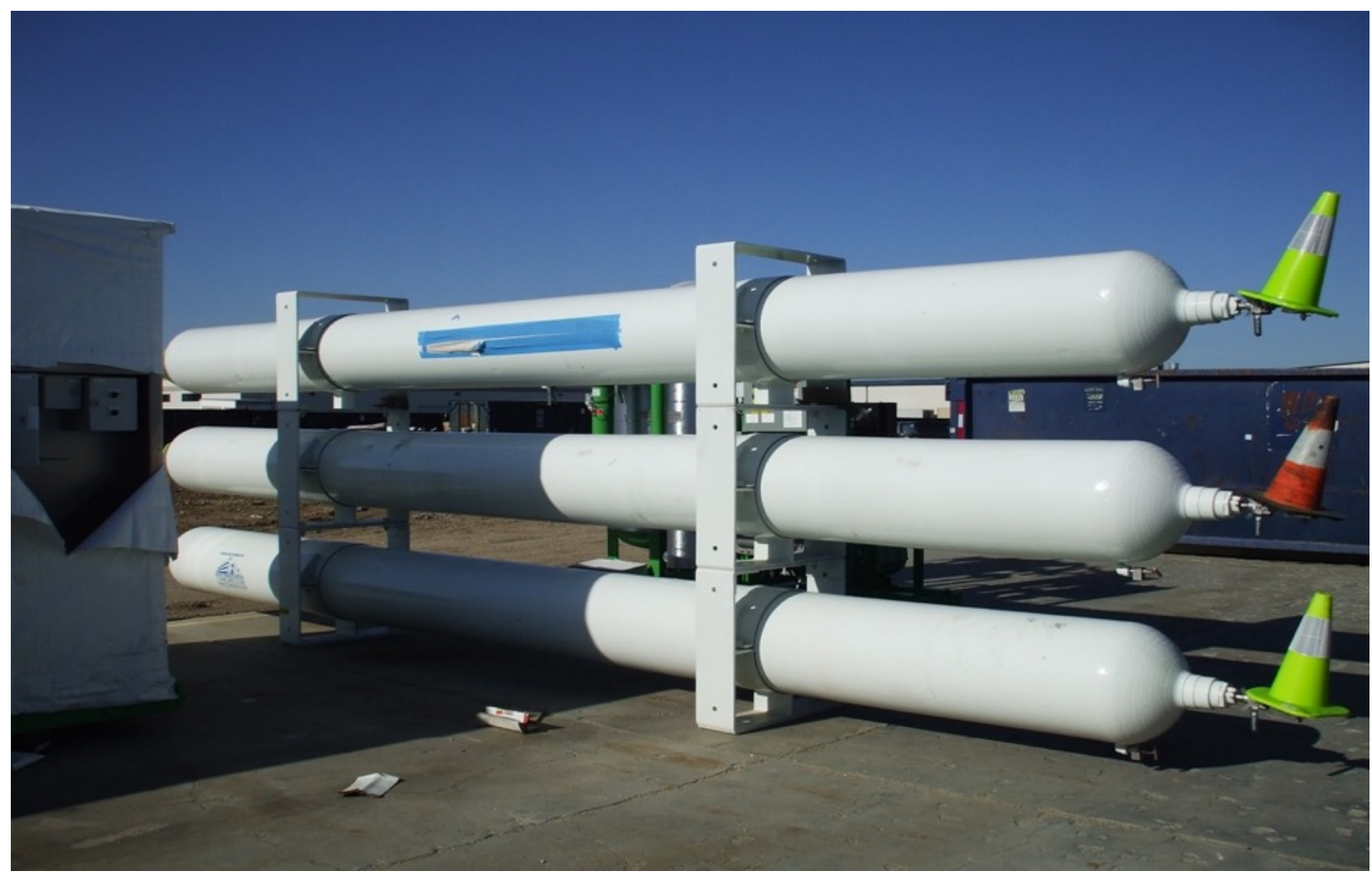

Figure 31. CNG storage vessels with three banks

Photo by Beth Baird, NREL

The vehicle dispenser is the final CNG station component, transferring high-pressure gas from the storage system or compressor, via the priority panel, to the vehicle. It is typically equipped with a card reader similar to standard gasoline and diesel card readers.

In addition to these components, a CNG fueling station should have a canopy and lighting to protect operators from bad weather and to increase nighttime safety. Figure 32 shows a CNG fueling station with all of these components. 


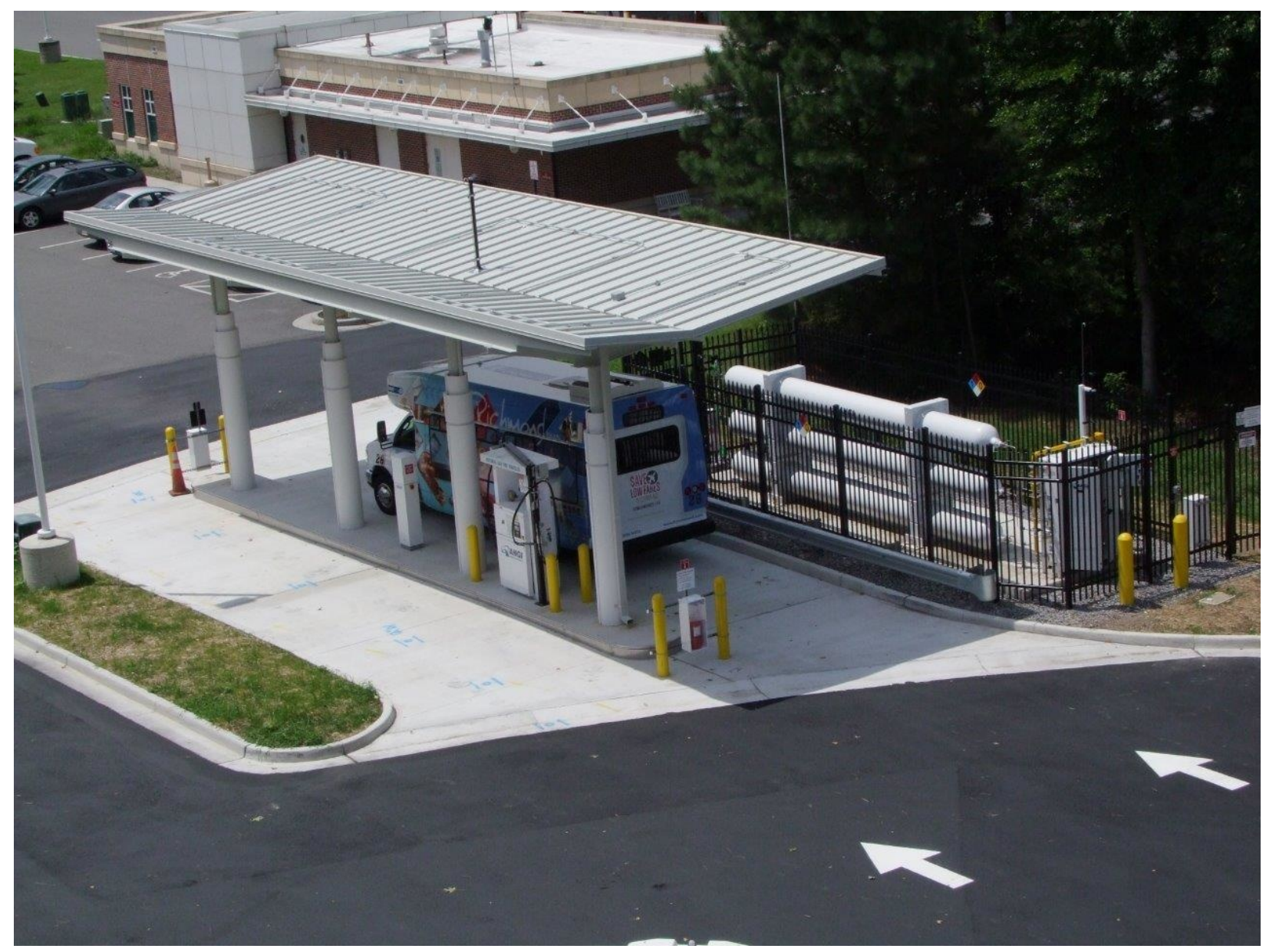

Figure 32. Example of a basic CNG fueling station

Photo by Marathon Technical Services, NREL 


\section{Conclusion}

This project comprised site visits to 30 Army garrisons, 29 of which proved to be prime candidates for EVSE. The lone garrison that would not benefit from EVSE in the short term, Fort Campbell, was nevertheless a good candidate for CNG. The majority of these new EVSE units will be installed to enable EV fleet expansion, while some will serve the fueling needs of existing EVs. Additionally, although each site had specific needs and requirements, most recommendations included either a new subpanel or the installation of a new utility service point. After installing its first Level 2 EVSE units, most garrisons should develop enough knowledge to conduct its own site assessments moving forward.

These upgrades will enable the 29 sites to house a total of 252 Level 2 EVSE ports to serve an anticipated $236 \mathrm{EVs}$ in the next three to five years and additional acquisitions in future years. Each of these site visits, as well as the detailed recommendations from the Tiger Teams, are displayed in the table under Appendix B.

Throughout this process, the EV market in the United States has continued to grow, and the GSA schedule offerings have added multiple BEVs, as well as PHEV 4x4 SUV and minivan options. These vehicles have continued to prove themselves as viable alternatives to gasoline-powered vehicles in the LD sector. The performance and range of EVs has greatly improved from LSEVs limited to $25 \mathrm{mph}$ speeds, which were previously the only plug-in electric vehicle options available. This is most notable in the aggressive adoption plans some garrisons indicated for their EV fleet, such as the increase from 3 to 50 EVs that Fort McCoy anticipates will occur in the next five years.

As the U.S. Army grows its EV fleet and continues to adopt both BEVs and PHEVs, the EVSE installations recommended in this report will enable a smooth transition. This transition will improve fleet efficiency, and it will reduce petroleum consumption, fueling costs, and vehicle maintenance. These new units will probably not be the last EVSE installed at these locations. The continued growth of the EV fleet will require additional infrastructure and more advanced solutions to new challenges that will arise.

Over the past several years, the CNG market has transitioned away from sedans toward larger vehicles. Training transport vehicles are an excellent application for CNG due to their predictable routes, high utilization rates on or near bases, and the fuel consumption rates of the transport vehicles.

\subsection{General Recommendations}

In addition to the specific locational analyses described above, the following recommendationsbased on the Tiger Teams' experience guiding EVSE decisions - can help the Army save on EVSE installations across the country:

- Install EVSE and CNG stations close to utility service connections. Trenching is often the most expensive element of an EVSE installation and may damage parking areas even after remediating the trench. Transformers and overhead conductors require additional expenditures as well, and longer electrical runs require thicker gauge wire to minimize voltage drop. Installing new high pressure natural gas pipelines can be quite expensive as 
well, and if sufficient gas is not available, the cost to install a CNG station at that location can be prohibitive.

- Plan for the future when sizing infrastructure. Whenever new or additional electrical infrastructure is required to support EVSE, the design team and the garrison should plan for future growth. This may include additional capacity in the transformer and service panel, a larger conduit size, or pre-stubbed spots for additional EVSE units.

- Consider what EVSE features are necessary for the application. EVSE units can capture data, restrict access, process transactions, and manage power demand. However, these features all incur additional costs and may not be necessary in all cases. For example, a separate exterior meter can disaggregate vehicle electricity use from other uses, a fenced-in parking lot can limit access, transaction processing is not necessary for fleet applications, and a limited number of EVSE units may not require power management.

- Install EVSE in between parking spots rather than directly in front of vehicles where applicable. This is clearly the preference for dual-port units, but it is also preferable for single-port units. It allows multiple EVs to use the same EVSE, creates an additional EV parking spot for when an internal combustion engine vehicle is parked in the EV-designated spot and reduces the likelihood of vehicles colliding with the EVSE.

- Consider installing lighting near EVSE for security and convenience. Lighting is an important consideration for EVSE units where drivers may park in the evening or access vehicles in the early morning. Any plans to install EVSE should consider the safety and security of drivers by installing LED lighting when necessary. This will most likely require additional service panel capacity to accommodate a $120 \mathrm{~V}$ single pole breaker.

- Integrate EVSE planning into the master planning process and construction planning. The best time to install EVSE is while the area is being disturbed by construction, rather than as an afterthought. At a minimum, an area can be made EVSE ready, which includes installing conduits from the closest electrical infrastructure to the planned future EVSE location and sizing electrical infrastructure for the additional load of EV charging. The garrison should integrate EVSE into the master planning process so it is captured as construction plans move forward.

- Collaborate with local utilities. Many utilities have programs to support EVSE installation financially or with technical expertise. ${ }^{1}$ Utilities will often upgrade transformers at no cost to Army garrisons, although the upgrades may be incorporated in later increases to electricity rates. In addition, the utilities often have information about electrical and natural gas service that may not be available to garrisons.

\subsection{Next Steps}

This initial phase of EVSE installations addressed the charging needs of garrisons beginning to adopt EVs. However, if the EV growth from the Argonne market report in Figure 1 continues, the sites visited will likely continue installing EVSE, and additional garrisons will need to install

\footnotetext{
${ }^{1}$ Edison Electric Institute compiled a list of EV-related regulatory filings by investor owned utilities at https://www.eei.org/issuesandpolicy/electrictransportation/Documents/FINAL_ET\%20Biannual\%20State\%20Regul atory\%20Update_May\%202019.pdf.
} 
EVSE as well. Those involved with installations at initial sites can act as ambassadors, and DOE FEMP offers resources such as EVSE site assessment training courses that could benefit later adopters.

Because the Army may only install one or two CNG stations in the near future and CNG stations are much more expensive than EVSE, NREL recommends consulting with experts before developing CNG installation plans.

As EVs are adopted in larger numbers, peak demand concerns will become a greater challenge, which will likely require close collaboration with the local utility. During this time, employees will also be looking for workplace charging options to charge their POVs during the day. These challenges will require more EVSE with advanced networking features for managed charging, access control, and transaction processing. They could also benefit from communication with local facility management systems to not only reduce peak demand, but also potentially structure dynamic rates for POVs that incentivize charging during times when facility demand is low.

Integration with facility management systems may introduce cybersecurity concerns and will require consideration of Army's Risk Management Framework and Authority to Operate. NREL has researched EVSE cybersecurity concerns ${ }^{2}$ and published a report, "Vehicle Cybersecurity Threats and Mitigation Approaches," that addresses these challenges (Hodge, Hauck, Gupta, and Bennett 2019). Although these challenges did not appear during this project, they will likely become apparent as the EV fleet continues to grow. Current technology is well equipped to handle these challenges and can be implemented as soon as they arise.

EVSE installation is a key component to successful EV deployment. Minimizing unit and installation costs are important factors in achieving a positive return on investment for the vehicles. However, it is critical to select EVSE features that support the site's needs, constraints, and long-term goals.

\footnotetext{
${ }^{2}$ See the Federal Energy Management Program's Federal Fleet Cybersecurity website: https://www.energy.gov/eere/femp/federal-fleet-cybersecurity.
} 


\section{References}

Argonne National Laboratory. n.d. "Light Duty Electric Drive Vehicles Monthly Sales Updates." Accessed September 2019. https://www.anl.gov/es/light-duty-electric-drive-vehicles-monthlysales-updates.

Chevrolet. n.d. "Bolt EV.” Accessed November 2018.

https://www.chevrolet.com/electric/bolt-ev-electric-car.

DOE (U.S. Department of Energy). 2015. Costs Associated With Non-Residential Electric

Vehicle Supply Equipment. Washington, DC: Prepared by New West Technologies, LLC, for the U.S. Department of Energy Vehicle Technologies Office. DOE/EE-1289.

https://afdc.energy.gov/files/u/publication/evse cost report 2015.pdf.

Fueleconomy.gov. 2019. “Compare Side-by-Side: 2019 Chevrolet Bolt EV.” Accessed July 2019. https://www.fueleconomy.gov/feg/Find.do?action=sbs\&id=40520.

Hodge, Cabell, Konrad Hauck, Shivam Gupta, and Jesse Bennett. 2019. Vehicle Cybersecurity Threats and Mitigation Approaches. Golden, CO: National Renewable Energy Laboratory. NREL/TP-5400-74247. https://www.nrel.gov/docs/fy19osti/74247.pdf.

U.S. President. Executive Order. "Efficient Federal Operations, Executive Order 13834 of May 17, 2018." Federal Register 83, no. 99 (May 22, 2018): 23771. https://www.govinfo.gov/content/pkg/FR-2018-05-22/pdf/2018-11101.pdf.

U.S. President. Executive Order. "Planning for Federal Sustainability in the Next Decade, Executive Order 13693 of March 19, 2015." Federal Register 80, no. 57 (March 25, 2015): 15871. https://www.govinfo.gov/content/pkg/FR-2015-03-25/pdf/2015-07016.pdf. 


\section{Appendix A. Questionnaire and Checklist}

\section{Federal Fleet EVSE Tiger Team \\ Questionnaire for Federal Fleet EVSE Planning}

[LOCATION SHORT NAME]

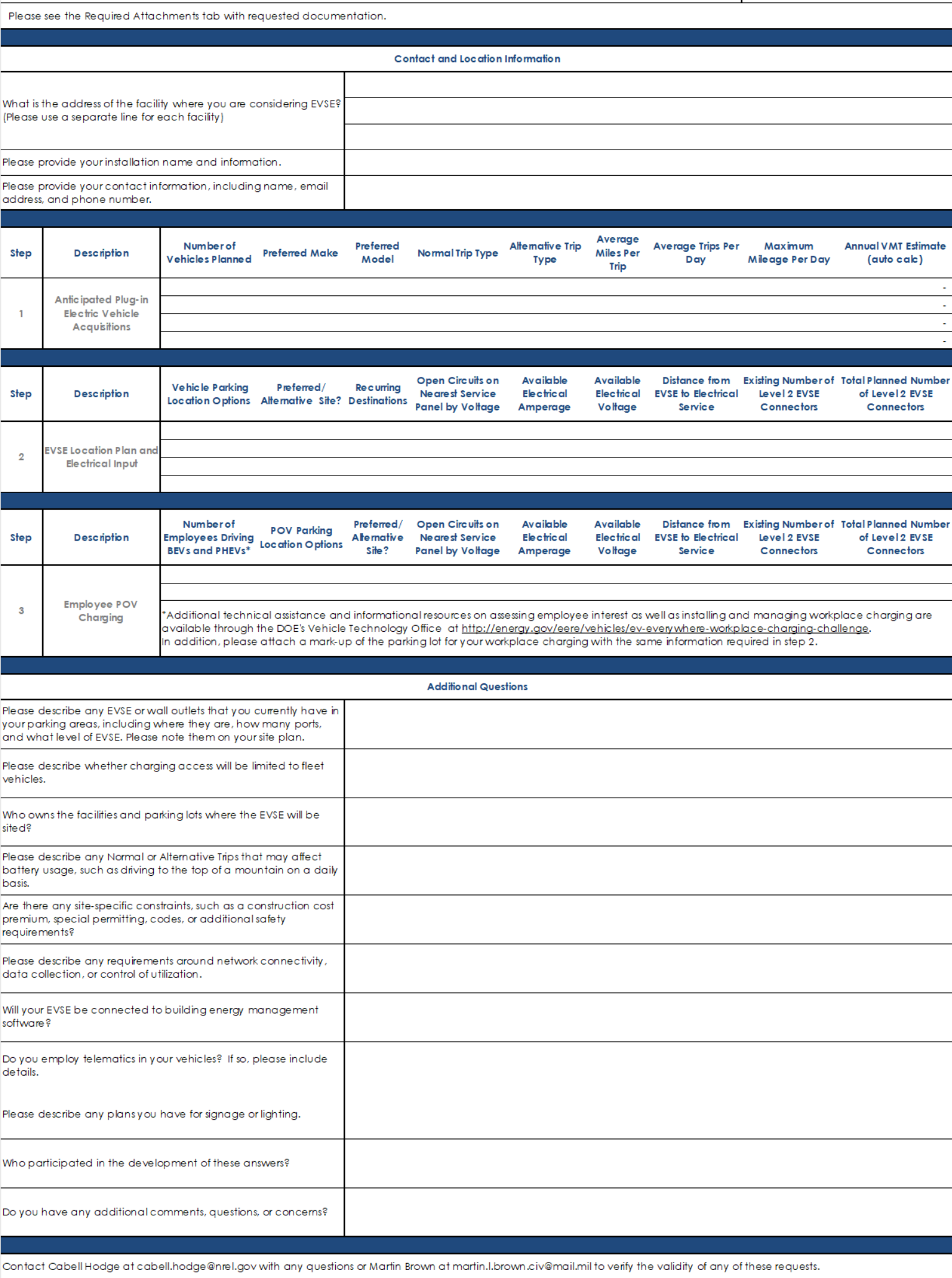

This report is available at no cost from the National Renewable Energy Laboratory at www.nrel.gov/publications. 


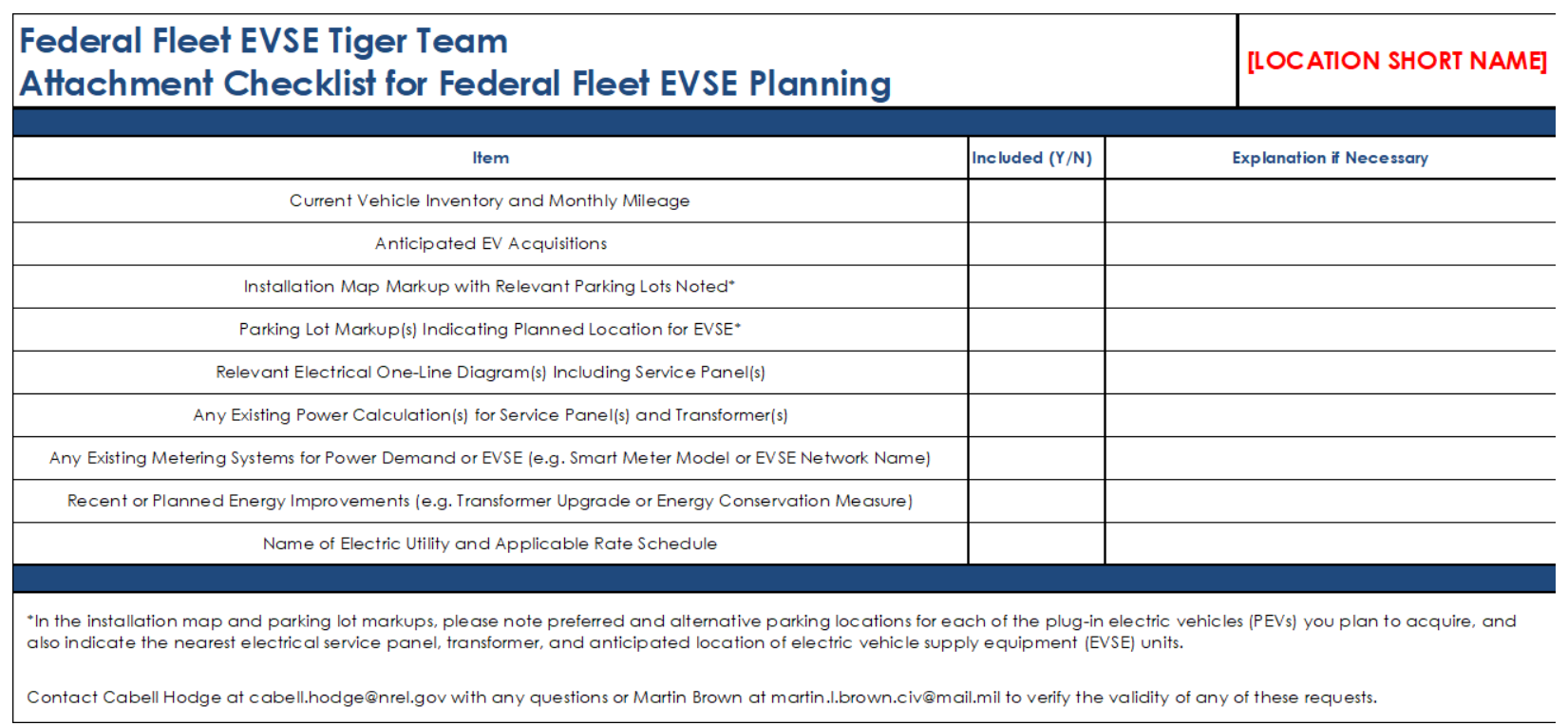




\section{Appendix B. List of Tiger Team Site Assessment Recommendations}

\begin{tabular}{|c|c|c|c|c|c|c|c|}
\hline Location & $\begin{array}{l}\text { Electrical } \\
\text { Access Point }\end{array}$ & $\begin{array}{l}\text { Proposed } \\
\text { Transformer }\end{array}$ & $\begin{array}{l}\text { Secondary } \\
\text { Voltage }\end{array}$ & $\begin{array}{l}\text { Electrical } \\
\text { Run }\end{array}$ & $\begin{array}{l}\text { Panel } \\
\text { Upgrades }\end{array}$ & $\begin{array}{l}\text { Recommended Concept } \\
\text { Design }\end{array}$ & $\begin{array}{l}\text { EVSE Type and } \\
\text { Quantity }\end{array}$ \\
\hline $\begin{array}{l}\text { AP Hill } \\
\text { DPW }\end{array}$ & $\begin{array}{l}\text { Pole-mount } \\
\text { transformer in } \\
\text { parking lot }\end{array}$ & 50 kVA & $208 / 120 \mathrm{~V}$ & $\begin{array}{l}55^{\prime} \text { overhead } \\
30 \text { ' trench }\end{array}$ & $\begin{array}{l}\text { Install new } \\
\text { service with } \\
\text { outdoor } \\
\text { service panel }\end{array}$ & $\begin{array}{l}\text { Run overhead conductors } \\
\text { from transformer to light } \\
\text { pole; install new meter, } \\
\text { subpanel, and EVSE on } \\
\text { post/strut channel }\end{array}$ & $\begin{array}{l}1 \text { dual-port Level } \\
2 \text { wall-mount unit } \\
\text { (2 total ports) }\end{array}$ \\
\hline $\begin{array}{l}\text { AP Hill } \\
\text { TMP }\end{array}$ & $\begin{array}{l}\text { Pole-mount } \\
\text { transformer near } \\
\text { building }\end{array}$ & $50 \mathrm{kVA}$ & $208 / 120$ V & 130 ' trench & $\begin{array}{l}\text { Install new } \\
\text { service }\end{array}$ & $\begin{array}{l}\text { Run conductors from pole- } \\
\text { mount transformers to meter } \\
\text { to outdoor subpanel; trench } \\
\text { through grass and asphalt to } \\
\text { parking area }\end{array}$ & $\begin{array}{l}2 \text { dual-port Level } \\
2 \text { pedestal units } \\
\text { (4 total ports) }\end{array}$ \\
\hline $\begin{array}{l}\text { AP Hill } \\
\text { LRC }\end{array}$ & $\begin{array}{l}\text { Light pole on } \\
\text { south side of } \\
\text { parking lot }\end{array}$ & & $120 / 240 \mathrm{~V}$ & & & $\begin{array}{l}\text { Use existing } 120-V \\
\text { receptacle to plug in } \\
\text { standard vehicle cord set. }\end{array}$ & Level 1 cord set \\
\hline Aberdeen & $\begin{array}{l}\text { Transformers by } \\
\text { DPW and } \\
\text { Garrison HQ lots }\end{array}$ & & & $\begin{array}{l}5^{\prime} \text { by } \mathrm{DPW} \\
\text { and } 20^{\prime} \text { by } \\
\text { Garrison } \mathrm{HQ}\end{array}$ & $\begin{array}{l}\text { Install new } \\
\text { service }\end{array}$ & $\begin{array}{l}\text { Tap transformers and install } \\
\text { new meter, panel, and } \\
\text { pedestal EVSE }\end{array}$ & $\begin{array}{l}2 \text { dual-port Level } \\
2 \text { pedestal units }\end{array}$ \\
\hline $\begin{array}{l}\text { Belvoir } \\
\text { Building } 189\end{array}$ & $\begin{array}{l}\text { Main Distribution } \\
\text { Panel (MDP) }\end{array}$ & 150 kVA & $208 / 120 \mathrm{~V}$ & 200 ' trench & $\begin{array}{l}\text { Install a new } \\
\text { branch } \\
\text { service panel } \\
\text { from the MDP }\end{array}$ & $\begin{array}{l}\text { Install electrical run from } \\
\text { interior MDP to new } \\
\text { subpanel, run conductors } \\
\text { outside building to parking } \\
\text { spaces along grass }\end{array}$ & $\begin{array}{l}4 \text { dual-port Level } \\
2 \text { pedestal units } \\
\text { (8 total ports) }\end{array}$ \\
\hline $\begin{array}{l}\text { Bliss } \\
\text { Building } \\
2607 \text { TMP }\end{array}$ & Service panel & & $120 / 240 \mathrm{~V}$ & & $\begin{array}{l}\text { Upgrade } \\
\text { service panel }\end{array}$ & $\begin{array}{l}\text { Upgrade existing panel and } \\
\text { install new exterior subpanel } \\
\text { off of existing panel, meter, } \\
\text { and wall-mounted EVSE }\end{array}$ & $\begin{array}{l}1 \text { dual-port Level } \\
2 \text { wall-mount unit } \\
\text { ( } 2 \text { total ports) }\end{array}$ \\
\hline
\end{tabular}




\begin{tabular}{|c|c|c|c|c|c|c|c|}
\hline Location & $\begin{array}{l}\text { Electrical } \\
\text { Access Point }\end{array}$ & $\begin{array}{l}\text { Proposed } \\
\text { Transformer }\end{array}$ & $\begin{array}{l}\text { Secondary } \\
\text { Voltage }\end{array}$ & $\begin{array}{l}\text { Electrical } \\
\text { Run }\end{array}$ & $\begin{array}{l}\text { Panel } \\
\text { Upgrades }\end{array}$ & $\begin{array}{l}\text { Recommended Concept } \\
\text { Design }\end{array}$ & $\begin{array}{l}\text { EVSE Type and } \\
\text { Quantity }\end{array}$ \\
\hline $\begin{array}{l}\text { Bliss } \\
\text { Division } \mathrm{HQ}\end{array}$ & $\begin{array}{l}\text { Pad mount } \\
\text { three-phase } \\
\text { transformer }\end{array}$ & 75 kVA & $480 / 277 \mathrm{~V}$ & & $\begin{array}{l}\text { Install new } \\
\text { service panel }\end{array}$ & $\begin{array}{l}\text { Install stepdown } \\
\text { transformer, new exterior } \\
\text { subpanel, meter, and } \\
\text { pedestal-mounted EVSE. }\end{array}$ & $\begin{array}{l}1 \text { dual-port Level } \\
2 \text { wall-mount unit } \\
\text { ( } 2 \text { total ports) }\end{array}$ \\
\hline $\begin{array}{l}\text { Bliss } \\
\text { Garrison } \mathrm{HQ}\end{array}$ & $\begin{array}{l}\text { Pole mount } \\
\text { three-phase } \\
\text { transformer } \\
\text { bank }\end{array}$ & & $480 / 277 \mathrm{~V}$ & & $\begin{array}{l}\text { Install new } \\
\text { service panel }\end{array}$ & $\begin{array}{l}\text { Install stepdown } \\
\text { transformer, new exterior } \\
\text { subpanel, meter, and } \\
\text { pedestal-mounted EVSE. }\end{array}$ & $\begin{array}{l}1 \text { dual-port Level } \\
2 \text { wall-mount unit } \\
\text { ( } 2 \text { total ports) }\end{array}$ \\
\hline $\begin{array}{l}\text { Carson } \\
\text { Building } 749\end{array}$ & $\begin{array}{l}\text { Pad mount } \\
\text { three-phase } \\
\text { transformer }\end{array}$ & 300 kVA & $480 / 277 \mathrm{~V}$ & 250 ' trench & $\begin{array}{l}\text { Install new } \\
\text { service with } \\
\text { 400-A service } \\
\text { panel }\end{array}$ & $\begin{array}{l}\text { New service tap off } \\
\text { distribution transformer with } \\
\text { step-down transformer to } \\
\text { supply } 120 / 240 \text { V to EVSE. }\end{array}$ & $\begin{array}{l}3 \text { dual-port Level } \\
2 \text { pedestal units } \\
(6 \text { ports total) }\end{array}$ \\
\hline $\begin{array}{l}\text { Carson } \\
\text { Building } \\
8000\end{array}$ & $\begin{array}{l}\text { Pad mount } \\
\text { three-phase } \\
\text { transformer }\end{array}$ & $1,500 \mathrm{kVA}$ & $480 / 277 \mathrm{~V}$ & 200 ' trench & $\begin{array}{l}\text { Install new } \\
\text { service with } \\
400-A \text { service } \\
\text { panel }\end{array}$ & $\begin{array}{l}\text { New service tap off } \\
\text { distribution transformer with } \\
\text { step-down transformer to } \\
\text { supply } 120 / 240 \text { V to EVSE. }\end{array}$ & $\begin{array}{l}3 \text { dual-port Level } \\
2 \text { pedestal units } \\
(6 \text { ports total) }\end{array}$ \\
\hline $\begin{array}{l}\text { Gordon } \\
\text { TMP }\end{array}$ & $\begin{array}{l}\text { No nearby } \\
\text { transformer }\end{array}$ & 75 kVA & $208 / 120 \mathrm{~V}$ & 120 ' trench & $\begin{array}{l}\text { Install new } \\
\text { service }\end{array}$ & $\begin{array}{l}\text { Request new service off new } \\
\text { transformer from Georgia } \\
\text { Power. }\end{array}$ & $\begin{array}{l}5 \text { dual-port Level } \\
2 \text { pedestal units } \\
\text { (10 ports total) }\end{array}$ \\
\hline $\begin{array}{l}\text { Gordon } \\
\text { SSC-SF }\end{array}$ & $\begin{array}{l}\text { MDP in Building } \\
35203\end{array}$ & & $208 / 120 \mathrm{~V}$ & 95' trench & $\begin{array}{l}\text { Install indoor } \\
\text { subpanel from } \\
\text { MDP }\end{array}$ & $\begin{array}{l}\text { Install subpanel, drill through } \\
\text { concrete wall, trench } \\
\text { through grass and install } \\
\text { pad. }\end{array}$ & $\begin{array}{l}1 \text { dual-port Level } \\
2 \text { pedestal unit }(2 \\
\text { ports total) }\end{array}$ \\
\hline $\begin{array}{l}\text { Hood } \\
\text { TMP }\end{array}$ & $\begin{array}{l}\text { Existing utility } \\
\text { service at north } \\
\text { east of TMP } \\
\text { office }\end{array}$ & & $208 / 120 \mathrm{~V}$ & $\begin{array}{l}200 \\
\text { overhead } \\
30 \text { ' trench }\end{array}$ & & $\begin{array}{l}\text { Connect existing line with } \\
\text { underground electrical run } \\
\text { through boring and trenching } \\
\text { under asphalt to meter, } \\
\text { subpanel, and EVSE unit. }\end{array}$ & $\begin{array}{l}2 \text { dual-port Level } \\
2 \text { pedestal units } \\
\text { (4 ports total) }\end{array}$ \\
\hline $\begin{array}{l}\text { Hood } \\
\text { North TMP }\end{array}$ & $\begin{array}{l}\text { Existing } \\
\text { infrastructure }\end{array}$ & & $120 / 240 \mathrm{~V}$ & $20^{\prime}$ trench & $\begin{array}{l}\text { Upgrade } \\
120 \mathrm{~V} \text { outlets } \\
\text { to } 240 \mathrm{~V} \text { for } \\
\text { Level } 2 \text { EVSE }\end{array}$ & $\begin{array}{l}\text { Reconfigure EVSE } \\
\text { dedicating single-phase } 120 \\
\text { V service to } 240 \mathrm{~V} \text { service. }\end{array}$ & $\begin{array}{l}2 \text { dual-port Level } \\
2 \text { pedestal units } \\
\text { (4 ports total) }\end{array}$ \\
\hline
\end{tabular}




\begin{tabular}{|c|c|c|c|c|c|c|c|}
\hline Location & $\begin{array}{l}\text { Electrical } \\
\text { Access Point }\end{array}$ & $\begin{array}{l}\text { Proposed } \\
\text { Transformer }\end{array}$ & $\begin{array}{l}\text { Secondary } \\
\text { Voltage }\end{array}$ & $\begin{array}{l}\text { Electrical } \\
\text { Run }\end{array}$ & $\begin{array}{l}\text { Panel } \\
\text { Upgrades }\end{array}$ & $\begin{array}{l}\text { Recommended Concept } \\
\text { Design }\end{array}$ & $\begin{array}{l}\text { EVSE Type and } \\
\text { Quantity }\end{array}$ \\
\hline $\begin{array}{l}\text { Hunter } \\
\text { Liggett } \\
\text { Building } 290\end{array}$ & $\begin{array}{l}\text { Existing } \\
\text { subpanel }\end{array}$ & $\begin{array}{l}\text { Existing } \\
\text { transformer } \\
\text { that feeds } \\
\text { Building } 290\end{array}$ & $208 / 120 \mathrm{~V}$ & 40' trench & $\begin{array}{l}\text { Upgrade } \\
\text { service panel }\end{array}$ & $\begin{array}{l}\text { Investigate using existing } \\
\text { conduit from utility pole to } \\
\text { Building } 290 \text {. }\end{array}$ & $\begin{array}{l}1 \text { dual-port and } 1 \\
\text { single-port Level } \\
2 \text { pedestal unit ( } 3 \\
\text { ports total) }\end{array}$ \\
\hline $\begin{array}{l}\text { Hunter } \\
\text { Liggett } \\
\text { IHG Hotel }\end{array}$ & & $\begin{array}{l}\text { Existing } \\
\text { transformer } \\
\text { that feeds } \\
\text { IHG Hotel }\end{array}$ & & 60 ' trench & $\begin{array}{l}\text { Install new } \\
200 A \\
\text { subpanel }\end{array}$ & $\begin{array}{l}\text { Tiger Team was not able to } \\
\text { gain access to electrical } \\
\text { rooms; the EVSE at IHG } \\
\text { Hotel can also be used to } \\
\text { serve the Hacienda. }\end{array}$ & $\begin{array}{l}2 \text { dual-port Level } \\
2 \text { pedestal units } \\
\text { (4 ports total) }\end{array}$ \\
\hline $\begin{array}{l}\text { Hunter } \\
\text { Liggett } \\
\text { Building } \\
320 \mathrm{C}\end{array}$ & $\begin{array}{l}\text { Either/or } \\
\text { electrical panel } \\
\text { CP or LP }\end{array}$ & $\begin{array}{l}\text { Existing } \\
\text { transformer } \\
\text { that feeds } \\
\text { Building } \\
\text { 320C }\end{array}$ & $208 / 120 \mathrm{~V}$ & $110^{\prime}$ trench & $\begin{array}{l}\text { New } 200 \text { A } \\
\text { subpanel }\end{array}$ & $\begin{array}{l}\text { Use the spare } 20 \text {-amp } \\
\text { breakers in either/both the } \\
208 \mathrm{~V} \text { panels labeled as CP } \\
\text { or LP; the spare single-pole } \\
20 \text {-amp breakers will need } \\
\text { to be replaced with double- } \\
\text { pole } 40 \text {-amp breakers. }\end{array}$ & $\begin{array}{l}2 \text { dual-port Level } \\
2 \text { pedestal units } \\
\text { (4 ports total) }\end{array}$ \\
\hline $\begin{array}{l}\text { Jackson } \\
\text { Building } \\
2606 \text { TMP }\end{array}$ & $\begin{array}{l}\text { Exterior - east } \\
\text { side of building }\end{array}$ & & $208 / 120 \mathrm{~V}$ & $40^{\prime}$ trench & New subpanel & $\begin{array}{l}\text { Install exterior panel, and } \\
\text { electrical run under asphalt } \\
\text { and grass. }\end{array}$ & $\begin{array}{l}6 \text { dual-port Level } \\
2 \text { pedestal units } \\
(12 \text { ports total) }\end{array}$ \\
\hline $\begin{array}{l}\text { Knox } \\
\text { Building } 482 \\
\text { TMP }\end{array}$ & & & & & New subpanel & $\begin{array}{l}\text { Install new exterior } \\
\text { subpanel, meter, and } \\
\text { pedestal EVSE; use existing } \\
\text { electrical trench if possible. }\end{array}$ & $\begin{array}{l}8 \text { dual-port Level } \\
2 \text { pedestal units } \\
(16 \text { ports total) }\end{array}$ \\
\hline $\begin{array}{l}\text { Leavenworth } \\
\text { Building } 687 \\
\text { TMP }\end{array}$ & $\begin{array}{l}\text { Interior - } \\
\text { distribution } \\
\text { service panel }\end{array}$ & $3 \times 100$ kVA & $120 / 240 \mathrm{~V}$ & 150' conduit & $\begin{array}{l}\text { Upgrade to } \\
400 \text { A main } \\
\text { distribution } \\
\text { panel }\end{array}$ & $\begin{array}{l}\text { Add three dual-port EVSE } \\
\text { wall units for a total of six } \\
\text { charging ports. }\end{array}$ & $\begin{array}{l}3 \text { dual-port Level } \\
2 \text { wall-mount } \\
\text { units ( } 6 \text { ports } \\
\text { total) }\end{array}$ \\
\hline $\begin{array}{l}\text { Leonard } \\
\text { Wood } \\
\text { TMP }\end{array}$ & $\begin{array}{l}\text { South-southeast } \\
\text { of TMP main } \\
\text { office }\end{array}$ & 150 kVA & $208 / 120$ V & $\begin{array}{l}250 ' \\
\text { overhead } \\
50 \text { ' trench }\end{array}$ & & $\begin{array}{l}\text { Connect exiting line with } \\
\text { underground electrical run } \\
\text { through boring and trenching } \\
\text { under asphalt to meter, } \\
\text { subpanel, and EVSE unit. }\end{array}$ & $\begin{array}{l}4 \text { dual-port Level } \\
2 \text { pedestal units } \\
\text { (8 ports total) }\end{array}$ \\
\hline
\end{tabular}




\begin{tabular}{|c|c|c|c|c|c|c|c|}
\hline Location & $\begin{array}{l}\text { Electrical } \\
\text { Access Point }\end{array}$ & $\begin{array}{l}\text { Proposed } \\
\text { Transformer }\end{array}$ & $\begin{array}{l}\text { Secondary } \\
\text { Voltage }\end{array}$ & $\begin{array}{l}\text { Electrical } \\
\text { Run }\end{array}$ & $\begin{array}{l}\text { Panel } \\
\text { Upgrades }\end{array}$ & $\begin{array}{l}\text { Recommended Concept } \\
\text { Design }\end{array}$ & $\begin{array}{l}\text { EVSE Type and } \\
\text { Quantity }\end{array}$ \\
\hline $\begin{array}{l}\text { Lewis } \\
\text { McChord } \\
\text { Old TMP } \\
\text { Yard }\end{array}$ & $\begin{array}{l}\text { South of } \\
\text { Building } 9522\end{array}$ & $\begin{array}{l}\text { New } \\
\text { transformer } \\
\text { mounted on } \\
\text { new electric } \\
\text { pole east of } \\
\text { Building } \\
9522\end{array}$ & $208 / 120 \mathrm{~V}$ & $\begin{array}{l}100^{\prime} \\
\text { overhead 60' } \\
\text { trench }\end{array}$ & $\begin{array}{l}\text { New } 200 \text { A } \\
\text { subpanel }\end{array}$ & $\begin{array}{l}\text { Tie into electric pole } \\
\text { (M3P35A) south of Building } \\
9522, \text { install secondary } \\
\text { conductor to upgraded 50' } \\
\text { class } 2 \text { electric pole east of } \\
\text { Building } 9522 \text { and run } \\
\text { conductors underground for } \\
60 \text { ' to the old TMP yard. }\end{array}$ & $\begin{array}{l}3 \text { dual-port Level } \\
2 \text { pedestal units } \\
(6 \text { ports total) }\end{array}$ \\
\hline \multirow{2}{*}{$\begin{array}{l}\text { McCoy } \\
\text { TMP at } \\
\text { Buildings } \\
1884 \text { and } \\
1887\end{array}$} & $\begin{array}{l}\text { Exterior - } \\
\text { Distribution } \\
\text { Transformer }\end{array}$ & & $120 / 240 \mathrm{~V}$ & 150 ' trench & $\begin{array}{l}\text { New } 600 \mathrm{~A} \\
\text { service panel }\end{array}$ & $\begin{array}{l}\text { Add five dual-port EVSE } \\
\text { pedestal units for a total of } \\
\text { ten charging ports. }\end{array}$ & $\begin{array}{l}5 \text { dual-port Level } \\
2 \text { pedestal units } \\
\text { (10 ports total) }\end{array}$ \\
\hline & $\begin{array}{l}\text { New service } \\
\text { installation }\end{array}$ & & & & & $\begin{array}{l}\text { Add three "make ready" } \\
\text { stubs for potential growth of } \\
\text { five ports. }\end{array}$ & \\
\hline $\begin{array}{l}\text { Monterey } \\
\text { Building } 220 \\
\text { TMP lot } 27\end{array}$ & $\begin{array}{l}\text { Southeast } \\
\text { corner of } \\
\text { Infantry St and } \\
\text { Ft Mervine PI }\end{array}$ & 50 kVA & $120 / 240 \mathrm{~V}$ & 60 'trench & $\begin{array}{l}\text { New } 200 \text { A } \\
\text { subpanel and } \\
\text { meter }\end{array}$ & $\begin{array}{l}\text { Add two dual-port EVSE } \\
\text { pedestal units for a total of } 4 \\
\text { charging ports. }\end{array}$ & $\begin{array}{l}2 \text { dual-port Level } \\
2 \text { pedestal units } \\
\text { (4 ports total) }\end{array}$ \\
\hline $\begin{array}{l}\text { Monterey } \\
\text { Building } 517 \\
\text { lot } 89\end{array}$ & $\begin{array}{l}\text { Service panel in } \\
\text { Lot } 89\end{array}$ & $\begin{array}{l}\text { Existing } \\
\text { transformer }\end{array}$ & $\begin{array}{l}208 / 120 \mathrm{~V} \\
\text { or } \\
120 / 240 \mathrm{~V}\end{array}$ & & $\begin{array}{l}\text { Upgrade } \\
\text { single-pole to } \\
\text { double-pole } \\
\text { breakers }\end{array}$ & $\begin{array}{l}\text { Investigate use of existing } \\
\text { conduit and conductors for } \\
\text { new Level } 2 \text { EVSE. }\end{array}$ & $\begin{array}{l}4 \text { single-port } \\
\text { Level } 2 \text { pedestal } \\
\text { units ( } 4 \text { ports } \\
\text { total) }\end{array}$ \\
\hline $\begin{array}{l}\text { Monterey } \\
\text { Building } \\
622 \mathrm{~A} \text { lot } 80\end{array}$ & $\begin{array}{l}\text { Subpanel in } \\
\text { Building } 622 \mathrm{~A}\end{array}$ & $\begin{array}{l}\text { Existing } \\
\text { transformer } \\
\text { that feeds } \\
\text { Building } \\
622 \mathrm{~A}\end{array}$ & $\begin{array}{l}208 / 120 \mathrm{~V} \\
\text { or } \\
120 / 240 \mathrm{~V}\end{array}$ & 18' trench & $\begin{array}{l}\text { New } 200 \text { A } \\
\text { subpanel }\end{array}$ & $\begin{array}{l}\text { Add one dual-port EVSE } \\
\text { pedestal unit for a total of } 2 \\
\text { charging ports. }\end{array}$ & $\begin{array}{l}1 \text { dual-port Level } \\
2 \text { pedestal unit }(2 \\
\text { ports total) }\end{array}$ \\
\hline $\begin{array}{l}\text { Monterey } \\
\text { Building } \\
4463 \text { OMC }\end{array}$ & $\begin{array}{l}\text { New } 200 \text { A } \\
\text { subpanel }\end{array}$ & $\begin{array}{l}\text { Existing } \\
\text { transformer } \\
\text { that feeds } \\
\text { Building } \\
4463\end{array}$ & $\begin{array}{l}208 / 120 \mathrm{~V} \\
\text { or } \\
120 / 240 \mathrm{~V}\end{array}$ & $\begin{array}{l}30^{\prime} \text { conduit } \\
35^{\prime} \text { trench }\end{array}$ & $\begin{array}{l}\text { New } 200 \text { A } \\
\text { subpanel }\end{array}$ & $\begin{array}{l}\text { Add two dual-port EVSE } \\
\text { pedestal units for a total of } 4 \\
\text { charging ports. }\end{array}$ & $\begin{array}{l}2 \text { dual-port Level } \\
2 \text { pedestal units } \\
\text { (4 ports total) }\end{array}$ \\
\hline
\end{tabular}




\begin{tabular}{|c|c|c|c|c|c|c|c|}
\hline Location & $\begin{array}{l}\text { Electrical } \\
\text { Access Point }\end{array}$ & $\begin{array}{l}\text { Proposed } \\
\text { Transformer }\end{array}$ & $\begin{array}{l}\text { Secondary } \\
\text { Voltage }\end{array}$ & $\begin{array}{l}\text { Electrical } \\
\text { Run }\end{array}$ & $\begin{array}{l}\text { Panel } \\
\text { Upgrades }\end{array}$ & $\begin{array}{l}\text { Recommended Concept } \\
\text { Design }\end{array}$ & $\begin{array}{l}\text { EVSE Type and } \\
\text { Quantity }\end{array}$ \\
\hline $\begin{array}{l}\text { Myer- } \\
\text { Henderson } \\
\text { Building } 205\end{array}$ & $\begin{array}{l}\text { Exterior: near } \\
\text { corner of } \\
\text { building }\end{array}$ & 150 kVA & $208 / 120 \mathrm{~V}$ & & $\begin{array}{l}\text { New exterior } \\
\text { subpanel }\end{array}$ & $\begin{array}{l}\text { Install exterior panel from } \\
\text { outside transformer with } \\
\text { electrical run under } \\
\text { landscaping and sidewalk to } \\
\text { parking spot. }\end{array}$ & $\begin{array}{l}1 \text { dual-port Level } \\
2 \text { pedestal unit }(2 \\
\text { ports total) }\end{array}$ \\
\hline $\begin{array}{l}\text { Myer- } \\
\text { Henderson } \\
\text { Building } 59\end{array}$ & $\begin{array}{l}\text { Exterior: across } \\
\text { the parking area }\end{array}$ & 150 kVA & $208 / 120 \mathrm{~V}$ & & $\begin{array}{l}\text { New exterior } \\
\text { subpanel }\end{array}$ & $\begin{array}{l}\text { Install exterior panel from } \\
\text { outside transformer with } \\
\text { electrical run under } \\
\text { landscaping to parking spot. }\end{array}$ & $\begin{array}{l}1 \text { dual-port Level } \\
2 \text { pedestal units } \\
(2 \text { ports total) }\end{array}$ \\
\hline $\begin{array}{l}\text { Polk } \\
\text { TMP Carport } \\
\text { at Buildings } \\
3415,351 \text {, or } \\
4915\end{array}$ & $\begin{array}{l}\text { PV system } \\
\text { service panel }\end{array}$ & & $208 / 120 \mathrm{~V}$ & 15' overhead & New subpanel & $\begin{array}{l}\text { Upgrade existing Level } 1 \\
\text { wall outlet with dual-port } \\
\text { Level } 2 \text { EVSE on the steel } \\
\text { structure of the carport. }\end{array}$ & $\begin{array}{l}1 \text { dual-port Level } \\
2 \text { wall-mount unit } \\
\text { ( } 2 \text { ports total) }\end{array}$ \\
\hline $\begin{array}{l}\text { Redstone } \\
\text { Building } \\
3664 \text { TMP }\end{array}$ & $\begin{array}{l}\text { Electric pole } \\
360259 \text { in TMP }\end{array}$ & 150 kVA & $120 / 240 \mathrm{~V}$ & 50 ' trench & $\begin{array}{l}\text { New } 400 \mathrm{~A} \\
\text { service panel }\end{array}$ & $\begin{array}{l}\text { Install new transformer and } \\
\text { electric service east of } \\
\text { Building } 3664 \text { near the } \\
\text { existing C-Pool parking } \\
\text { location. Install EVSE in } \\
\text { existing asphalt at edge of } \\
\text { parking lot. }\end{array}$ & $\begin{array}{l}5 \text { dual-port Level } \\
2 \text { pedestal units } \\
\text { (10 ports total) }\end{array}$ \\
\hline $\begin{array}{l}\text { Riley } \\
\text { Building } 375 \\
\text { TMP }\end{array}$ & $\begin{array}{l}\text { Electric pole } \\
\text { northeast of } \\
\text { Building } 375\end{array}$ & $3 \times 100$ kVA & $208 / 120 \mathrm{~V}$ & 50 ' trench & $\begin{array}{l}\text { New service } \\
\text { panel }\end{array}$ & $\begin{array}{l}\text { Install new service panel, } \\
\text { meter, and EVSE. }\end{array}$ & $\begin{array}{l}5 \text { dual-port Level } \\
2 \text { pedestal units } \\
\text { (10 ports total) }\end{array}$ \\
\hline $\begin{array}{l}\text { Riley } \\
\text { Open lot } \\
\text { near TMP }\end{array}$ & $\begin{array}{l}\text { Electric pole } \\
\text { northeast of } \\
\text { Building } 375\end{array}$ & $3 \times 100$ kVA & $208 / 120 \mathrm{~V}$ & 50 ' trench & $\begin{array}{l}\text { New service } \\
\text { panel }\end{array}$ & $\begin{array}{l}\text { Install new service panel, } \\
\text { meter, and EVSE. }\end{array}$ & $\begin{array}{l}5 \text { dual-port Level } \\
2 \text { pedestal units } \\
\text { (10 ports total) }\end{array}$ \\
\hline $\begin{array}{l}\text { Rucker } \\
\text { TMP }\end{array}$ & $\begin{array}{l}\text { Main distribution } \\
\text { panel at Building } \\
1426\end{array}$ & & $208 / 120 \mathrm{~V}$ & 120' conduit & $\begin{array}{l}\text { New } 250 \text { A } \\
\text { subpanel }\end{array}$ & $\begin{array}{l}\text { Install subpanel off main } \\
\text { distribution panel and run } \\
\text { conduit to the proposed } \\
\text { EVSE location. }\end{array}$ & $\begin{array}{l}3 \text { dual-port Level } \\
2 \text { wall-mount } \\
\text { units ( } 6 \text { ports } \\
\text { total) }\end{array}$ \\
\hline
\end{tabular}




\begin{tabular}{|c|c|c|c|c|c|c|c|}
\hline Location & $\begin{array}{l}\text { Electrical } \\
\text { Access Point }\end{array}$ & $\begin{array}{l}\text { Proposed } \\
\text { Transformer }\end{array}$ & $\begin{array}{l}\text { Secondary } \\
\text { Voltage }\end{array}$ & $\begin{array}{l}\text { Electrical } \\
\text { Run }\end{array}$ & $\begin{array}{l}\text { Panel } \\
\text { Upgrades }\end{array}$ & $\begin{array}{l}\text { Recommended Concept } \\
\text { Design }\end{array}$ & $\begin{array}{l}\text { EVSE Type and } \\
\text { Quantity }\end{array}$ \\
\hline $\begin{array}{l}\text { Sill } \\
\text { Buildings } \\
2282 \text { and } \\
2283 \text { LRC }\end{array}$ & $\begin{array}{l}\text { LRC inner } \\
\text { compound }\end{array}$ & & $208 / 120 \mathrm{~V}$ & & $\begin{array}{l}\text { Upgrade } \\
\text { service panel }\end{array}$ & $\begin{array}{l}\text { Install EVSE in the LRC } \\
\text { inner compound between } \\
\text { Buildings } 2282 \text { and } 2283 \text {. }\end{array}$ & $\begin{array}{l}1 \text { dual-port Level } \\
2 \text { pedestal unit }(2 \\
\text { ports total) }\end{array}$ \\
\hline $\begin{array}{l}\text { Sill } \\
\text { Building } \\
2026 \text { TMP }\end{array}$ & $\begin{array}{l}\text { In front of } \\
\text { Building } 1945\end{array}$ & & $208 / 120 \mathrm{~V}$ & & $\begin{array}{l}\text { Upgrade } \\
\text { service panel }\end{array}$ & $\begin{array}{l}\text { Install EVSE in the TMP } \\
\text { located in front of Building } \\
\text { 1945, the dispatch office. }\end{array}$ & $\begin{array}{l}2 \text { dual-port Level } \\
2 \text { pedestal units } \\
\text { (4 ports total) }\end{array}$ \\
\hline $\begin{array}{l}\text { White Sands } \\
\text { TMP }\end{array}$ & $\begin{array}{l}\text { Existing service } \\
\text { south of TMP }\end{array}$ & & $208 / 120 \mathrm{~V}$ & $\begin{array}{l}80 \text { ' overhead } \\
10 \text { ' trench }\end{array}$ & $\begin{array}{l}\text { New } 400 \mathrm{~A} \\
\text { subpanel }\end{array}$ & $\begin{array}{l}\text { Install three utility poles with } \\
\text { electrical run overhead and } \\
\text { under asphalt to meter, sub } \\
\text { panel and EVSE. }\end{array}$ & $\begin{array}{l}2 \text { dual-port Level } \\
2 \text { pedestal units } \\
\text { (4 ports total) }\end{array}$ \\
\hline $\begin{array}{l}\text { White Sands } \\
\text { Building } 102 \\
\text { parking lot }\end{array}$ & $\begin{array}{l}\text { Existing service } \\
\text { panel }\end{array}$ & & $120 / 240 \mathrm{~V}$ & $10^{\prime}$ trench & $\begin{array}{l}\text { Upgrade } \\
\text { service panel }\end{array}$ & $\begin{array}{l}\text { Connect to existing panel } \\
\text { with electrical run under } \\
\text { gravel to meter, sub panel } \\
\text { and EVSE. }\end{array}$ & $\begin{array}{l}1 \text { dual-port Level } \\
2 \text { pedestal type }\end{array}$ \\
\hline
\end{tabular}

